Portland State University

PDXScholar

6-3-1993

\title{
A Limnological Analysis of Ten Mountain Lakes
}

Gary Wayne Burns

Portland State University

Follow this and additional works at: https://pdxscholar.library.pdx.edu/open_access_etds

Part of the Biology Commons

Let us know how access to this document benefits you.

\section{Recommended Citation}

Burns, Gary Wayne, "A Limnological Analysis of Ten Mountain Lakes" (1993). Dissertations and Theses.

Paper 4524.

https://doi.org/10.15760/etd.6408

This Thesis is brought to you for free and open access. It has been accepted for inclusion in Dissertations and Theses by an authorized administrator of PDXScholar. Please contact us if we can make this document more accessible: pdxscholar@pdx.edu. 
AN ABSTRACT OF THE THESIS OF GARY WAYNE BURNS for the Masters of Science in Biology presented June 3,1993.

Title: A Limnological Analysis of Ten Mountain Lakes. APPROVED BY THE MEMBERS OF THE THESIS COMMITTEE:

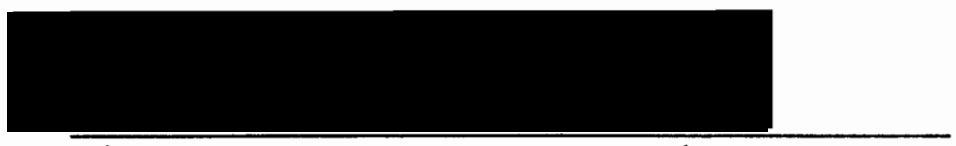

Richard R. Petersen, Chair

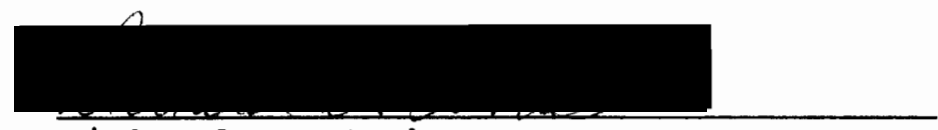

Richard B. Forbes
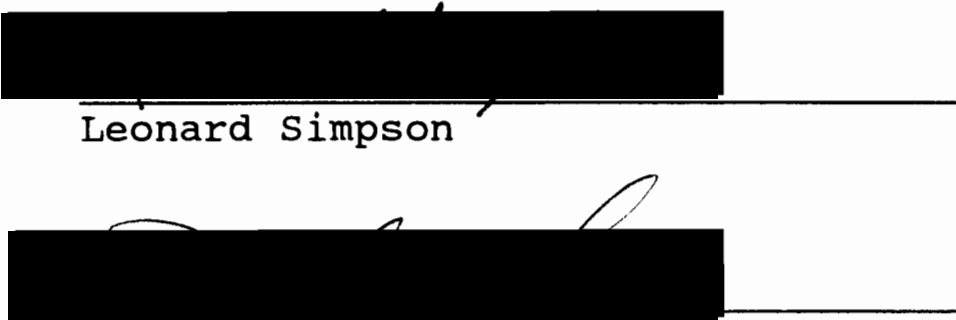

Daniel M. Johnson

Ten mountain lakes were analyzed in order that they be assigned a trophic status. The lakes which are located in the Mount Hood National Forest of Oregon are Anvil, Beaver Pond, Cripple Creek, Fish, Gifford, Monon, Ollalie, Rimrock, Round, and sportsman. The purpose of this report is to determine the productivity of these waters.

Data were collected for analyses of temperature, dissolved oxygen concentration, secchi depth, major ion 
concentration, light intensity versus depth, alkalinity, phytoplankton species composition/total density, and zooplankton species composition/total density.

Samples were collected in Van Dorn sampling bottles and returned to the laboratory for chemical analyses and taxonomic identification of biological organisms. Field profiles were taken for light intensity, temperature, dissolved oxygen concentration, specific conductivity, and depth using portable electronic equipment. A Secchi disk was used in the field for obtaining light extinction data.

The lakes were assigned a trophic status according to Carlson's Trophic State Index (Carlson, 1977).

Beaver Pond Lake which is the most productive lake of the 10 surveyed had an average secchi depth of 1.7 meters, an average soluble reactive phosphorous concentration of 59.8 $\mathrm{ug} / \mathrm{L}$, and an average chlorophyll-a concentration of $29.3 \mathrm{ug} / \mathrm{L}$ for the dates sampled. These values are consistent with lakes which are eutrophic.

Ollalie Lake had an average Secchi depth of 13.2 meters, an average soluble reactive phosphorous concentration of 1.64 $\mathrm{ug} / \mathrm{L}$, and an average chlorophyll-a concentration of $0.28 \mathrm{ug} / \mathrm{L}$. This lake is ultraoligotrophic-to-oligotrophic according to the Carlson index. The other lakes of the study were assigned values for trophic state which are somewhere between those assigned to Beaver Pond and ollalie lakes.

The 10 lakes studied for this report were compared to 
lakes studied for the compilation of the Western Lake Survey (Landers, et. al. 1987). It was noted that Beaver Pond, Round, and sportsman lakes are nutrient rich while Monon, ollalie, and Gifford, are nutrient poor when compared to other lakes located in the Pacific Northwest. Anvil, Cripple Creek, Fish, and Rimrock lakes have profiles consistent with the majority of mountain lakes located in the area. 
A LIMNOLOGICAL ANALYSIS OF TEN MOUNTAIN LAKES

by

GARY WAYNE BURNS

A thesis submitted in partial fulfillment of the requirements for the degree of

\author{
MASTER OF SCIENCE \\ in \\ BIOLOGY
}

Portland state University

1993 
TO THE OFFICE OF GRADUATE STUDIES:

The members of the Committee approve the thesis of Gary Wayne Burns presented June 3, 1993.

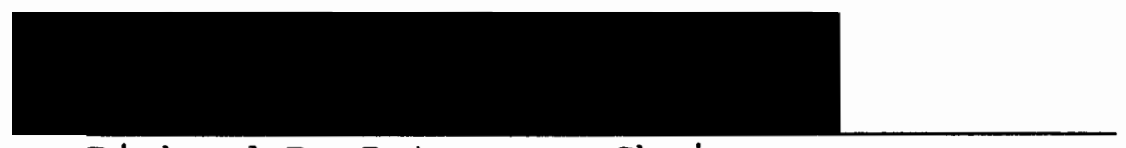

Richard R. Petersen, Chair
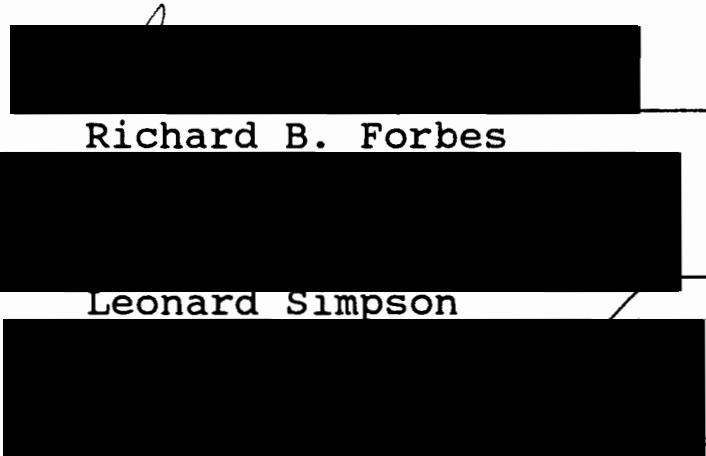

Daniel MrJonnson

APPROVED :

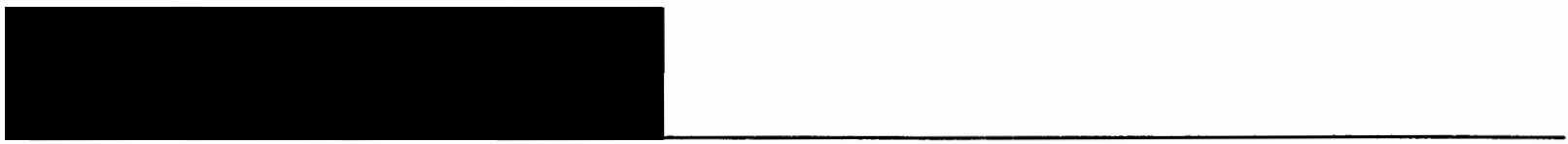

Richard B. Forbes, Chair, Department of Biology

Roy W. Koch, Vice Provost for Graduate Studies and Research 
DEDICATION

This thesis is dedicated to my wife. 


\section{ACKNOWLEDGEMENTS}

I would like to acknowledge the U.S. Forest service for the research funding which made this project possible.

I would especially like to thank Robert Deibel for his assistance during the early stages of the project.

I would also like to thank my son Jonathan for his help in the field, Vic Menting for his help in the lab, and Allan Vogel, and Jim sweet for their counsel.

Finally, I would like to thank Dr. Richard Petersen for his support, motivation, and assistance throughout each phase of the project. 
TABLE OF CONTENTS

PAGE

ACKNOWLEDGEMENTS.......................... . . . .

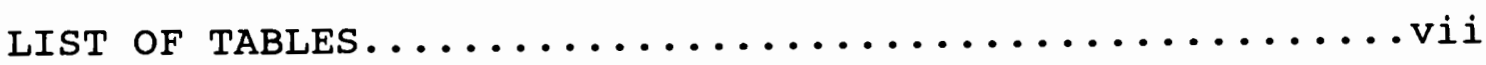

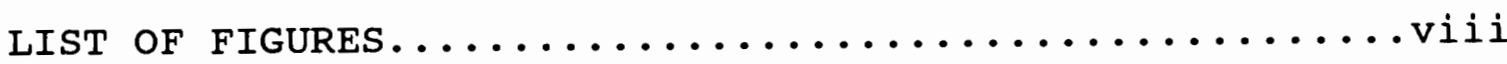

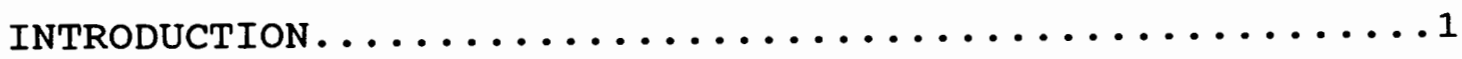

Anvil Lake............................

Beaver Pond Lake.......................

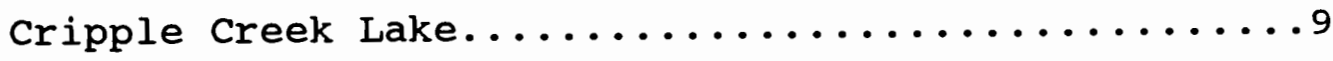

Fish Lake................................

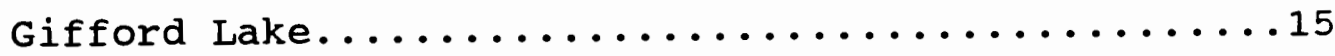

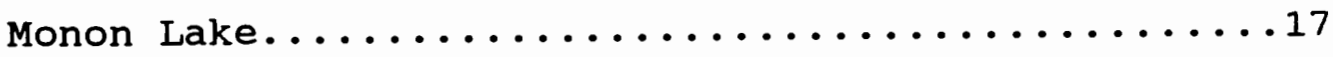

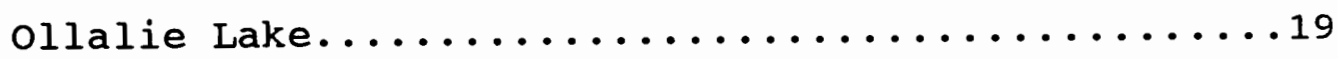

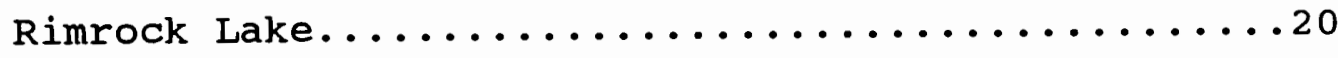

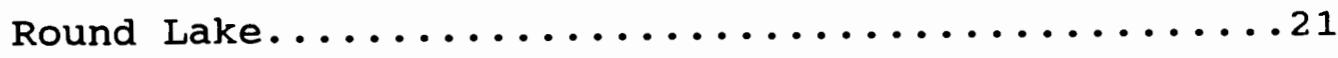

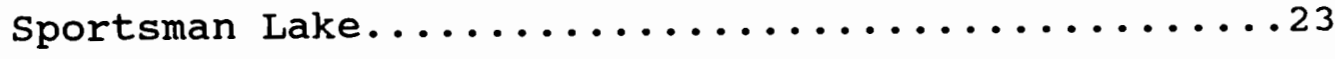

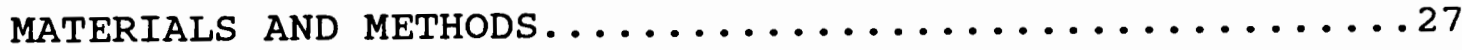

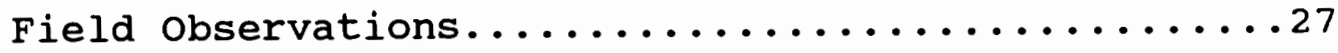

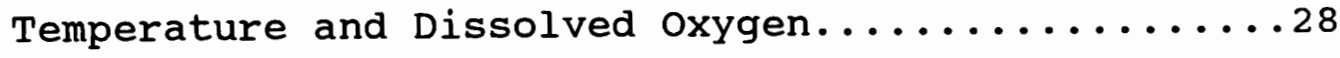

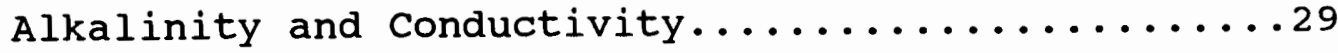

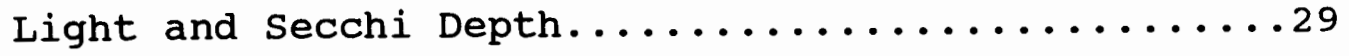

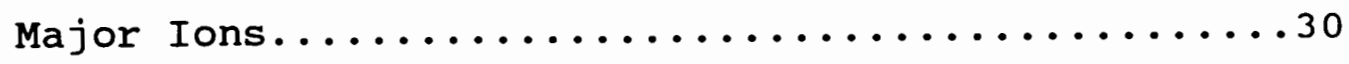

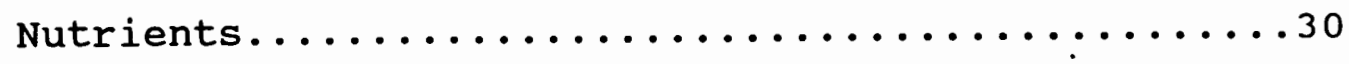




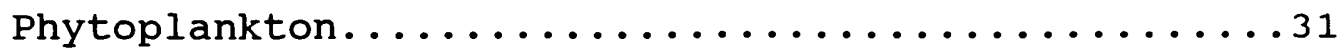

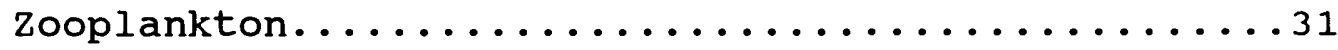

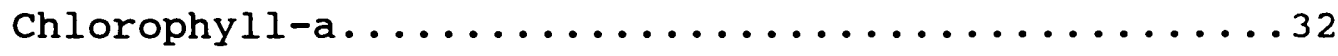

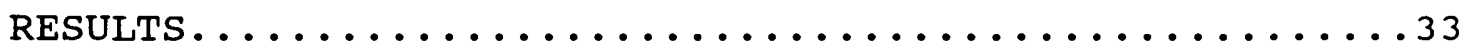

Temperature and Dissolved oxygen..............33 Water Transparency: Light Intensity and Secchi

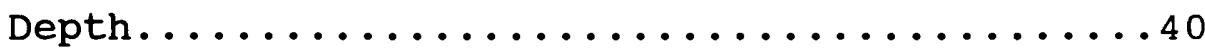

Nutrients.......................... 50

Major Ions, Conductivity, and Alkalinity........54

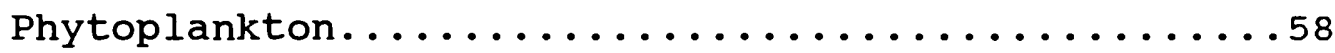

Chlorophyll........................60

zooplankton........................62

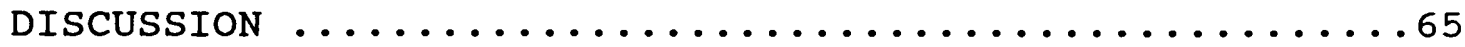

Physical Characteristics and Morphology........65

Temperature.......................67

Dissolved oxygen....................67

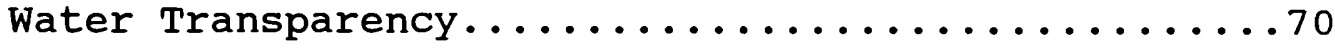

Nutrients...........................

Nitrogen

Phosphorus

Nitrogen and Phosphorus Limitation

Silica

Conductivity........................ 75

Salinity

Cations

Anions

Carbonates and Bicarbonates

Alkalinity $\ldots \ldots \ldots \ldots \ldots \ldots \ldots \ldots \ldots \ldots \ldots$

Phytoplankton....................... 79 
Indicator species

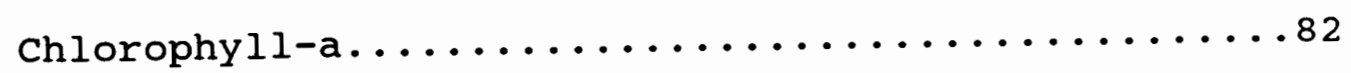

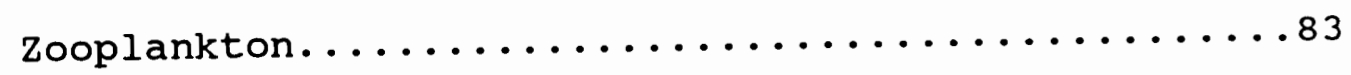

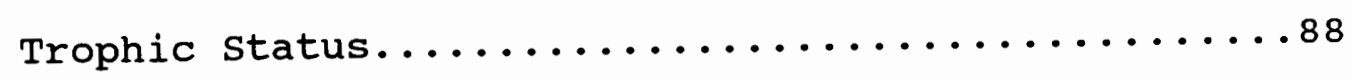

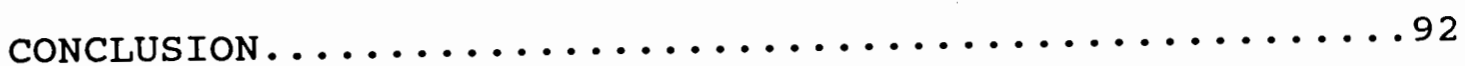

REFERENCES. .........................

APPENDICES

A DETAiled diREctions into EACH LAKE..........95

B TEMPERATURE AND DISSOLVED OXYGEN DATA........101

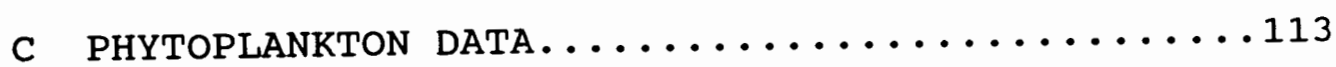

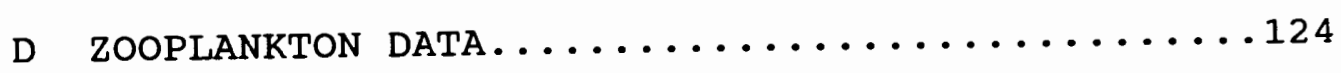




\section{LIST OF TABLES}

TABLE

PAGE

I $\quad$ Physical Parameters..................

II Water Transparency Data..................... 49

III Nutrient Data....................... 52

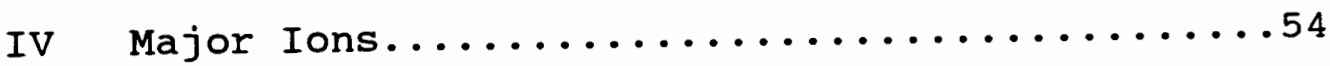

V Conductivity and Alkalinity.............56

VI Chlorophyll-a Concentration.............61 
LIST OF FIGURES

FIGURE

PAGE

1. study area.......................

2. Primary and secondary access routes.........

3. Road and trail system (a), and contours and clearcuts (b), for Anvil Lake......7

4. Sketch map of bathymetry and benthic substrate for Anvil Lake..........8

5. Road and trail system (a), and contours and clearcuts (b), for Beaver Pond

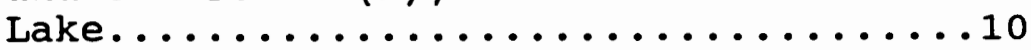

6. Roads, trails, and contours for the cripple Creek Lake drainage basin..........12

7. Sketch map of bathymetry and benthic substrate for Cripple Creek Lake......13

8. Road and trail systems, and contour relief for the Fish Lake, Gifford Lake, and Rimrock Lake drainage basins.

9. Sketch map of approximate bathymetry for Gifford Lake.................18

10. Sketch map of approximate bathymetry for

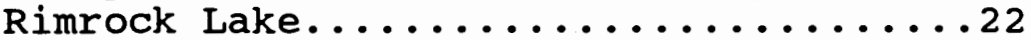

11. Road and trail systems (a), and contours and clearcuts (b), for the Round Lake drainage basin..............24

12. Road and trail systems (a), and contours and clearcuts (b), for the sportsman Lake drainage basin..............25

13. Temperature and dissolved oxygen profiles for Beaver Pond Lake for August 23,

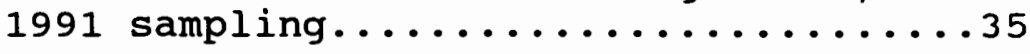


14. Temperature and dissolved oxygen profiles for Beaver Pond Lake for October 25, 1991 sampling................... 36

15. Temperature and dissolved oxygen profiles for Fish Lake for July 1, 1991 sampling...................... 37

16. Temperature and dissolved oxygen profiles for Round Lake for August 24, 1991 sampling.........................

17. Light intensity versus depth for Beaver Pond Lake for October 25, 1991......41

18. Light intensity versus depth for Cripple Creek Lake for July 24, 1992 sampling.....................

19. Light intensity versus depth for Fish Lake for July 1, 1991 sampling.......43

20. Light intensity versus depth for Gifford Lake for August 29, 1991 sampling.....44

21. Light intensity versus depth for Monon Lake for June 29, 1991 sampling......45

22. Light intensity versus depth for ollalie Lake for September 2, 1991 sampling....46

23. Light intensity versus depth for Rimrock Lake for August 30, 1991 sampling.....47

24. Light intensity versus depth for Sportsman Lake for July 25, 1992 sampling......48 


\section{INTRODUCTION}

The ten lakes studied in this investigation are Anvil, Beaver Pond, Cripple Creek, Fish, Gifford, Monon, Ollalie, Rimrock, Round, and Sportsman. These lakes are located within the Cascade mountain range of northwestern oregon, in the southern half of the Mount Hood National Forest (Figure 1). They are located within heavily forested watersheds and range in elevation from $600 \mathrm{~m}$ to over $1500 \mathrm{~m}(2000 \mathrm{f}$ to 5000 f ; TABLE 1).

The district ranger station for the lakes is Ripplebrook Ranger Station, located on oregon state Highway 224 approximately $46.4 \mathrm{kilometers,} \mathrm{(29} \mathrm{mi})$ southeast of Estacada, Clackamas County, oregon (Figure 2). The ranger station is the reference point for the beginning of each access route. Refer to APPENDIX A for detailed directions into each lake.

The purpose of this thesis is twofold. First, it is to describe the physical, chemical, and biological conditions of the lakes and their drainage basins. Second, it is to define a trophic status to each lake according to the system developed by Carlson in 1977.

six of the lakes surveyed for this thesis have not previously been studied. They are Anvil, Beaver Pond, Cripple Creek, Gifford, Rimrock, and Sportsman Lakes. This 


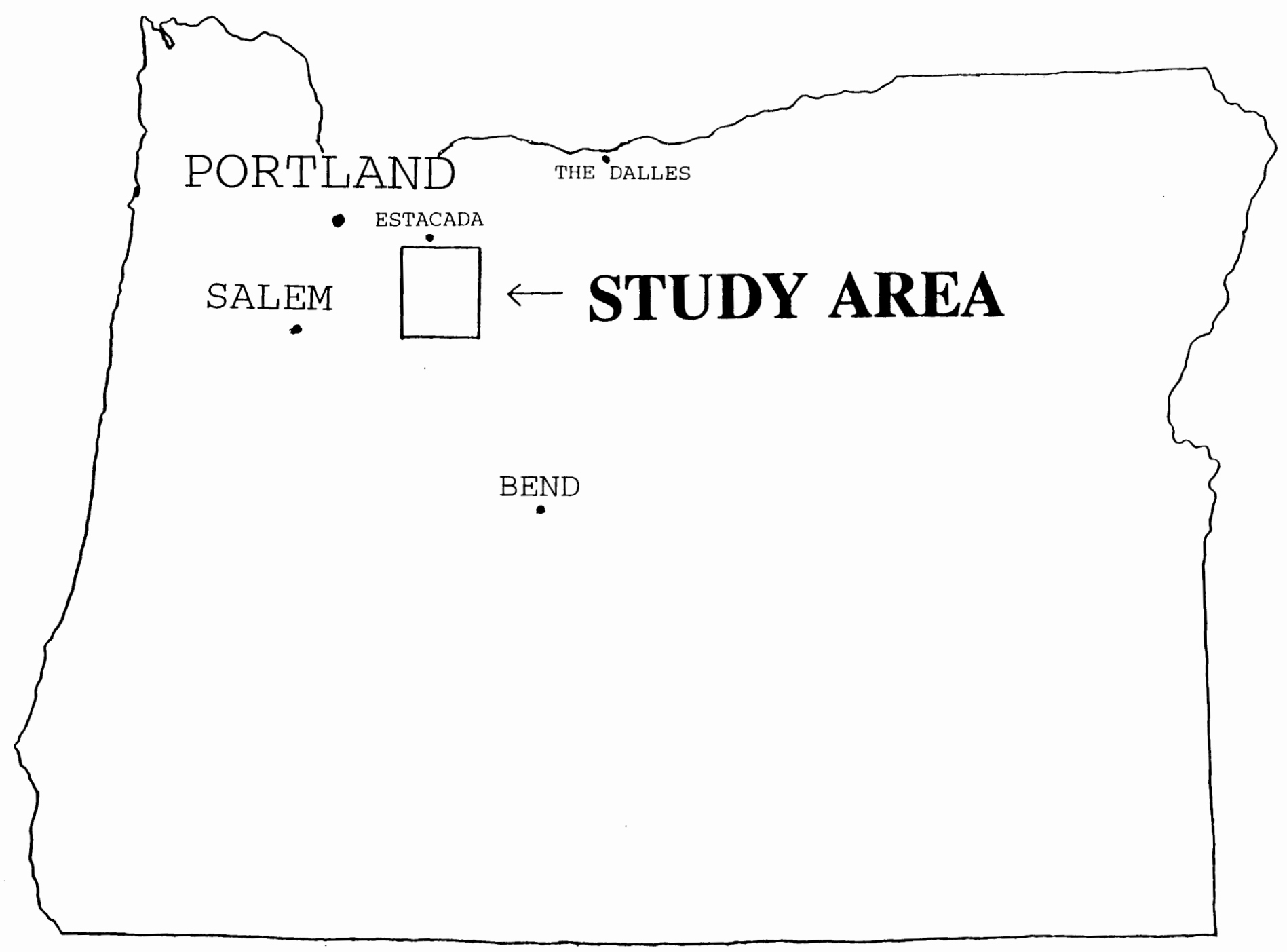

Figure 1. Study area. 


\section{ESTACADA}

田

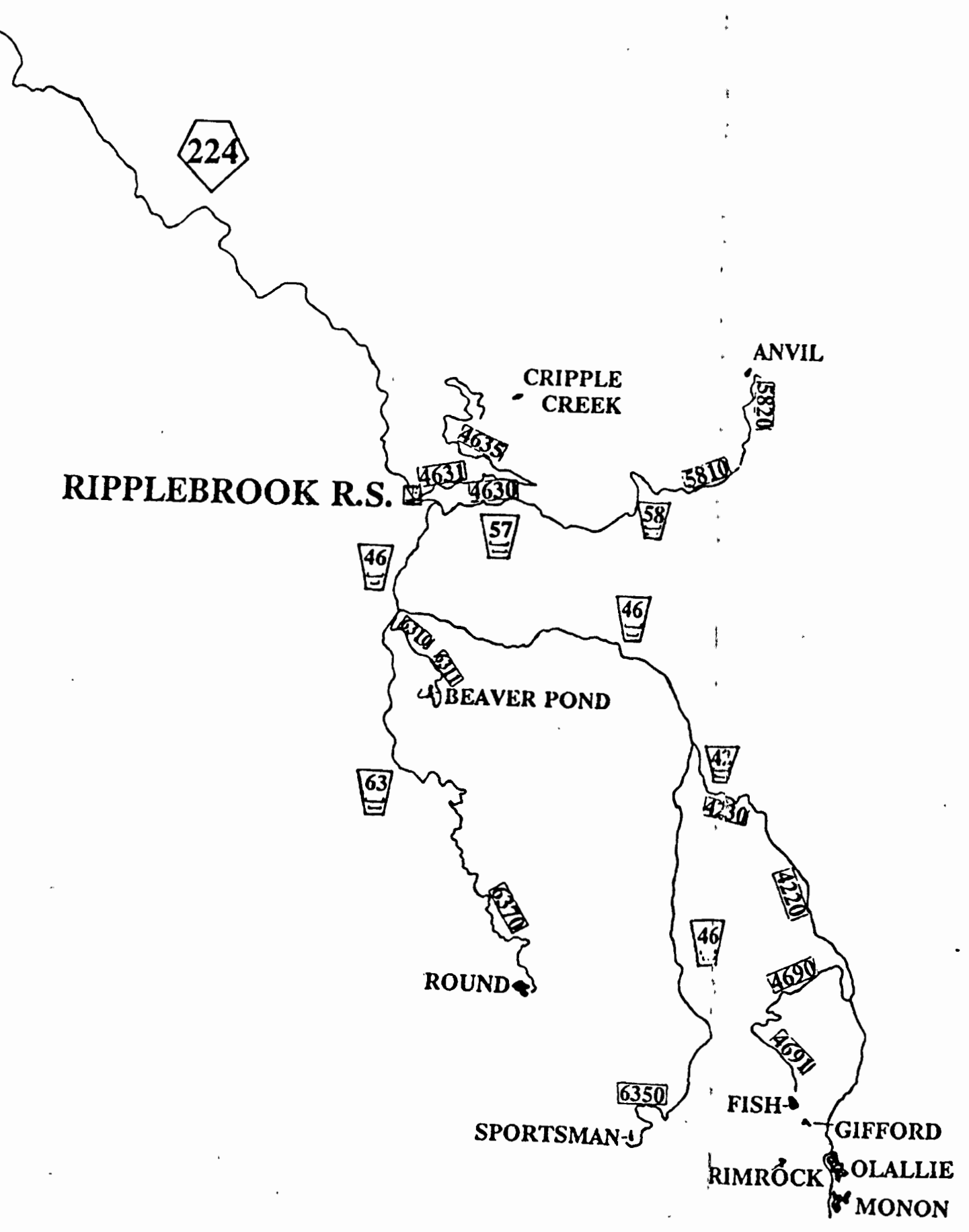

10 SUBALPINE LAKES

Figure 2. Primary and secondary access routes.

\section{MT. HCOD NATIONAL FOREST}

(SOUTH HALF)

OREGON

OREgon STATE highWAY

$\exists$ NATIONAL OREST PRIMARY ROUTE

$\square$ FOREST ROUTE 
TABLE I

PHYSICAL PARAMETERS

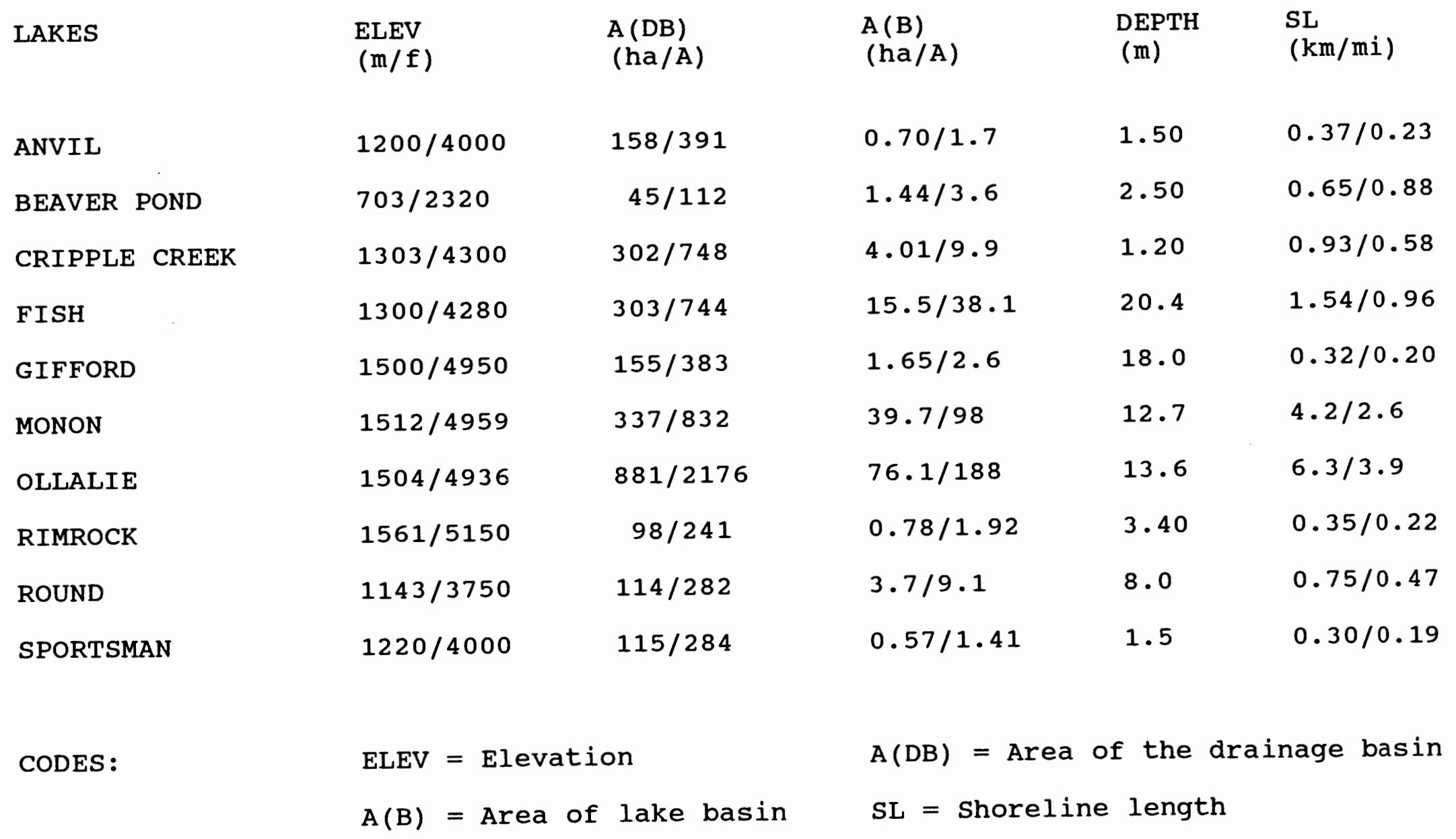


accumulation of baseline data may be of value for future research and/or resource management.

Four of the lakes studied herein have previously been surveyed. They are Fish, Monon, Ollalie, and Round Lakes. The data collected for this study were compared to data obtained during the earlier investigations.

of the four lakes previously studied, Ollalie has been the most often cited. The two most comprehensive studies of this lake were reported in the Atlas of Oregon Lakes (Johnson et. al., 1985) and in a United States Geological Survey open file report (Rinella, 1977). A comparison was made between the data taken during the earlier studies and the data collected for this report (DISCUSSION).

\section{ANVIL LAKE}

Anvil Lake, located approximately $27 \mathrm{~km}$ (17 mi) east from Ripplebrook Ranger station, is shown on the Wolf creek Oregon quadrangle topographic map at T5S, R8E, Sec. 17. Anvil Lake is located within a narrow band of trees and underbrush. There is only one open spot in which to gain lake access. To the south and west outside of the narrow band of vegetation are three clearcut areas. One of the three clearcuts is located just upstream from the lake on the western boundary of the watershed. Only one stream, Anvil creek, flows into and out of Anvil Lake.

Other than the three clearcut areas and the single lake 
access, there is only one obvious impact source within the watershed. USFS trail 724 parallels Anvil Creek to the northeast and at one point crosses a portion of the watershed. There are no campsites, buildings, or boat launches within the watershed (Figure 3), so it is probable that human impact from recreational uses is minimal.

The lake is circular with a saucer-shaped basin. The bottom substrate is primarily silt. It has been heavily invaded by macrophytes (unidentified), and supports a large population of Rough-skinned Newts (Taricha granulosa). Unidentified fish were observed rising during the 1992 sampling. An unidentified waterbird species was also observed on one occasion. A sketch map of the lake bathymetry (Figure 4) was provided by the USGS.

BEAVER POND LAKE

Beaver Pond Lake (referred to as Unnamed Lake by the USFS) is approximately $16 \mathrm{ki}$ (10 $\mathrm{mi})$ south of Ripplebrook Ranger Station. On the United states Geological Survey topographical quadrangle map (Bull of the Woods Quad), it is found at T7S, R6E, Sec. 2 .

Beaver Pond Lake as the name implies is extremely small. It is surrounded on 3 sides by ridges and on a 4 th side is a meadow. The meadow and lake are the remnants of what was once a moderate-size mountain lake.

The northeastern corner of the watershed is clearcut. 

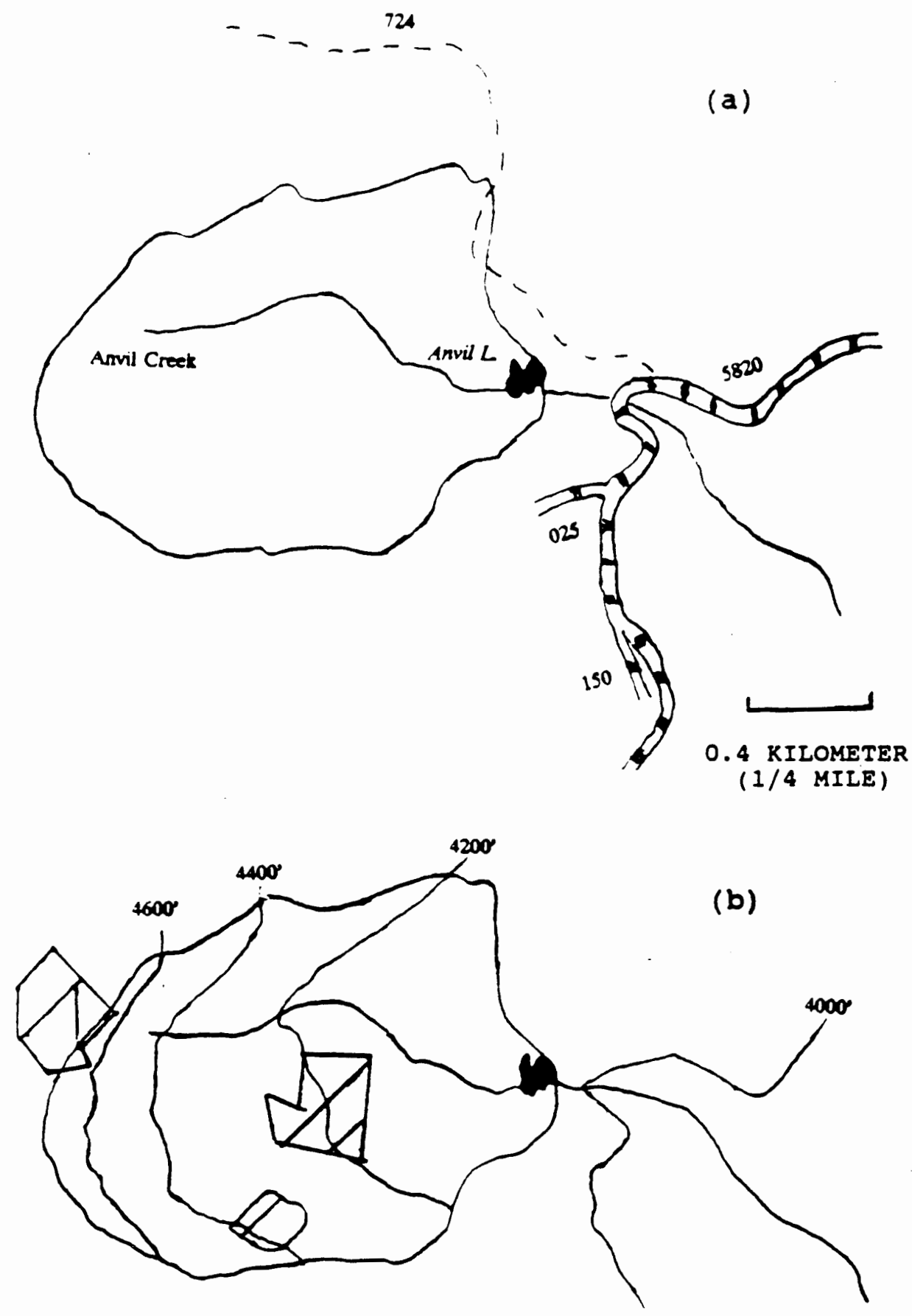

Fiqure 3. Road and trail system (a), and contours and clearcuts (b), for Anvil lake. Clearcuts are designated by hatchlines. 


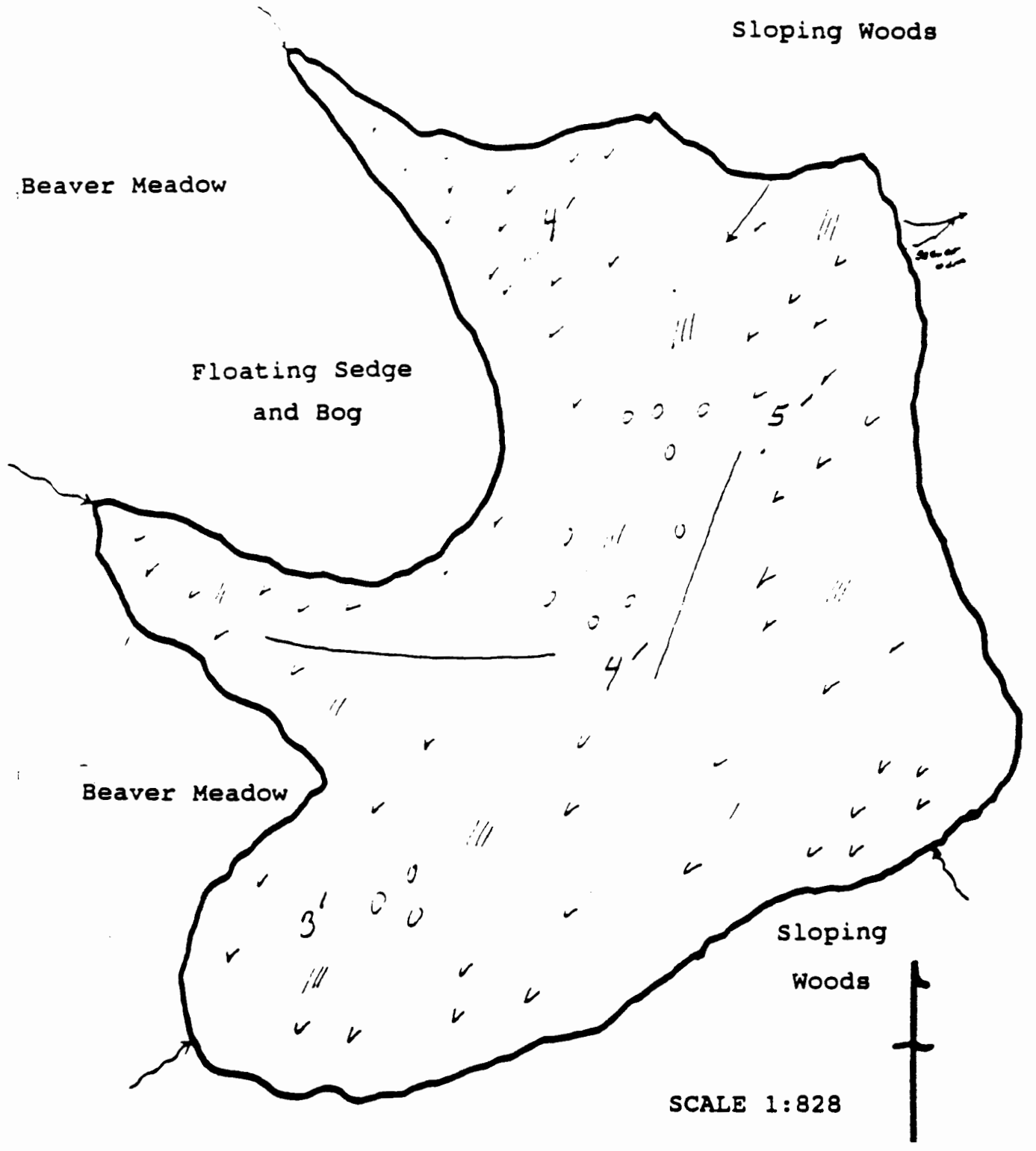

Figure 4. Sketch map of bathymetry and benthic substrate for Anvil Lake. (Source, U.S.D.A. Division of Forest Service, Mount Hood National Forest). 
within the watershed are two well traveled roads. On the north end of the lake there is an area which is used by campers. This area is on a ridge approximately $91 \mathrm{~m}$ (100y) above the lake (Figure 5).

The elongate basin is located between two small ridges. It supports a substantial growth of macrophytes (unidentified) and a number of standing snags. Unidentified waterbirds and amphibians were found along the shoreline.

The water appears dark. A number of downed trees extend into the water from the shoreline, as do a number of floating logs. The bottom substrate is deep mud which yielded a sulphurous odor when the boat anchor was hauled in.

\section{CRIPPLE CREEK LAKE}

North and slightly east of Ripplebrook Ranger station approximately $22 \mathrm{~km}(13.6 \mathrm{mi})$ is cripple Creek Lake. It is found on the High Rock quadrangle (USGS) topographical map at T5S, R7E, Sec. 19 .

Cripple creek lake is not accessible by automobile. It requires a hike-in of approximately 50 minutes on USFS trail 702 (APPENDIX A). The trail is well used.

Cripple creek Lake is a relatively long, finger-shaped lake set within a heavily forested perimeter. On the north side of the lake are a number of access points. The relatively large watershed contains no clearcuts 
(a)

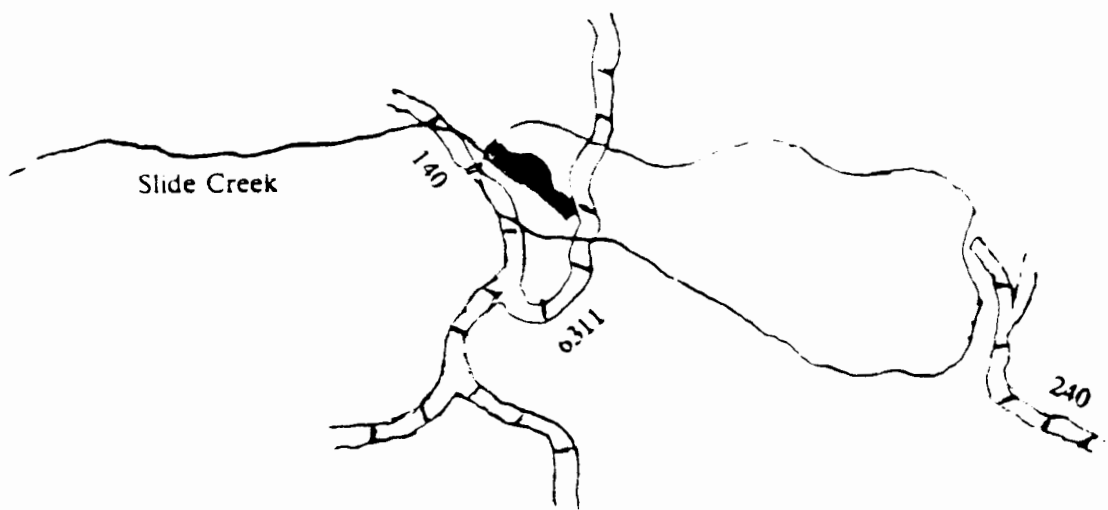

0.4 KILOMETER

(1/4 MIIE)

(b)

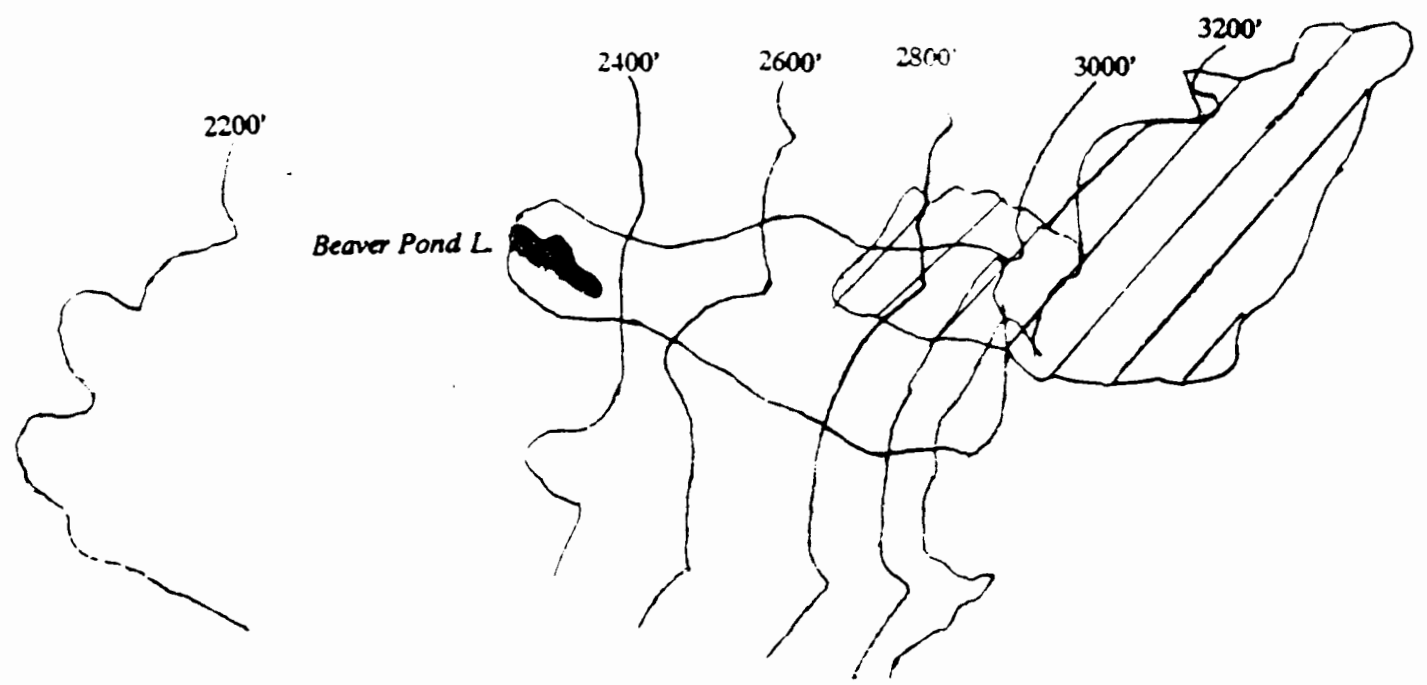

Figure 5. Road and trail system (a), and contours and clearcuts (b), for Beaver Pond Lake. clearcuts are designated by hatchlines. 
but does contain two major trails (USFS trails 702 and 517). Cache Meadow lies in the center of the watershed. On the edge of the meadow is an abandoned cabin or shed.

The contour relief of the watershed is approximately $212 \mathrm{~m}(700 \mathrm{f})$. Most of the watershed consists of rolling forested hills. Two major stream tributaries join cripple creek before it drains into the lake. The watershed is covered with animal and hiking/horseback riding trails

On the north side of the lake is a large camping site. Near the site are a number of beached rafts which have been constructed from logs and poles cut from the site.

Cripple creek Lake is finger shaped and its basin is shallow throughout. The maximum sampling depth is just over $1 \mathrm{~m}$. Under the water column is a thick silt base. The lake has a macrophyte population more like that found in eutrophic systems, although the lake is oligotrophic according to most data. Salamanders (Taricha granulosa) were found in great numbers and fish risings were observed.

This lake and watershed is used for hunting, camping, fishing, and horseback riding (Figure 6; Figure 7). The wooded area along the north side of the lake contains a complex network of human and large animal trails.

\section{FISH LAKE}

Fish Lake is located in the ollalie Butte area approximately $54 \mathrm{~km}$ (34 mi) southeast of Ripplebrook 


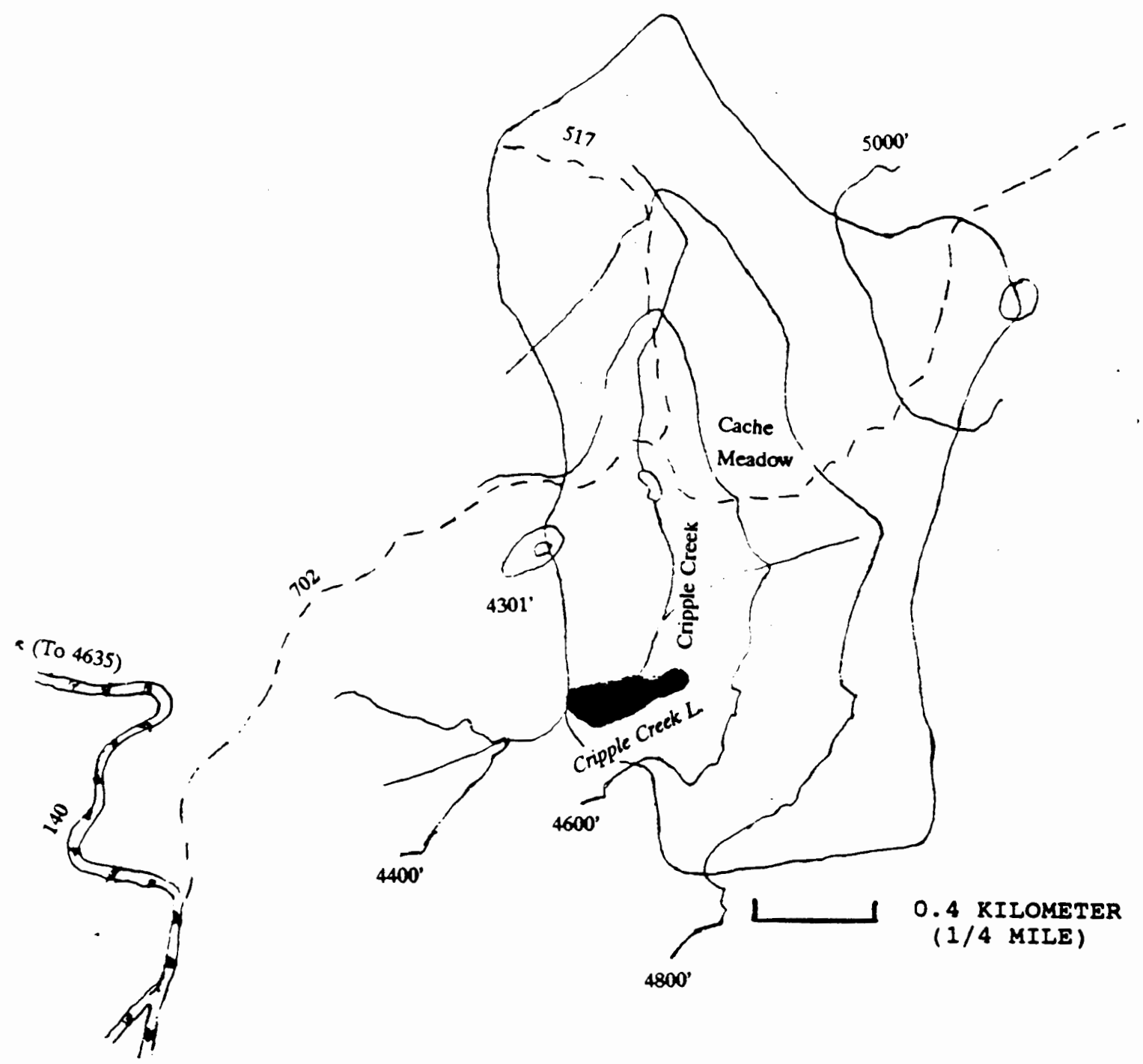

Fiqure 6. Roads, trails, and contours for the Cripple Creek Lake drainage basin. 


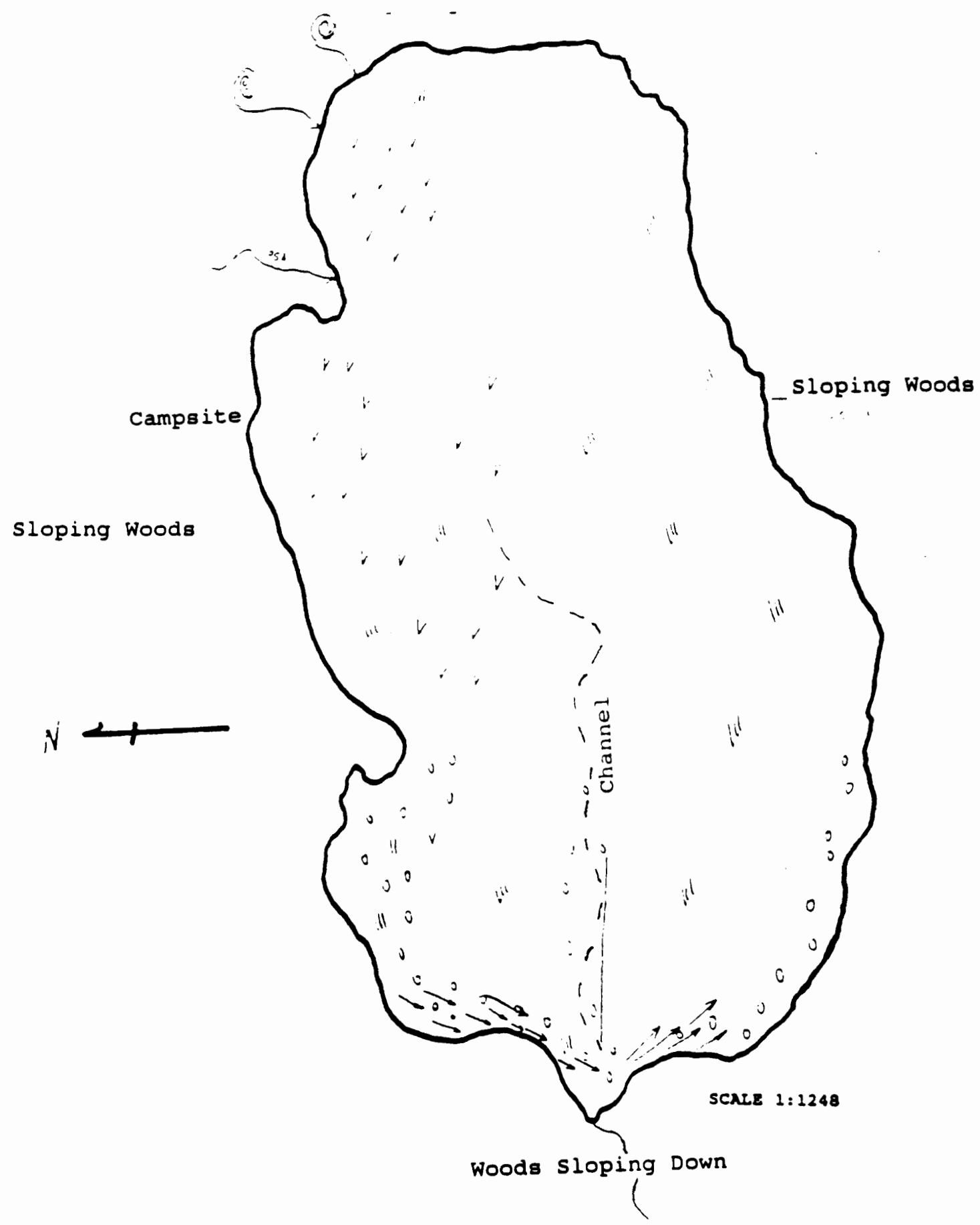

Fiqure 7. Sketch map of bathymetry and benthic substrate for Cripple creek Lake. (Source U.S.D.A. Division of Forest Service, Mount Hood National Forest). 
Ranger station. It is one of five lakes from this area which were sampled in this study. It can be found on the ollalie Butte quadrangle (USGS) topographical map at T8S, R8E, Sec. 34 .

Fish Lake is circular in shape. It has a distinctive rock-slide/clear area on the south end. The rest of the perimeter is forested.

The watershed has a contour relief of over $82 \mathrm{~m}$ (268.96 f). There are two popular hiking trails (USFS trails 706 and 717) within the drainage basin. At the northwesternmost corner of the watershed is Cornpatch Meadows.

The Fish lake basin is approximately bowl-shaped. It is the deepest lake of this study (TABLE I).

The northern portion of the basin has a silty bottom substrate. This side of the basin has a gradual contour relief. The south side of the lake has a rocky bottom and drops off sharply.

Fish lake supports macrophytes (unindentified), especially on the north and west sides. It also supports crayfish, salamanders (Taricha granulosa) and fish (unidentified).

The Fish Lake area is a very popular fishing, hiking, and camping spot. The northern campsite is located right on the immediate shoreline. There is a picnic table on the shore less than $30 \mathrm{~m}$ (approximately $33 \mathrm{y}$ ) from the waters edge. 
USFS trail 717 parallels the lake on the west side. This trail connects with USFS trail 706 which eventually connects with the popular Pacific Crest Trail. This well traveled trail system along with forest route 4691 offers generous access to Fish lake (Figure 8; APPENDIX A).

\section{GIFFORD LAKE}

Gifford Lake is located approximately $50 \mathrm{~km}(31+\mathrm{mi})$ southeast of Ripplebrook Ranger station in the ollalie Butte area. It can be located on the ollalie Butte topographical map (USGS) at T9S, R8E, Sec. 3. (Figure 2).

Gifford Lake is approximately circular except for a peninsula extending from the north shore. The Gifford Lake Trail follows a ridge which becomes the peninsula. within the watershed are two popular hiking trails-the Pacific Crest Trail on the southern part of the watershed and USFS trail 717 on the north. The watershed is bordered by Twin Peaks [elevation 1575 meters (5200 feet)] to the southwest. The basin itself is generally steep and bowlshaped although the slope on the northwest is gradual. The bottom substrate is predominantly rock.

Like Fish Lake, Gifford Lake has a rock slide area to the south. This slide is approximately 45 meters (50 yards) across. A pile of relatively large boulders extends into the basin.

Gifford Lake lacks the large macrophyte population 


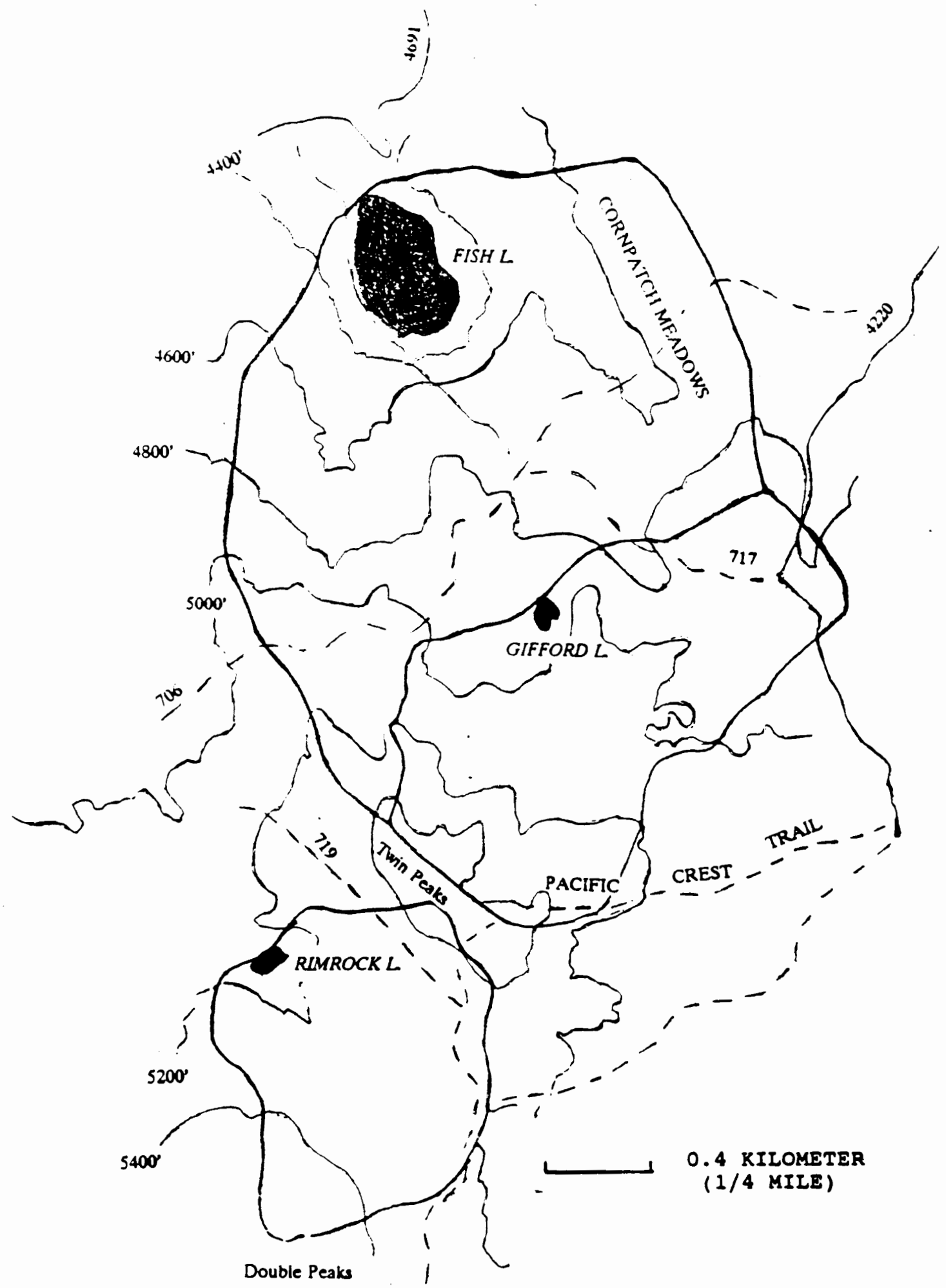

Fiqure 8. Road and trail systems, and contour relief for the Fish Lake, Gifford Lake, and Rimrock Lake drainage basins. 
found in most of the other lakes of this report. However, the fish and salamander populations characteristic of most lakes in the area are present.

Gifford Lake Trail is difficult to find since the intersection of the trail off trail 706 is not marked. Therefore, there is only moderate human impact upon the system. However this lake has two features which make it vulnerable. The first is the location of the camping site on the narrow peninsula, and the second is the easy access available on the east side (an area only sparsely forested). Refer to the bathymetric map (Figure 9).

\section{MONON LAKE}

Monon Lake is located approximately $54.4 \mathrm{~km}$ (34 mi) southeast of Ripplebrook Ranger station, and $1.2 \mathrm{~km}(0.75$ $\mathrm{mi})$ south of ollalie Lake. It is accessible by automobile on Forest Route 4220. On the ollalie Butte topographical quadrangle map it is found at T9S, R8E, Sec. 13 (Figure 2).

Monon Lake has an irregular shape, consisting of a southern basin and a much smaller and deeper northern basin. The two basins are connected by a shallow channel. The area around the perimeter is sparsely-to-heavily wooded with a trail encircling the basin.

Monon Lake is one of many lakes within the popular ollalie Lake recreational area. Within its watershed are numerous campsites, boat launches, and hiking trails. 
$\leftarrow$

Magnetic north

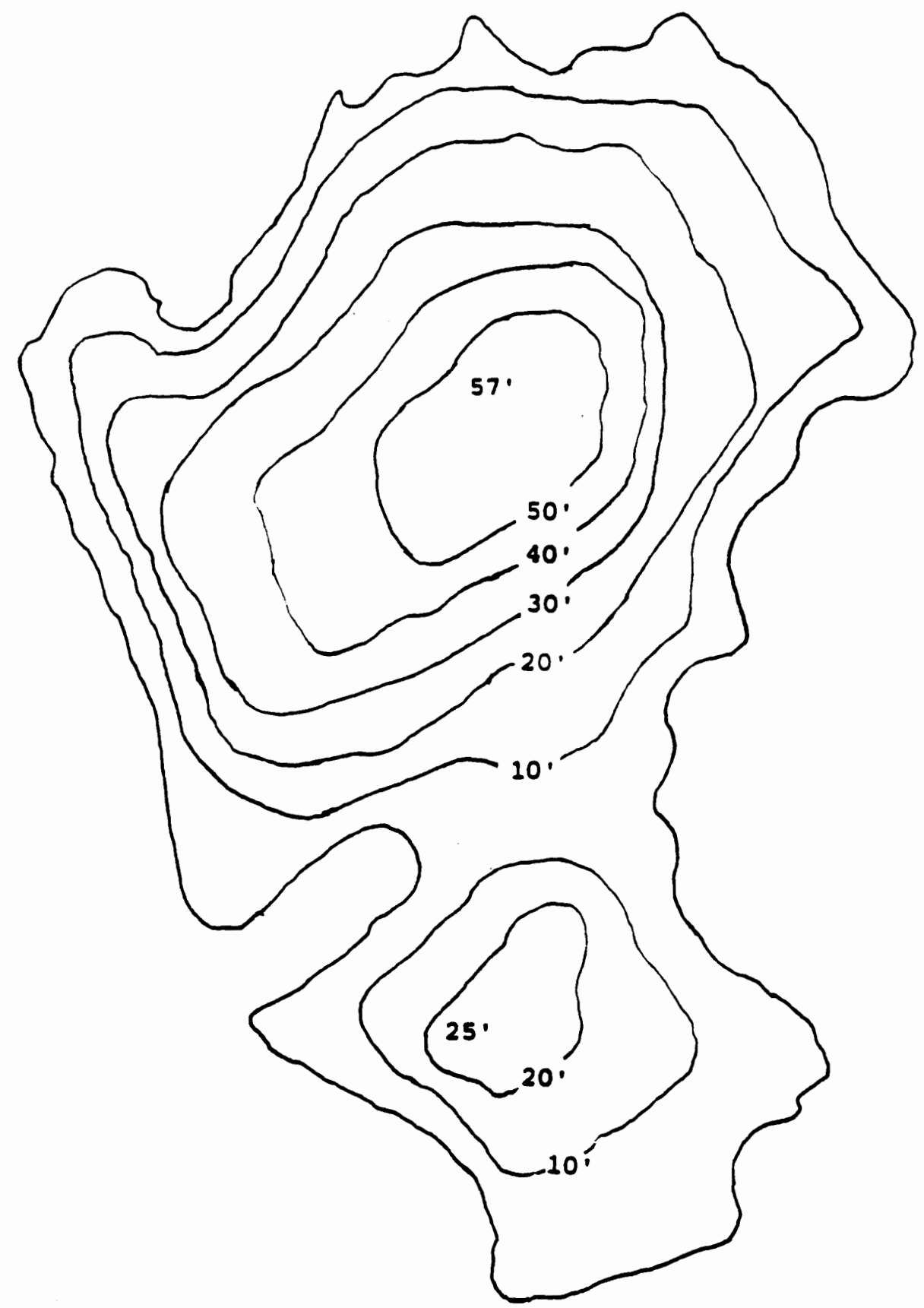

Fiqure 9. Sketch map of approximate bathymetry for Gifford Lake. 
Both of the Monon basins are heavily fished although the northern basin is probably the more popular. The numerous boat access points and camping spots are found immediately off of forest route 4220 . The trail circling Monon Lake is without significant relief and is often used by bicyclists as well as hikers.

\section{OLLALIE LAKE}

Ollalie Lake is the largest lake in the ollalie Butte area. One of over 200 lakes and ponds in the area, it is located approximately $52.8 \mathrm{~km}(33 \mathrm{mi})$ southeast of Ripplebrook Ranger station on Forest Route 4220 . It can be found on the ollalie Butte, oregon topographical quadrangle map (USGS) at T9S, R8E, Sec. 12 (Figure 2).

The contour relief of the ollalie Lake watershed is moderate. Throughout the area are stands of pine, fir, and hemlock trees.

On the west side of the lake is Forest Route 4220 . On the east side, Forest Service Spur Road 170 extends $1 / 3$ the length of the lake to the Paul Dennis Campground. USFS trail 731 begins at the end of the road and follows the northeast lake shore, circles the southeast tip, and connects with SR 180. Forest Service loop road 180 accesses the lakes southernmost camping area, the Peninsula Campground (APPENDIX A).

The ollalie basin is elongate, with a peninsula 
extending from its southeast shore. It is a very popular recreation site with 3 campgrounds and 2 boat ramps. A grocery store is located at the northern end of the lake. Cabins (which line the northeast corner of the lake), and boats can be rented at the store.

ollalie Lake itself is a very popular recreational area, and in addition the campgrounds are used by people exploring Ollalie Butte, Twin Peaks, Double Peaks, Mount Jefferson, the Pacific crest Trail, and any of the hundreds of lakes and ponds located within the ollalie Butte Scenic Area.

\section{RIMROCK LAKE}

Rimrock Lake is located approximately $56 \mathrm{~km}$ (35 mi) southeast of Ripplebrook ranger station. It can be found on the Ollalie Butte, oregon topographical quadrangle map at T9S, R8E, Sec. 10 .

The Rimrock watershed has a contour relief of over $254.5 \mathrm{~m}(840 \mathrm{f})$. The watershed is bordered by Twin Peaks to the northeast and Double Peaks to the southwest. Two trails (Pacific crest and Red Lake) cross its northeast corner. A number of lakes including Neknoberts, Cigar and Ring occupy the watershed (Figure 8).

Rimrock Lake consists of 2 basins. The main basin has a circular shape. To the southwest is a narrow channel leading into a shallow and elongate second basin. This 
secondary basin lies beneath a steep rock cliff and slide area. The bottom substrate is predominantly rock. See bathymetric map (Figure 10).

There is a rocky point extending into the lake from the east side. The basin outflow is on the westside. The inflow location was not found. The heavily wooded area around the basin showed little sign of human activity.

\section{ROUND LAKE}

Round Lake is located approximately $0.4 \mathrm{~km}(0.25 \mathrm{mi})$ off of forest route 6370 about $40 \mathrm{~km}(25 \mathrm{mi})$ south of Ripplebrook Ranger station. It can be found on the Mount Lowe topographical quadrangle map (USGS) at T8S, R7E, Sections 16 and 17 . (Figure 2).

The Round Lake watershed has a contour relief of 320.1 m (1050 f). There are 3 roads within the watershed; Forest Roads 120 and 140 and Forest Route 6355. To the south of the lake is Cache Box Meadows. Also within the watershed are clearcut areas to the north, northeast, and south. The only recreational trail within the drainage basin is the Round Lake Trail which circles the lake and connects to Forest Route 6370 .

As the name implies, the Round Lake basin is circular. The lake has two inflows, both on the east end, and one outflow thru a channel on the south side. On the east side of the lake, there is a bridge over one the inflowing 
22

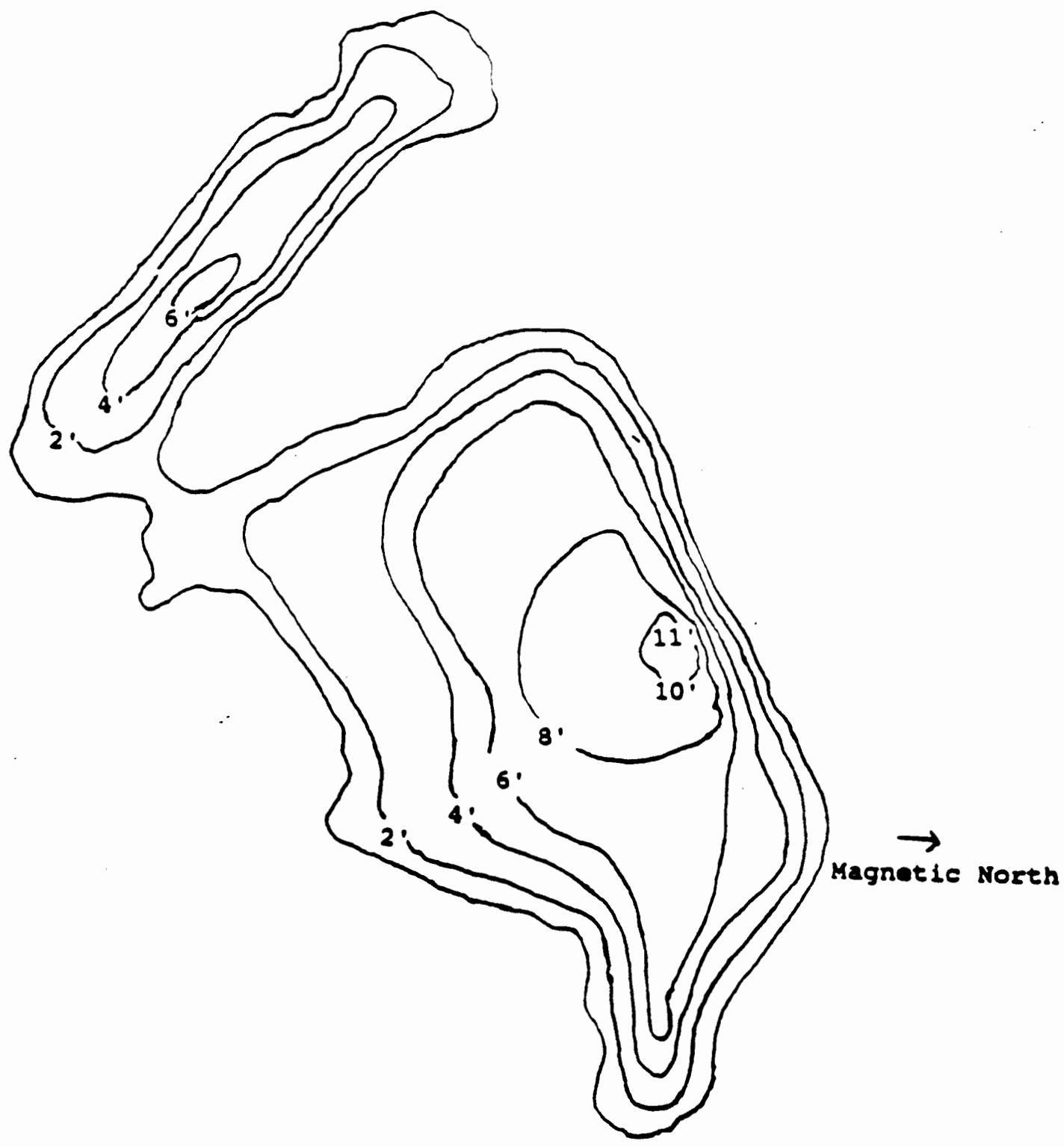

Figure 10. Sketch map of approximate bathymetry for Rimrock Lake. 
streams. The bottom substrate is silt. Macrophytic vegetation was observed along the west end.

A distinctive characteristic of Round Lake is a shoreline growth of rhododendrons (unidentified) which rim the lake. These plant assemblages are so dense that they offer an impenetrable barrier to the water's edge along most of its shoreline.

Round Lake is a popular recreational/fishing spot. Campsites are found on both sides of the lake. Fishing rafts constructed from logs cut from the nearby woods, can be found floating near the shoreline along the eastside (Figure 11).

\section{SPORTSMAN LAKE}

Sportsman Lake is located approximately $48 \mathrm{~km}$ (30 mi) south of Ripplebrook Ranger Station (Figure 2). It can be found on the Breitenbush Hot Springs topographical quadrangle map at T9S, R7E, Sec. 2 .

The Sportsman Lake watershed has contour relief of approximately $251.1 \mathrm{~m}(825 \mathrm{f})$. The watershed is bordered by Bald Butte on the south and by two large clearcuts on the northwest. There is an extensive forest road system throughout the watershed (Figure 12).

Within the watershed are two basins. Collectively these basins are called Sportsman Lakes. The basin studied for this report is the westernmost one, which is located in 


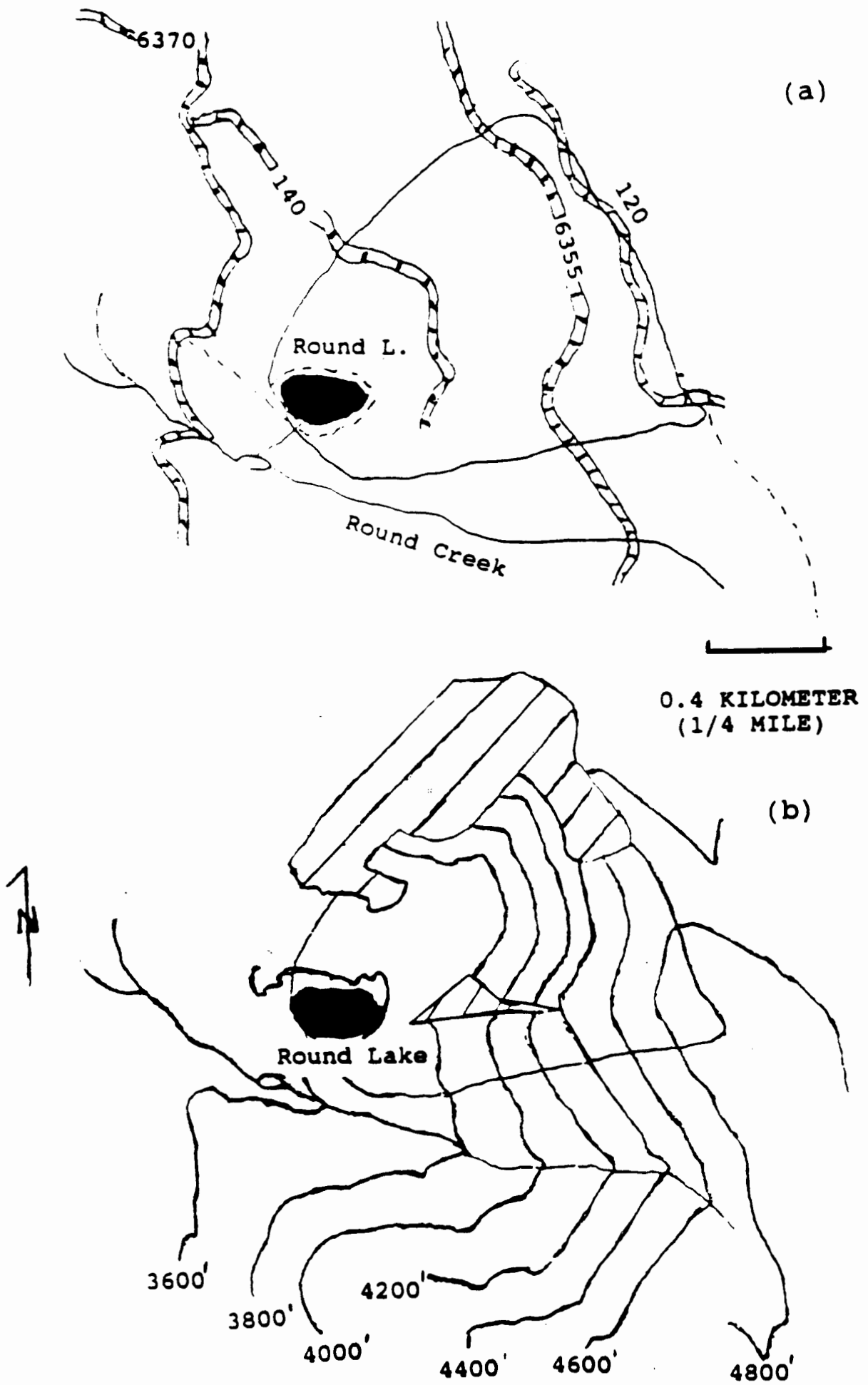

Fiqure 11. Road and trail systems (a), and contours and clearcuts (b), for the Round lake drainage basin. Clearcuts are designated by hatchlines. 

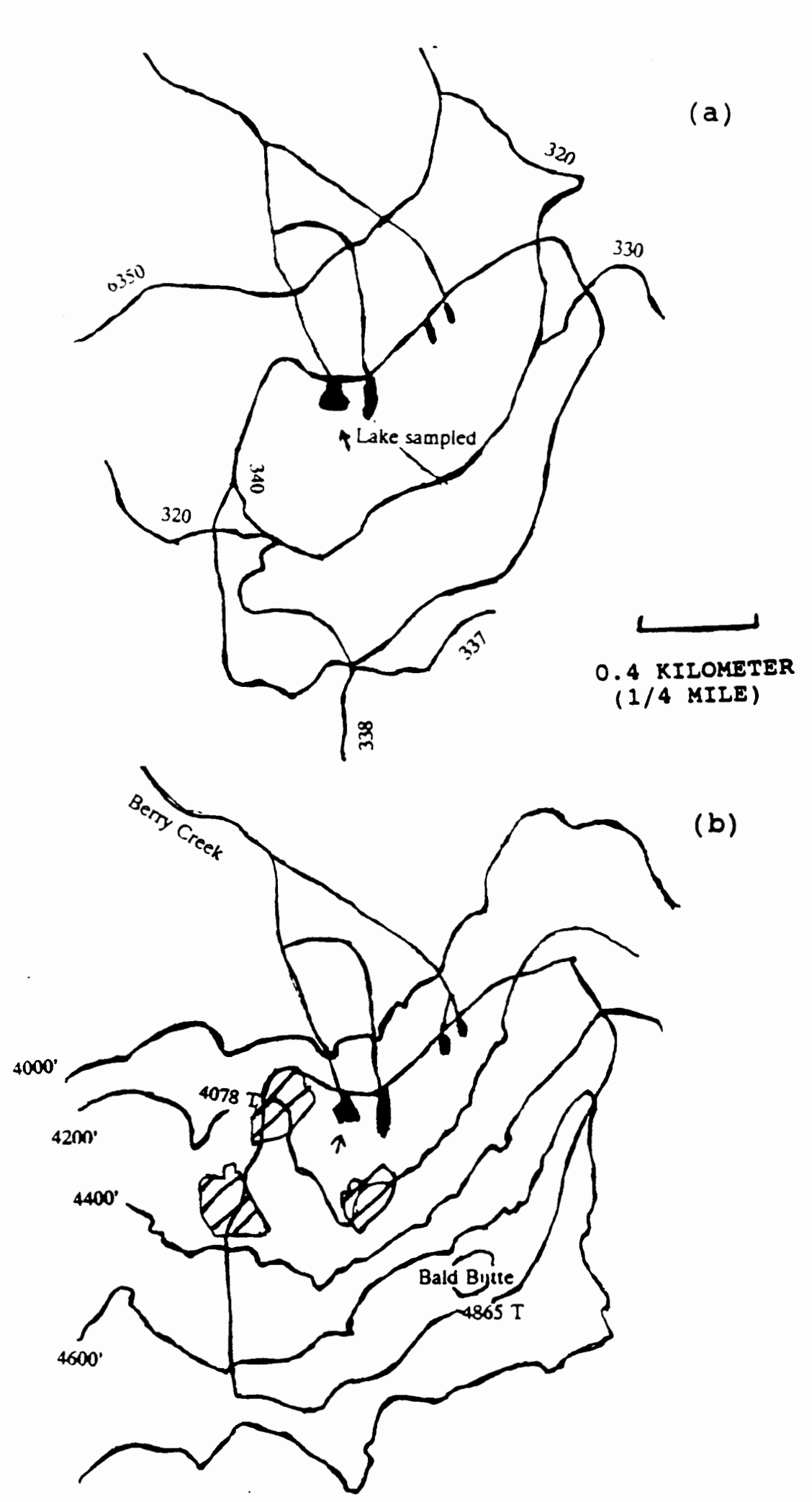

(b)

Figure 12. Road and trail systems (a), and contours and clearcuts (b), for the Sportsman Lake drainage basin. clearcuts are designated by hatchlines. 
section 2 of the U.S.G.S. topographical quadrangle map. The other basin is in section 1 . There is a ridge between the 2 basins.

The western Sportsman Lake basin is shallow throughout. The maximum recorded depth was $1.5 \mathrm{~m} \mathrm{(4.9} \mathrm{f;} \mathrm{TABLE} \mathrm{I),} \mathrm{but}$ precise depth measurements were unobtainable because of the soft-mud bottom. The deepest part of the lake is on the north side. Emergent vegetation is found throughout. The lake supports a generous population of salamanders (Taricha granulosa). On one sampling occasion there appeared to be fish rising, but no fish were actually seen. There was a beaver observed swimming around its nest-site on the southwest side of the lake.

There has been a significant amount of timber cutting activity within the sportsman Lake watershed but there was no evidence of significant recreational use. 


\section{MATERIALS AND METHODS}

\section{FIELD OBSERVATIONS}

Upon arrival at the sampling site a photograph was taken, and a general description of the lake and surrounding landscape was recorded in a field notebook. The description included general information concerning topography and vegetative patterns of the shoreline. Other initial observations recorded included the locations of trails, roads, and campsites.

After the initial description was recorded, the boats were prepared and the on-lake sample and data collection initiated. Each lake was sampled at what appeared to be its deepest point as revealed by a Humminbird ${ }^{R}$ LCR 400 depth sounder. Temperature and dissolved oxygen profiles were taken from at least five depths per lake unless the lake was shallower than $1.25 \mathrm{~m}$. Only 4 depth intervals were profiled on Anvil and Cripple Creek Lakes' since they are barely over a meter deep.

All samples were collected in linear polyethylene (LPE) bottles. The bottles were acid washed and rinsed thoroughly in distilled/deionized water, prior to sample collection. A Scott Bottle (Scott Instruments, Seattle, Wa) was used for sampling specific depths in stratified lakes. In shallow 
unstratified lakes an integrating sample bottle (homemade) was used.

\section{TEMPERATURE AND DISSOLVED OXYGEN}

Vertical profiles of temperature and dissolved oxygen were obtained using a YSI model 158 dissolved oxygen meter. First the temperature readings and then the readings for dissolved oxygen concentration were recorded at each successive depth interval. Readings were taken at a minimum of 5 depth intervals in lakes of sufficient depth. However, in most cases more than 5 depths (usually many more) were recorded. In the deeper lakes, readings were obtained at 1meter depth intervals down to within 1-meter from the bottom. In the relatively shallow lakes, intervals of $0.25 \mathrm{~m}$ were taken. The probe was intentionally kept from contacting bottom sediments since stirring up bottom particulates could affect oxygen readings.

oxygen concentration values were also determined using the winkler titration method. This technique gives more accurate values for oxygen concentration than does the YSI meter but is more time-consuming. For this reason, the Winkler method was performed on water samples taken at depths of one meter and at the approximate depth of the upper one-third of the metalimnion. 


\section{ALKLINITY AND CONDUCTIVITY}

Samples were collected from each lake in LPE bottles for measuring alkalinity. The alkalinity samples were returned to the laboratory where they were titrated with .02 $\mathrm{N} \mathrm{H}_{2} \mathrm{SO}_{4}$ to a pH of 4.0 or less. An Orion Ionanalyzer Specific Meter model 404 was used for the titrations. The alkalinity end points were determined by the Gran Plot method (Stumm and Morgan, 1981) from the range of values between $\mathrm{pH} 5$ and $\mathrm{pH} 4$.

A YSI (Yellow Springs Instrument Co.) model $33 \mathrm{SCT}$ conductivity meter was used in the field to obtain a vertical profile of conductivity. Care was taken to assure that bottom sediments were not stirred up while performing the tests.

\section{LIGHT AND SECCHI DEPTH}

When possible a light meter was taken into the field. Two different meters were used. The meters used were the Licor model LI 185-B and the Licor-1000 Data Logger. Both meters read light intensity in microEinsteins per meter squared second ( $\mu$ Einsteins $/ \mathrm{m}^{2} \mathrm{sec}$ ).

Light meter readings were taken at at least five depths except in extremely shallow lakes ( 1.5 meters or less). Extremely shallow lakes are easily 'muddied' by the stirring of bottom sediments by the light apparatus.

Water transparency was measured with a 20 centimeter 
secchi disk. The disk was lowered into the water until it disappeared, then raised through the column until it again became visible. That depth was also recorded. These two values were averaged for the final secchi depth value.

\section{MAJOR IONS}

Samples were taken for major ion analysis. Major ion analysis was performed using a Perkin-Elmer model 305-B Atomic Absorption spectrometer. Atomic absorption data were obtained for concentrations of calcium, magnesium, potassium, and sodium.

\section{NUTRIENTS}

Samples were taken from two depths for nutrient analyses, except in the extremely shallow lakes. Samples were collected at a depth of one meter and also at a depth of approximately the upper one-third of the metalimnion. The bottles were placed on ice as soon as possible.

The nutrient analyses were were performed in the laboratory. The concentrations of nitrate, ammonia, total phosphorus, soluble reactive phosphorous (SRP), and silica were determined using a Milton Roy model 401 spectrophotometer.

All laboratory nutrient analysis containers were prepared according to the following procedure. They were soap washed, tap water rinsed, rinsed six times in 
distilled/deionized water, acid soaked ( 6 hours minumum), soaked in distilled/deionized water, and again rinsed six times in distilled/deionized water.

Nitrate-nitrogen analysis was performed via the reduction of cadmium method (Jones 1984). Soluble reactive phosphorus, total phosphorus, and silica analyses were performed as outlined by Wetzel and Likens (1979).

\section{PHYTOPLANKTON}

Waters samples were collected from the one meter depth and, if the lake was stratified, from the metalimnion. Each $250 \mathrm{ml}$ bottle was treated with approximately $2.5 \mathrm{ml}$ of Lugol's solution for preservation.

Phytoplankton were indentified to at least genus and algal biomass values were obtained.

\section{ZOOPLANKTON}

One vertical tow for zooplankton was taken from each lake. The nets used were manufactured by Research Nets Incorporated (Seattle, Wa.). These nets have a mesh size of 73 microns. Two different nets were used. One had a diameter of 20 centimeters, the other a diameter of 36 centimeters.

The tows were made from just off the bottom to the surface. Approximately 150-200 ml of zooplankton sample were preserved with approximately $2.5 \mathrm{ml}$ of formalin. 
Butylated Hydroxy Toluene (BHT) was added to preserve color. zooplankton were identified to species in most cases.

\section{CHLOROPHYLL-A}

At each lake, two $250 \mathrm{ml}$ samples (one for each significant depth) were collected and filtered through a Whatman GF/F $47 \mathrm{~mm}$ glass filter. Each filter was treated with $\mathrm{MgCO}_{4}$ and put on ice as soon as possible. Also, the filters were covered with tinfoil to eliminate the possibility of chlorophyll being degraded by ambient light.

The filters were brought back to the lab where they were immediately frozen. They were then ground with a tissue grinder after which the values for chlorophyll-a were obtained using a Turner Designs model 10 fluorometer. 


\section{RESULTS}

\section{TEMPERATURE AND DISSOLVED OXYGEN}

Temperature and dissolved oxygen data were obtained twice in 1991 and once in 1992 (APPENDIX B).

In Anvil Lake the oxygen concentration was at saturation levels at all depths on all sampling dates. This is consistent with lakes that are relatively shallow and oligotrophic.

Anvil Lake is readily mixed throughout. Evidence of this is the near isothermal conditions throughout the water column. On July 8, 1991 the temperature was 19.1 degrees Celsius $\left({ }^{\circ} \mathrm{C}\right)$ at the surface and 18.4 degrees on the bottom. On August 22,1991 the surface temperature was $22.9{ }^{\circ} \mathrm{C}$ with a bottom temperature of 21.1. On July 4, 1992 the surface temperature was recorded at $18.0{ }^{\circ} \mathrm{C}$ with a bottom temperature of 17.1 degrees.

Beaver Pond Lake showed the greatest oxygen debt at depth. During the month of August 1991 the lake was well stratified with a thermocline at about $1.5 \mathrm{~m}$. By october the lake was well mixed (according to the temperature profiles) and the whole water column was nearly anoxic (less than $2 \mathrm{mg} / \mathrm{L} \mathrm{O}_{2}$ ). This is the result of bacterial respiration. It was also noted during the sampling that the 
color (extremely dark) and odor (a musky sulphur smell) of the water suggested anoxia.

On June 24,1991 the surface temperature of Beaver Pond Lake was recorded at $15.6^{\circ} \mathrm{C}$ and the bottom temperature recorded was 11.9 degrees. The surface temperature of the lake reached a high of 22.2 degrees $c$. with a bottom temperature of 13.7 on August 23,1991 . On October 25, 1991 the surface temperature was 7.8 degrees with a bottom temperature of 7.7 (Figures 13 and 14).

Cripple creek Lake is relatively shallow and has a long fetch. Lakes with such morphometric characteristics are readily mixed. Data for cripple Creek Lake showed only slight temperature variations with depth. Also, the oxygen concentration levels recorded were near saturation levels (APPENDIX B) .

The temperature of cripple creek Lake reached a high of 19.4 ${ }^{\circ} \mathrm{C}$ at the surface and a low of 16.7 on the bottom on July 7,1991. On August 21, 1991 a surface temperature of $22.0{ }^{\circ} \mathrm{C}$ was recorded with a bottom temperature of 22.4 . And finally, on July 24, 1992 the recorded surface temperature was 17.6 degrees with a bottom temperature of 16.8 .

Fish Lake is the deepest lake of the 10 studied. It is stratified during the summer with a thermocline at between 6 and 7 meters (depending upon the time of year). At that depth a significant dissolved oxygen peak was noted.

On July 1, 1991 the surface temperature recorded was 


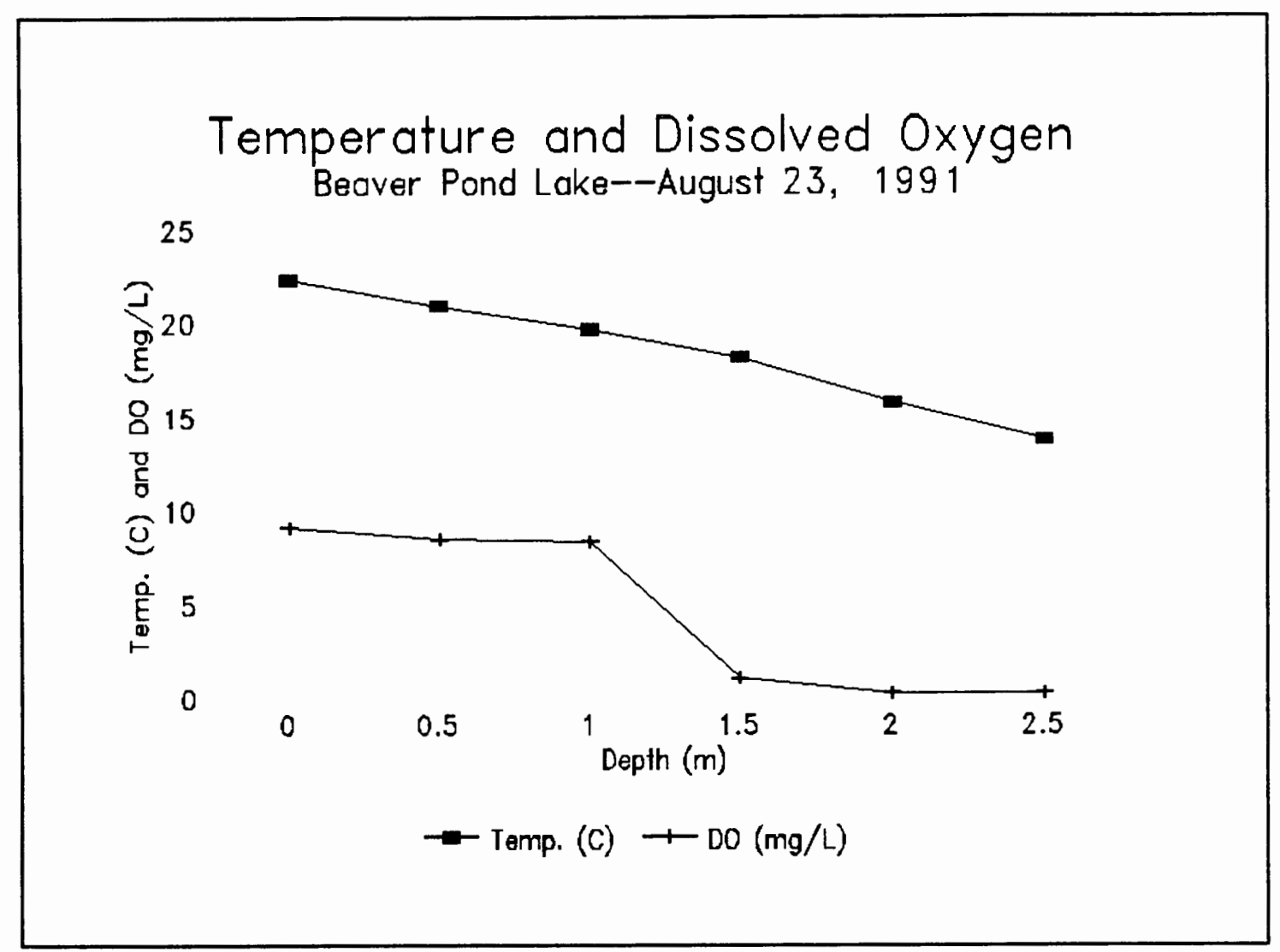

Figure 13. Temperature and dissolved oxygen profiles for Beaver Pond Lake for August 23, 1991 sampling.

$16.5{ }^{\circ} \mathrm{C}$. At the thermocline the temperature had decreased to 9.1 degrees. At the same time an orthograde dissolved oxygen profile was recorded. The temperature in the hypolimnion was 4.2 degrees. The same pattern was observed during the two successive samplings (Figure 15).

Gifford Lake is closely similar to Fish Lake in many respects. On its shoreline are distinct rock slides descending into the water. Its shape is similar to Fish Lake and it too is relatively deep, therefore it is not surprising that Gifford Lake showed a similar dissolved 


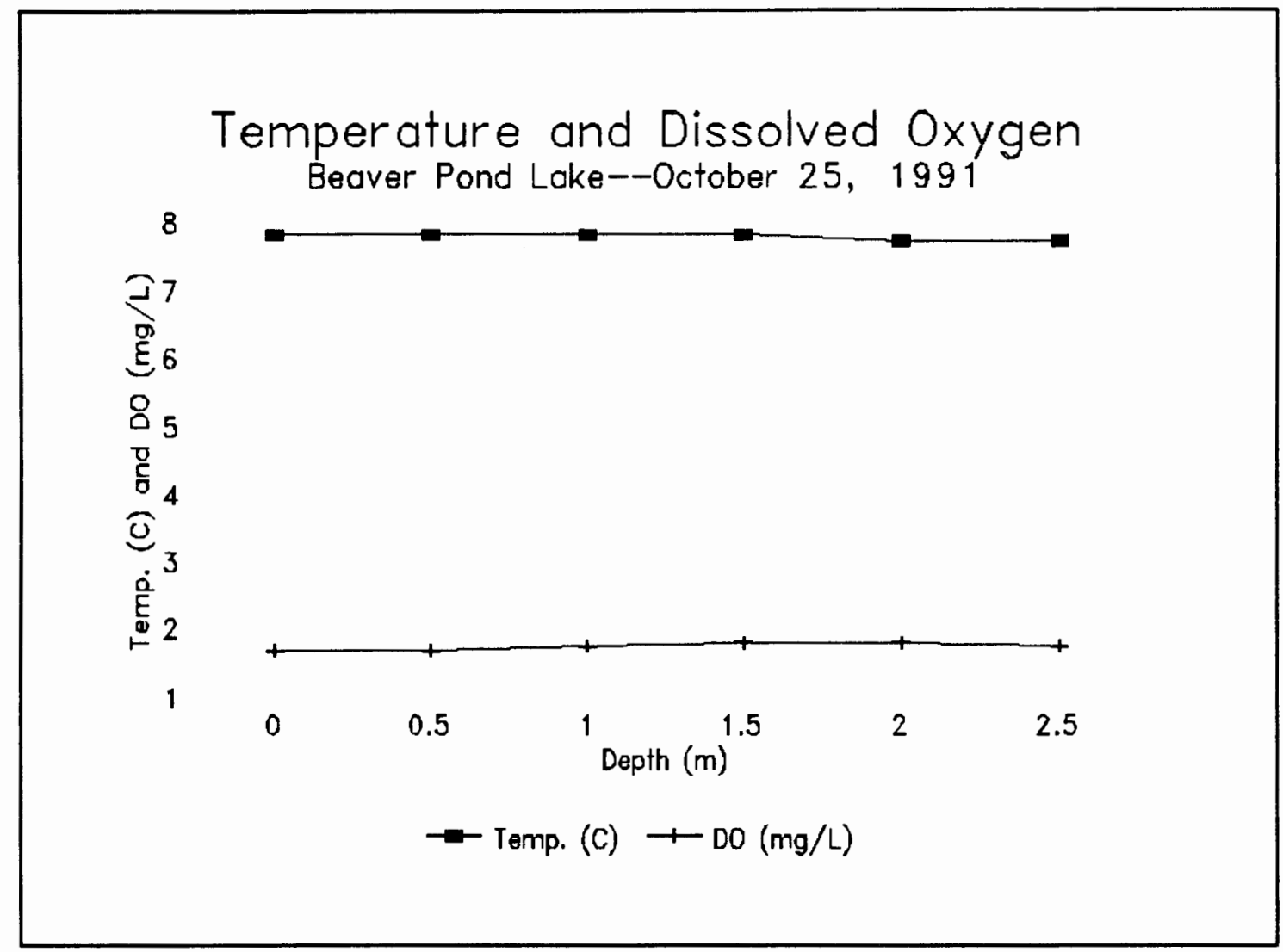

Figure 14. Temperature and dissolved oxygen profiles for Beaver Pond Lake for October 25, 1991 sampling.

oxygen profile with depth. However, stratification was not as well defined in Gifford as was the case in Fish Lake, and all depths showed oxygen concentrations at saturation.

The surface temperature of Gifford Lake was recorded at $16.4{ }^{\circ} \mathrm{C}$ on July 2,1991 with a bottom temperature of 6.6 degrees. On August 29, 1991 the recorded surface temperature was 18.1 degrees with a bottom temperature of 12.4. And finally, on July 17,1992 the surface temperature recorded was 21.4 degrees with a bottom temperature of 12.0 . Like Fish and Gifford lakes, Monon Lake is a relatively 


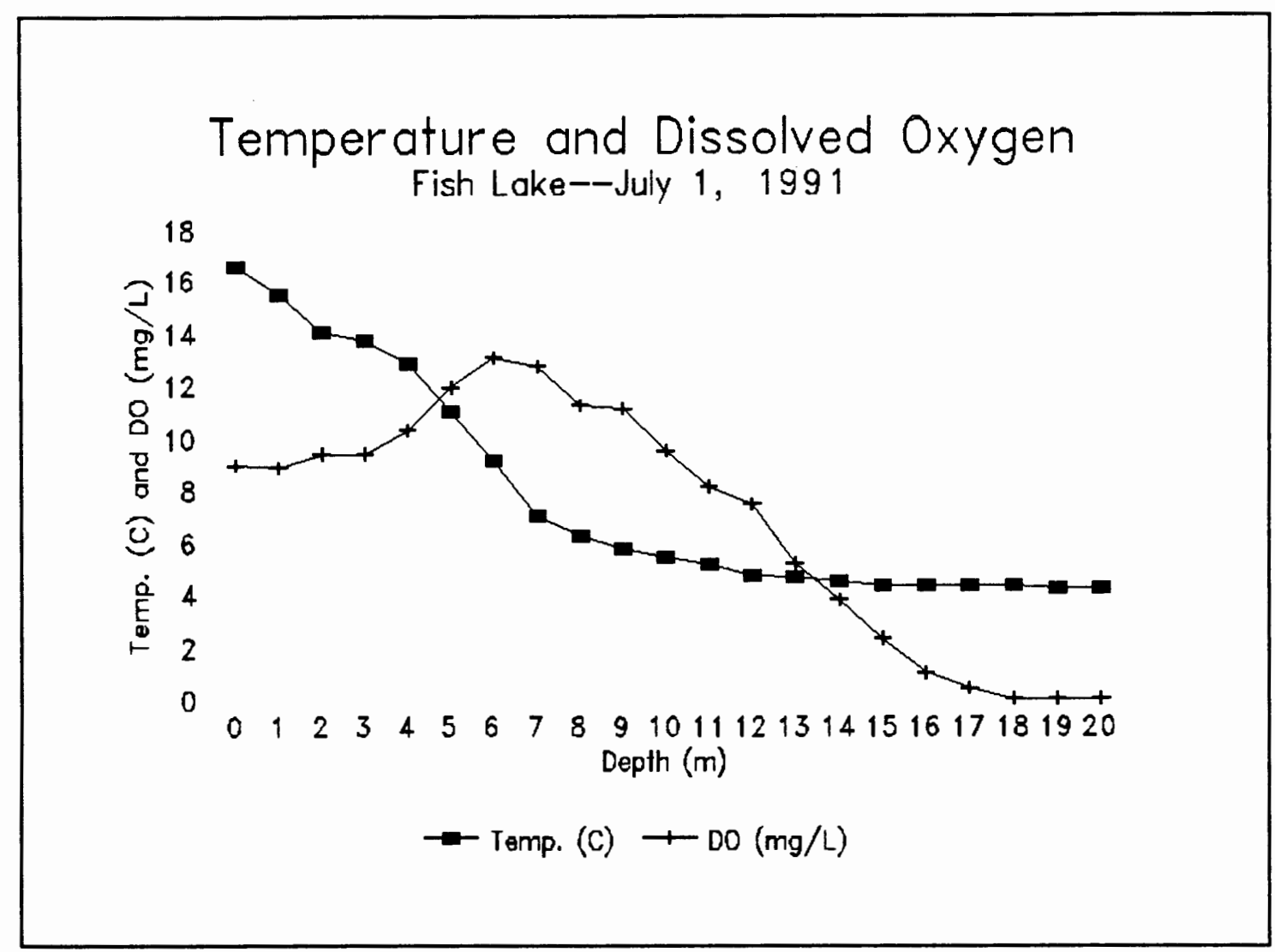

Figure 15. Temperature and dissolved oxygen profiles for Fish Lake for July 1, 1991 sampling.

large and deep system. The lake was saturated with oxygen on every sampling at every depth.

On June 29, 1991 Monon Lake had a surface temperature of $13.4{ }^{\circ} \mathrm{C}$ and a bottom temperature of 8.5 . It showed an orthograde dissolved oxygen profile to the bottom.

On September 1, 1991 and on July 11, 1992, the lake was thoroughly mixed with very little temperature variability throughout the depth of the water column (APPENDIX B).

ollalie Lake has the largest surface area of any of the of the lakes studied. Although it is relatively deep, it showed no sign of stratification during any of the sampling 
dates. The lake is located within an open basin and has a relatively long fetch. For this reason the lake is well mixed throughout the summer months.

On June 30,1991 the surface temperature reached 12.6 ${ }^{\circ} \mathrm{C}$ with a temperature of 11.3 at the 10 meter depth. On September 2, 1991 the temperature range from surface to bottom showed no significant variation from the surface reading of 17.3 degrees. On July 16,1992 the surface temperature recorded was 18.0 degrees and the bottom temperature was 17.8. On all dates (and at all depths) ollalie Lake showed saturation levels of dissolved oxygen. Round Lake is stratified throughout the summer months. On July 8, 1991 the surface temperature recorded was 20.6 ${ }^{\circ} \mathrm{C}$. The thermocline was at approximately 2 meters. The bottom temperature recorded was 9.6 degrees. On August 24, 1991 the surface temperature recorded was $20.2{ }^{\circ} \mathrm{C}$. At the 3 meter depth (the upper metalimnion) the temperature had decreased to 17.5 degrees and the bottom temperature recorded was 12.5. Finally, on July 3, 1992 the surface temperature was $19.9{ }^{\circ} \mathrm{C}$ with a temperature of 16.5 at the 3 meter depth and a bottom temperature of 9.4 .

The epilimnion of Round Lake was saturated with oxygen at all depths except at the 2-3 meter depth, where supersaturation was observed. This was probably the result of a metalimnetic algal bloom. Although the data collected on July 3, 1992 showed an inconsistant profile at 7-8 m 
depth, this datum is believed to be erroneous due to having oxygen probe in the mud (Figure 16).

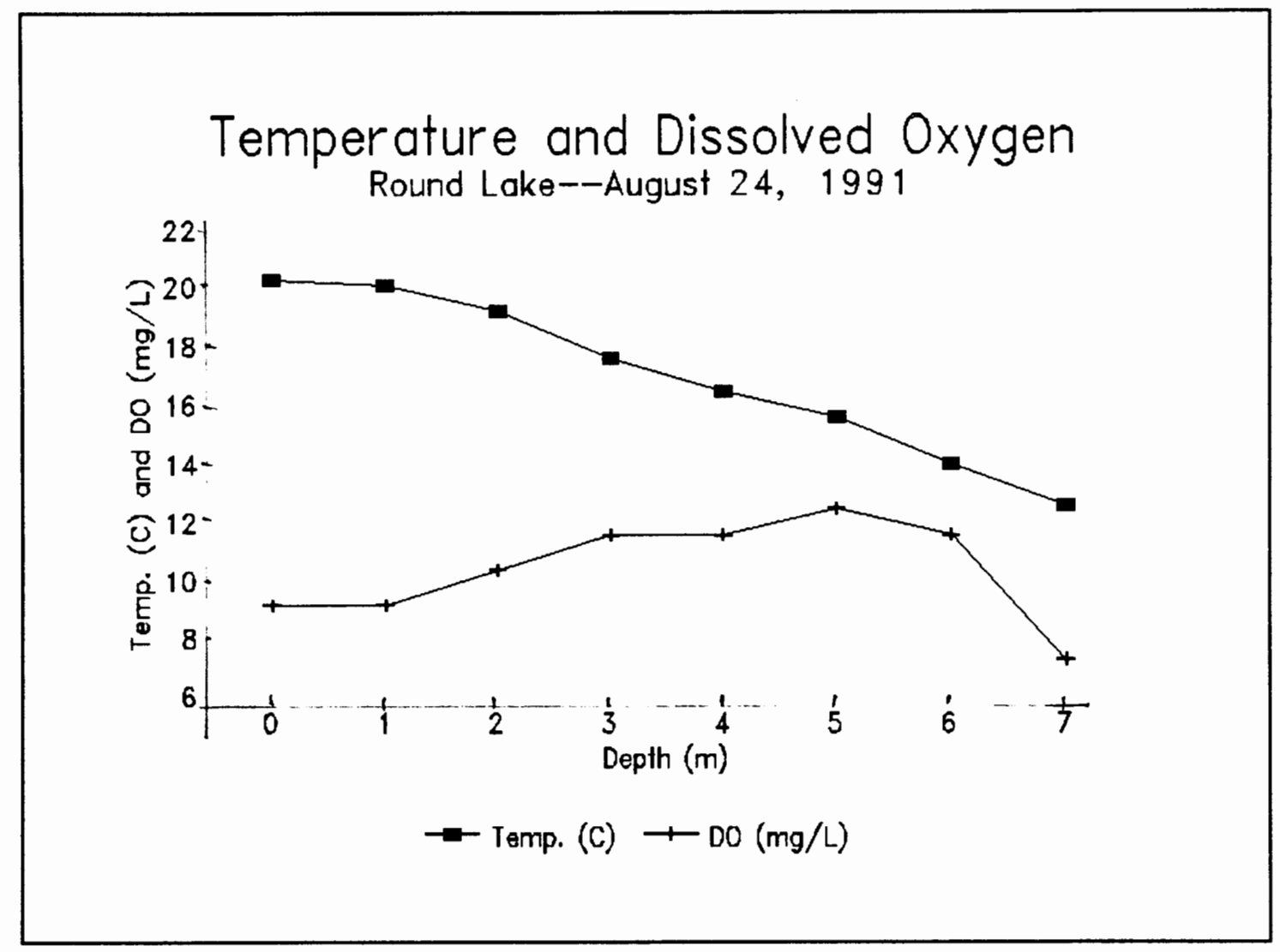

Figure 16. Temperature and dissolved oxygen profiles for Round Lake for August 24, 1991 sampling.

Rimrock Lake is relatively shallow like Anvil, Cripple Creek, and sportsman Lakes. On July 3, 1991 it had a surface temperature of $18.8^{\circ} \mathrm{C}$ and a bottom temperature of 15.7. On August 30,1991 the temperature at the surface was 15.9 degrees and the bottom temperature was recorded to be 16.0. On July 16,1992 the surface temperature was $20.5{ }^{\circ} \mathrm{C}$ with a bottom temperature of 19.5. On all sampling dates this thoroughly mixed lake was saturated throughout with 
dissolved oxygen.

Sportsman Lake showed temperature and dissolved oxygen profiles consistent with the shallower lakes of this study. This lake was well mixed throughout the summer and the oxygen concentrations were always at saturation.

On July 4, 1991 the surface temperature was recorded at $21.5^{\circ} \mathrm{C}$ and the bottom (1.25 meter depth) temperature was 18.5. On August 19, 1991 the surface temperature was 24.0 degrees with a bottom temperature of 21.6. On July 25, 1992 the surface temperature was 22.0 degrees with a bottom temperature of 18.6 (Appendix G).

\section{WATER TRANSPARENCY: LIGHT INTENSITY AND SECCHI DEPTH}

Figures 17 through 24 show the light extinction patterns through the water columns for all but Anvil and Round Lakes. These data are direct photometric measurements. A photometer was not available on the Anvil and Round lakes sampling dates. TABLE II contains the Secchi depth measurements for each lake that was deep enough to allow these tests. Also in TABLE II are two columns of light extinction coefficients. The second column contains the extinction coefficients calculated as a regression from the natural log of the light intensities versus depth. The third column presents the calculated coefficients. These extinction coefficients were calculated from the Secchi Disk measurements (TABLE II). 
LN of Light Intensity vs Depth Beaver Pond Lake--October 25, 1991

5.5

$\stackrel{7}{9}^{4.5} 4$.

德 3

ธ 2.5

z 2 -

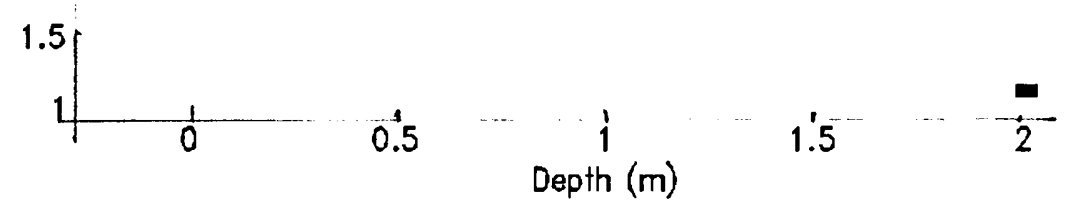

Figure 17. Light intensity versus depth for Beaver Pond Lake for October 25, 1991. 


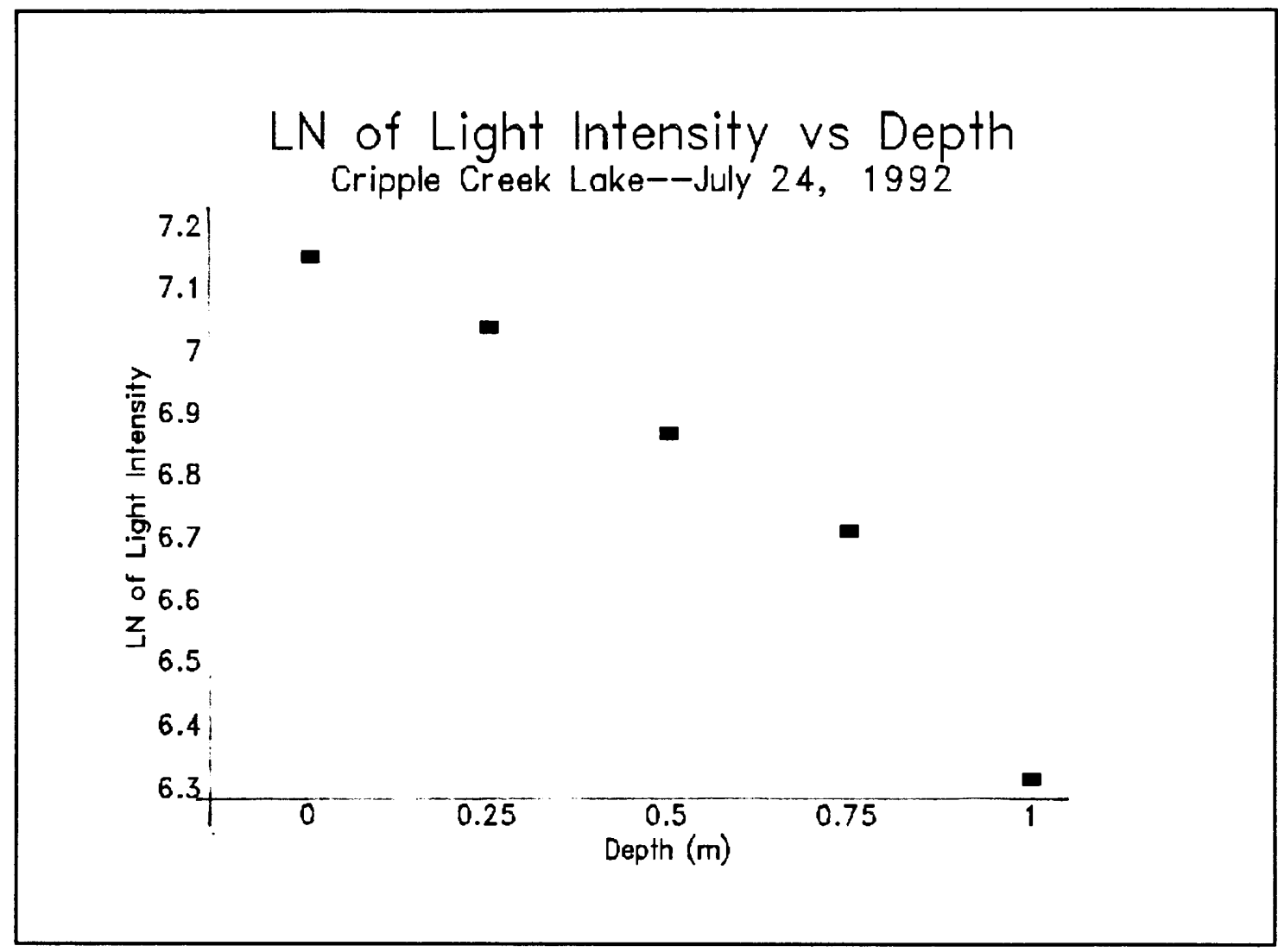

Figure 18. Light intensity versus depth for Cripple Creek Lake for July 24, 1992 sampling. 


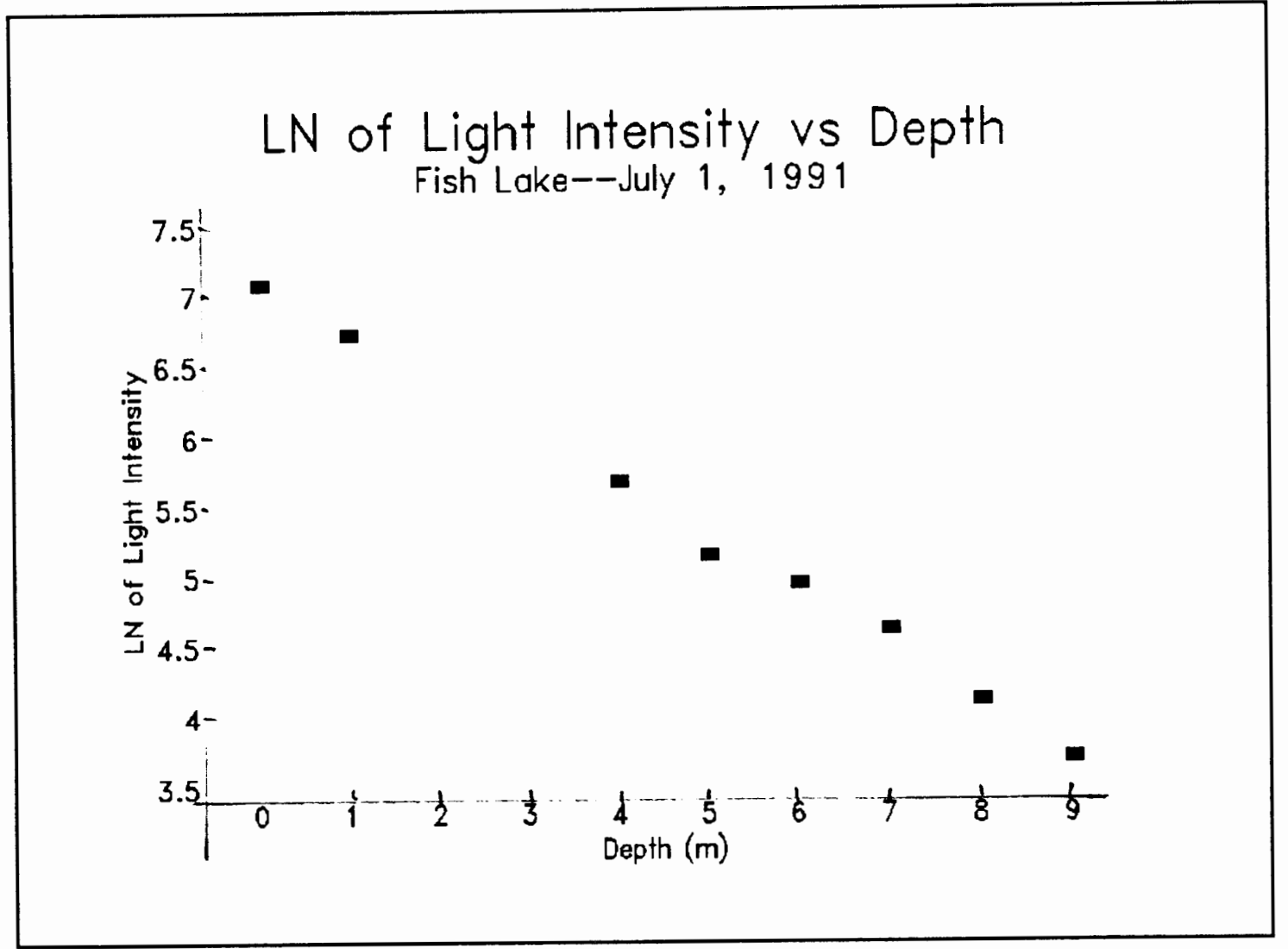

Figure 19. Light intensity versus depth for Fish Lake for July 1, 1991 sampling. 


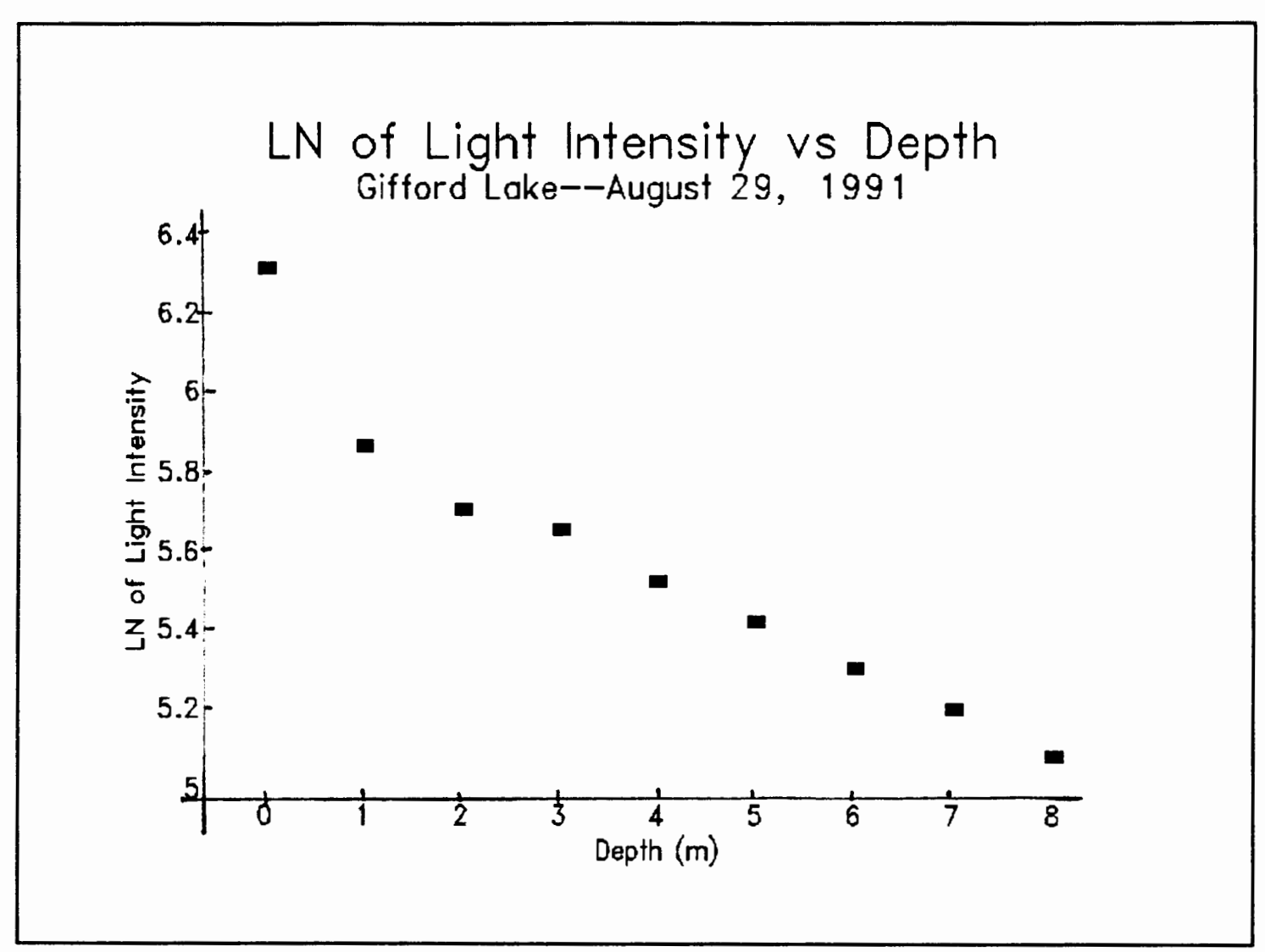

Figure 20. Light intensity versus depth for Gifford Lake for August 29, 1991 sampling. 


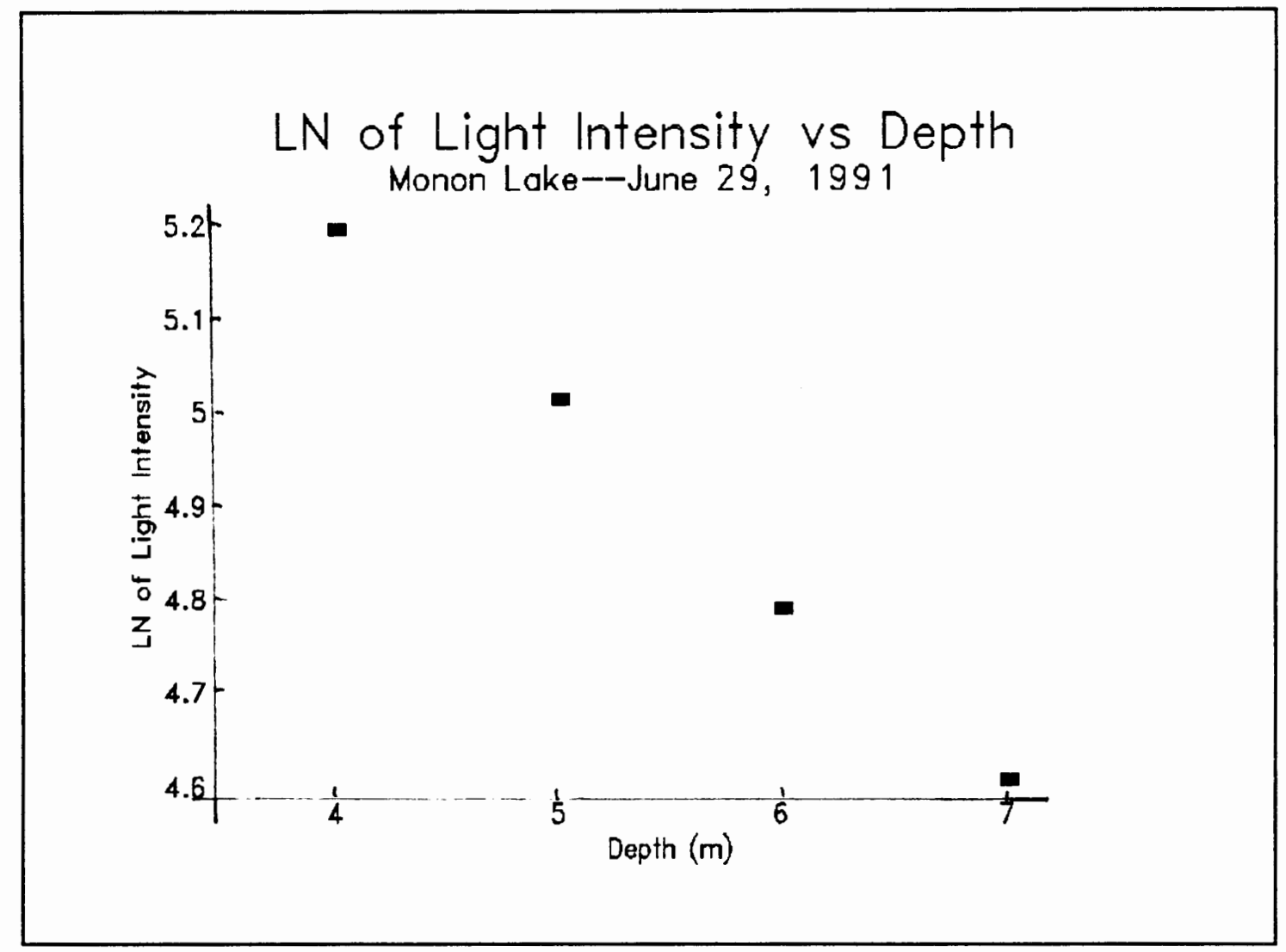

Figure 21. Light intensity versus depth for Monon Lake for June 29, 1991 sampling. 


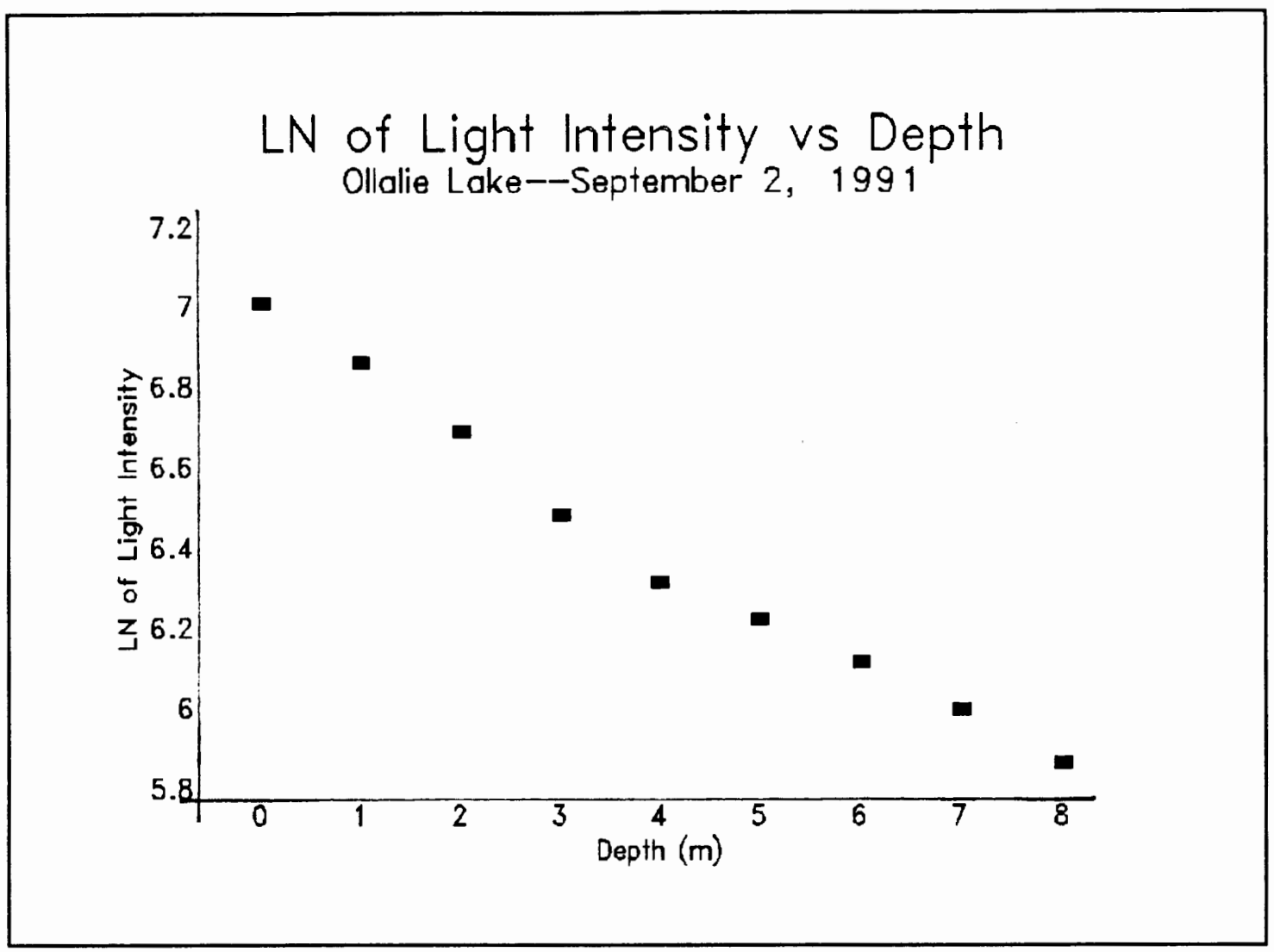

Figure 22. Light intensity versus depth for Ollalie Lake for September 2, 1991 sampling. 


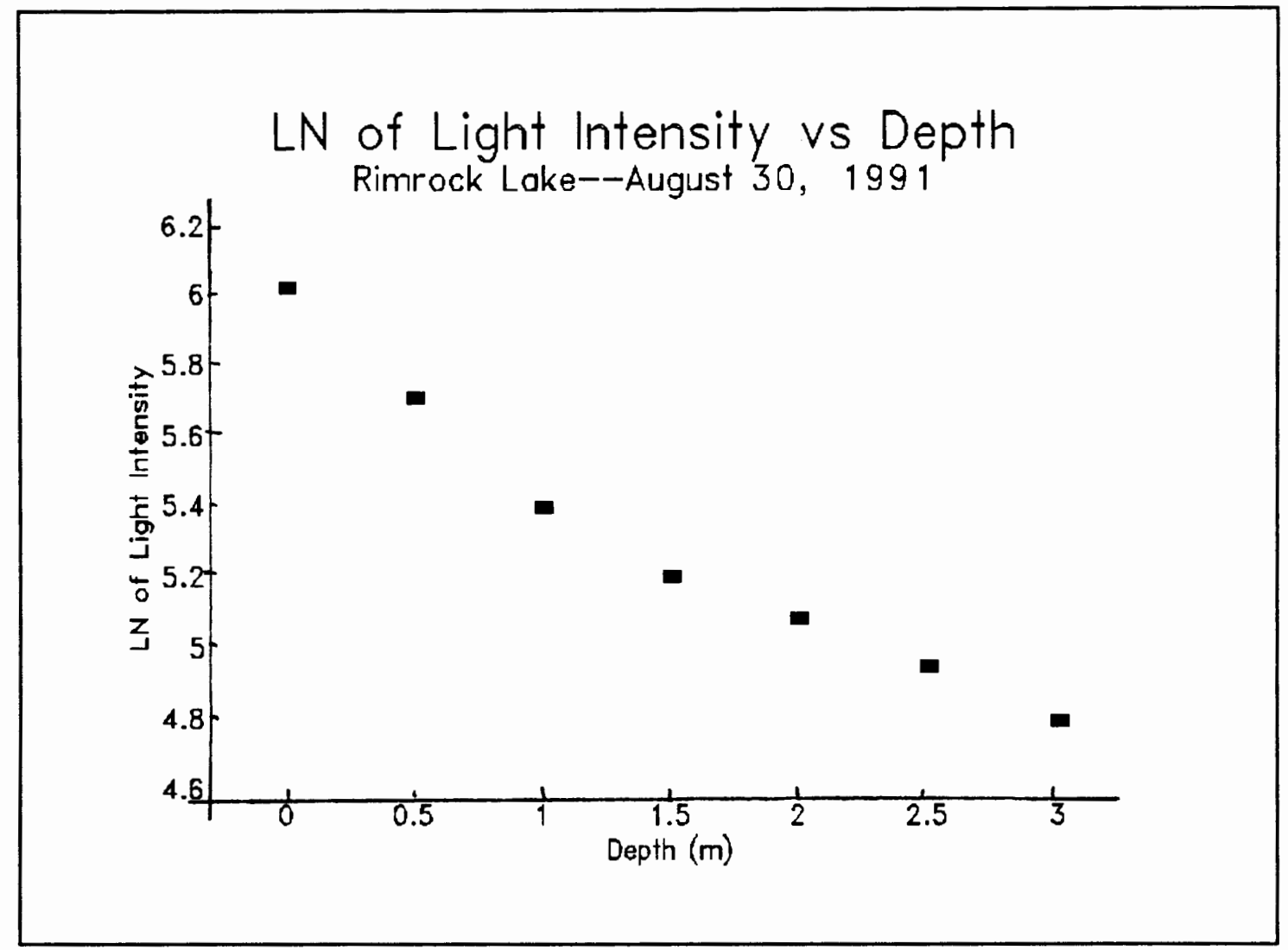

Figure 23. Light intensity versus depth for Rimrock Lake for August 30, 1991 sampling. 


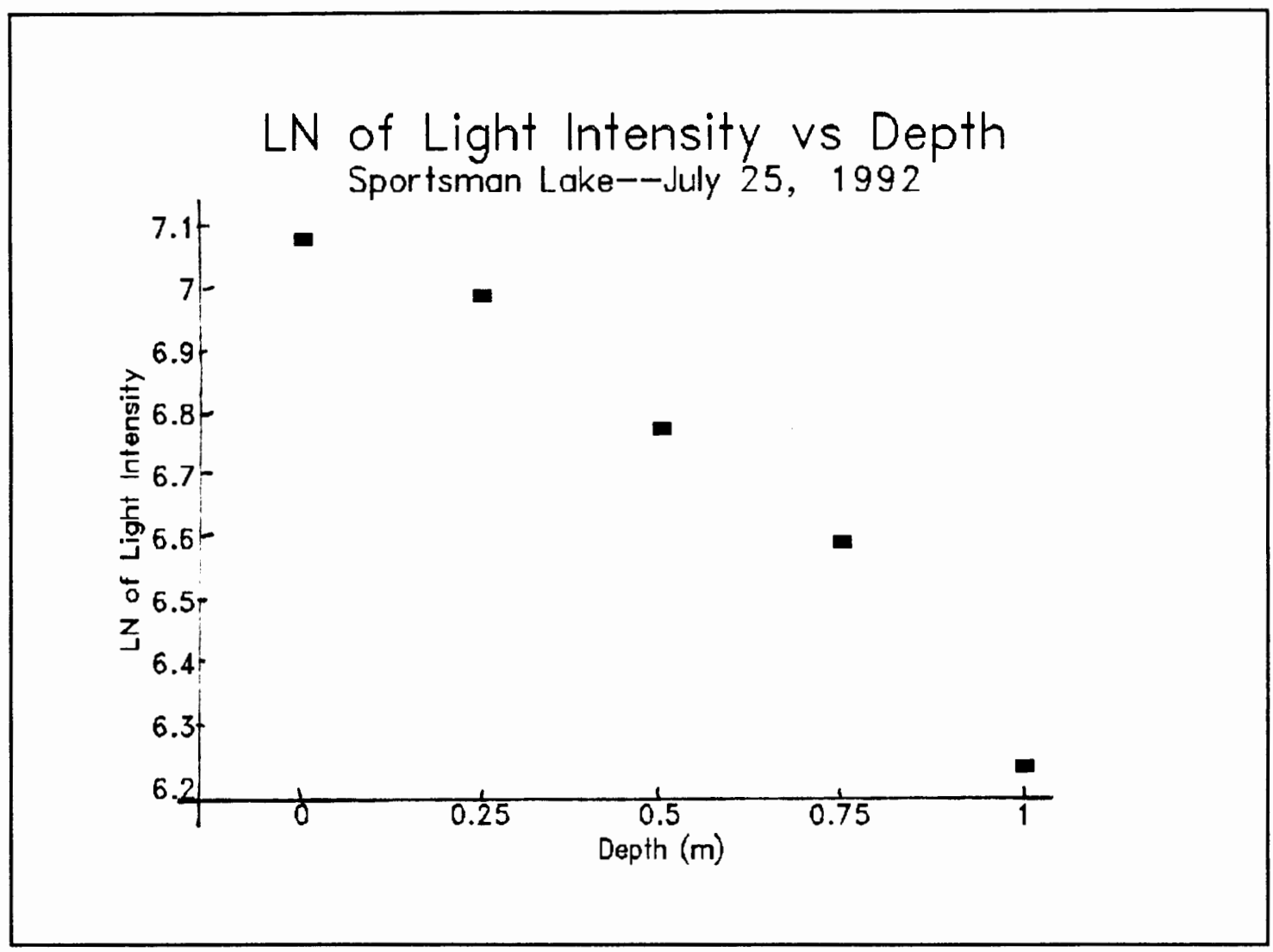

Figure 24. Light intensity versus depth for Sportsman Lake for July 25, 1992 sampling. 
It is possible to compare the extinction coefficients which were calculated from photometric data $\left(E_{p}\right)$ with the extinction coefficients estimated from the secchi depth data $\left(E_{S D}\right)$. Secchi depth is approximately $10 \%$ of the surface light intensity. The formula for determining the extinction coefficient using secchi data is $E=1.7 \mathrm{z}_{\mathrm{SD}}$ (taken from empirical data) where $z$ is the mean secchi depth (Wetzel, 1983).

TABLE II

WATER TRANSPARENCY DATA

\begin{tabular}{|c|c|c|c|}
\hline & $S D(m)$ & $E_{S D}$ & $E_{p}$ \\
\hline Anvil & s. & - & n.d. \\
\hline Beaver Pond & 1.70 & 1.00 & 1.00 \\
\hline Cripple Creek & s. & - & 0.59 \\
\hline Fish & 4.96 & 0.34 & 0.38 \\
\hline Gifford & 13.6 & 0.12 & 0.11 \\
\hline Monon & 8.6 & 0.19 & 0.20 \\
\hline Ollalie & 13.2 & 0.13 & 0.14 \\
\hline Rimrock & s. & - & 0.39 \\
\hline Round & 5.11 & 0.33 & n.d. \\
\hline Sportsman & s. & - & 0.67 \\
\hline
\end{tabular}

s. = too shallow for secchi measurements n.d. = no data

The euphotic zone is an estimation of the depth to which photosynthetic activity can be maintained as a function of light availability. It is commonly assumed that the euphotic zone extends to the depth at which light intensity has decreased to $1 \%$ of surface light intensity. The $1 \%$ light intensity can be calculated from the equation $z$ $=\ln (.01) / \mathrm{E}$, where $\mathrm{z}$ is the depth at the $1 \%$ intensity and $\mathrm{E}$ 
is the extinction coefficient. It was determined that all of the lakes except Fish Lake have sufficient light at the bottom of the water column for photosynthetic activity. In Fish Lake the light availability fell below the necessary $1 \%$ at just over 12 meters. The assumption that little photosynthesis is occurring below this depth is consistent with the dissolved oxygen data for this lake (Figure 15).

\section{NUTRIENTS}

Most chemical compounds found in fresh water systems are found in concentrations high enough to meet the demands of the phytoplankton and other aquatic flora. These compounds are the structural components of plant and algal cells and therefore limit population densities.

In freshwater lakes it is most commonly phosphorus (available only in the $\mathrm{PO}_{4}$ form) which is the limiting nutrient. Therefore any allochthonous source of phosphorus such as human or animal waste or dishwashing detergent, can significantly increase phytoplankton standing crop.

Lakes are sometimes deficient in fixed nitrogen. Often lakes which are low in nitrogen but which have sufficient phosphorus support relatively large populations of bluegreen algae. These algae can fix atmospheric nitrogen, into a form which can be assimilated by the cells.

silicon is a nutrient which is utilized by diatoms. It is a structural component of the frustule. Therefore silica 
concentration data is valuable when doing a lake study.

TABLE III contains the data for the concentrations of nitrite-nitrogen, ammonium-nitrogen, phosphate-phosphorus, total-phosphorus, and silicate.

\section{MAJOR IONS, CONDUCTIVITY, AND ALKALINITY}

There are seven major inorganic ions present in fresh water lakes (TABLE IV). Major cations are calcium, magnesium, sodium, and potassium; major anions are carbonates (primarily bicarbonate), sulfate and chloride. These ions are responsible for $99 \%$ of the salinity in natural inland waters.

The major ion data offers information concerning the lake substrate, drainage basin rock sources, wet-dry deposition, evaporation/precipitation balance (Wetzel, 1979), alkalinity, and conductivity (TABLE V) .

Conductivity measurements provide important information as to the total ionic composition of the lake. Relatively low conductivities often indicate oligotrophic conditions. The alkalinity of lake water measures the ability of the water to resist acidification. These data are of value when making long term management decisions. The alkalinity, or acid neutralizing capacity is a description of the lakes' ability to withstand a significant allochthonous influx of acidic compounds (acidic precipitation, industrial wastes, etc.). Alkalinity data obtained from mountain lakes are 
TABLE III

NUTRIENT DATA

\begin{tabular}{|c|c|c|c|c|c|}
\hline & $\begin{array}{l}\mathrm{NO}_{3}-\mathrm{N} \\
(\mathrm{ug} / \mathrm{L})\end{array}$ & $\begin{array}{l}\mathrm{NH}_{4}-\mathrm{N} \\
(\mathrm{ug} / \mathrm{L})\end{array}$ & $\begin{array}{l}\mathrm{PO}_{4}-\mathrm{P} \\
(\mathrm{ug} / \mathrm{L})\end{array}$ & $\begin{array}{l}P_{T} \\
(u / L)\end{array}$ & $\begin{array}{l}\mathrm{SiO}_{2} \\
(\mathrm{mg} / \mathrm{L})\end{array}$ \\
\hline \multicolumn{6}{|l|}{ Anvil } \\
\hline $7 / 8 / 91$ & 2.11 & 0.02 & 19.2 & $1.04 *$ & 10.6 \\
\hline $8 / 22 / 91$ & 2.15 & 0.04 & 9.75 & 13.1 & 12.9 \\
\hline $\mathrm{DEPTH}=.5 \mathrm{~m}$ & 1.63 & 0.05 & 11.2 & 19.8 & 12.9 \\
\hline $7 / 4 / 92$ & 7.85 & 0.06 & 3.14 & 4.57 & 1.20 \\
\hline \multicolumn{6}{|l|}{ Beaver Pond } \\
\hline $6 / 24 / 91$ & 12.5 & 0.27 & 8.46 & 51.6 & 14.5 \\
\hline $\mathrm{DEPTH}=2.5 \mathrm{~m}$ & 5.97 & 0.27 & 2.75 & 92.7 & 16.0 \\
\hline $8 / 23 / 91$ & 2.30 & 0.03 & 47.6 & 219.0 & 11.3 \\
\hline $\mathrm{DEPTH}=2 \mathrm{~m}$ & 5.10 & 0.06 & 71.9 & 146.0 & 14.9 \\
\hline $10 / 25 / 91$ & 7.10 & 0.07 & 114.0 & 554.0 & 15.0 \\
\hline $\mathrm{DEPTH}=2 \mathrm{~m}+$ & 6.40 & 0.11 & 114.0 & 496.0 & 14.1 \\
\hline \multicolumn{6}{|l|}{ Cripple Creek } \\
\hline $7 / 7 / 91$ & 2.10 & 0.04 & 23.2 & 36.4 & 13.9 \\
\hline $8 / 21 / 91$ & 1.70 & 0.05 & 11.2 & 18.3 & 16.1 \\
\hline REP. & 1.81 & 0.06 & 10.5 & 17.6 & 16.2 \\
\hline $7 / 24 / 92$ & 1.03 & 0.05 & 9.34 & 43.4 & 10.9 \\
\hline \multicolumn{6}{|l|}{ Fish } \\
\hline $7 / 1 / 91$ & 3.55 & 0.01 & 0.85 & 54.8 & 9.67 \\
\hline $\mathrm{DEPTH}=12 \mathrm{~m}$ & 3.95 & 0.01 & 1.49 & 72.8 & 10.7 \\
\hline $8 / 30 / 91$ & 3.95 & 0.01 & 1.49 & 72.8 & 10.7 \\
\hline $\mathrm{DEPTH}=7 \mathrm{~m}$ & 1.53 & 0.12 & 0.35 & 27.4 & 9.35 \\
\hline $7 / 7 / 92$ & 0.99 & 0.02 & 3.36 & 44.3 & 10.7 \\
\hline $\mathrm{DEPTH}=7 \mathrm{~m}$ & 1.45 & 0.13 & 3.36 & 93.0 & 9.45 \\
\hline \multicolumn{6}{|l|}{ Gifford } \\
\hline $7 / 2 / 91$ & 3.49 & 0.06 & 0.27 & 24.0 & 1.28 \\
\hline $\mathrm{DEPTH}=11 \mathrm{~m}$ & 3.19 & 0.06 & 0.20 & 12.7 & 1.04 \\
\hline $8 / 29 / 91$ & 1.61 & 1.32 & 2.59 & 30.5 & n.d. \\
\hline DEPTH=11m & 1.59 & 1.33 & 4.10 & 33.6 & n.d. \\
\hline
\end{tabular}




\section{TABLE III}

\section{NUTRIENT DATA}

(continued)

\begin{tabular}{|c|c|c|c|c|c|}
\hline \multicolumn{6}{|l|}{ Monon } \\
\hline $6 / 29 / 91$ & 2.14 & 0.01 & 0.62 & 10.4 & 2.13 \\
\hline DEPTH $=10 \mathrm{~m}+$ & 1.74 & 0.01 & 0.72 & 11.4 & 1.44 \\
\hline $9 / 1 / 91$ & 1.33 & 0.01 & b.d. & 5.70 & 2.56 \\
\hline $\mathrm{DEPTH}=8 \mathrm{~m}$ & 1.59 & 0.02 & 1.87 & 22.0 & 2.53 \\
\hline $7 / 11 / 92$ & 9.70 & 0.02 & 13.4 & 53.3 & 3.00 \\
\hline \multicolumn{6}{|l|}{ ollalie } \\
\hline $6 / 30 / 91$ & 1.85 & 0.02 & 0.57 & 24.0 & 1.34 \\
\hline $9 / 2 / 91$ & 1.45 & 0.00 & b.d. & 1.63 & 1.43 \\
\hline $\mathrm{DEPTH}=10 \mathrm{~m}$ & 1.51 & 0.01 & b.d. & 7.05 & 1.52 \\
\hline $7 / 16 / 92$ & 0.87 & 0.01 & 2.27 & 34.0 & 2.27 \\
\hline DEPTH $=10 \mathrm{~m}$ & 0.95 & 0.02 & 2.09 & 35.6 & 0.24 \\
\hline \multicolumn{6}{|l|}{ Rimrock } \\
\hline $7 / 3 / 91$ & 3.36 & 0.01 & 0.81 & 23.6 & 0.79 \\
\hline $\mathrm{DEPTH}=1.5-3 \mathrm{~m}$ & 3.85 & 0.03 & 0.81 & 26.4 & 0.71 \\
\hline $8 / 30 / 91$ & 2.04 & 1.34 & 3.35 & 25.9 & n.d. \\
\hline $\mathrm{DEPTH}=1.5-3 \mathrm{~m}$ & 1.55 & 1.37 & 4.10 & 29.7 & n.d. \\
\hline $7 / 16 / 92$ & 0.78 & 0.02 & 11.6 & 21.4 & 0.28 \\
\hline \multicolumn{6}{|l|}{ Round } \\
\hline $7 / 8 / 91$ & 2.09 & 0.02 & 32.5 & 7.16 & 22.4 \\
\hline $8 / 24 / 91$ & 2.35 & 0.05 & 15.0 & 45.8 & 21.1 \\
\hline DEPTH $=6 \mathrm{~m}$ & 1.71 & 0.02 & 30.2 & 77.4 & 20.8 \\
\hline $7 / 3 / 92$ & 7.60 & 0.02 & 3.07 & 9.32 & 2.01 \\
\hline $\mathrm{DEPTH}=5 \mathrm{~m}$ & 7.81 & 0.06 & 2.99 & 11.1 & 2.39 \\
\hline \multicolumn{6}{|l|}{ Sportsman } \\
\hline $7 / 4 / 91$ & 2.17 & 0.02 & 1.22 & 56.9 & 10.5 \\
\hline $8 / 19 / 91 \quad(.5 \mathrm{~m})$ & 1.10 & 0.07 & 75.4 & 32.4 & 6.11 \\
\hline DEPTH $=1 \mathrm{~m}+$ & 0.87 & 0.07 & 77.6 & 33.1 & 6.05 \\
\hline $7 / 25 / 92$ & 1.45 & 0.08 & 8.97 & 27.5 & 4.51 \\
\hline
\end{tabular}


TABLE IV

MAJOR IONS

\begin{tabular}{|c|c|c|c|c|c|c|c|}
\hline & $\mathrm{Ca}^{+2}$ & $\mathrm{Mg}^{+2}$ & $\mathrm{~K}^{+}$ & $\mathrm{Na}^{+}$ & $\mathrm{Cl}^{-}$ & $\mathrm{SO}_{4}$ & $\mathrm{HCO}_{3}$ \\
\hline $\begin{array}{l}\text { ANVIL } \\
\qquad \begin{array}{l}7 / 8 / 91 \\
8 / 22 / 91\end{array}\end{array}$ & $\begin{array}{l}2.73 \\
3.99\end{array}$ & $\begin{array}{l}1.32 \\
2.45\end{array}$ & $\begin{array}{l}0.15 \\
0.11\end{array}$ & $\begin{array}{l}1.37 \\
1.91\end{array}$ & $\begin{array}{l}\text { n.d. } \\
0.50\end{array}$ & $\begin{array}{l}0063 \\
0.66\end{array}$ & $\begin{array}{l}170.0 \\
327.2\end{array}$ \\
\hline $\begin{array}{l}\text { BEAVER POND } \\
6 / 24 / 91 \\
\text { REP } \\
8 / 23 / 91 \\
10 / 25 / 91\end{array}$ & $\begin{array}{l}6.88 \\
7.55 \\
9.06 \\
13.5\end{array}$ & $\begin{array}{l}2.39 \\
2.10 \\
2.25 \\
3.97\end{array}$ & $\begin{array}{l}0.44 \\
0.52 \\
0.28 \\
0.92\end{array}$ & $\begin{array}{l}4.33 \\
4.23 \\
4.36 \\
5.91\end{array}$ & $\begin{array}{l}0.85 \\
0.73 \\
0.90 \\
1.56\end{array}$ & $\begin{array}{l}0.73 \\
0.87 \\
0.53 \\
2.51\end{array}$ & $\begin{array}{l}594.4 \\
675.0\end{array}$ \\
\hline $\begin{array}{c}\text { CRIPPLE CREEK } \\
7 / 7 / 91 \\
8 / 21 / 91\end{array}$ & $\begin{array}{l}3.50 \\
3.33\end{array}$ & $\begin{array}{l}0.61 \\
0.97\end{array}$ & $\begin{array}{l}0.27 \\
0.24\end{array}$ & $\begin{array}{l}1.93 \\
2.03\end{array}$ & $\begin{array}{l}1.72 \\
0.15\end{array}$ & $\begin{array}{l}2.38 \\
0.87\end{array}$ & $\begin{array}{l}191.3 \\
237.5\end{array}$ \\
\hline $\begin{array}{l}\text { FISH } \\
\qquad \begin{array}{l}7 / 1 / 91 \\
8 / 30 / 91\end{array}\end{array}$ & $\begin{array}{l}2.60 \\
2.09\end{array}$ & $\begin{array}{l}0.45 \\
0.54\end{array}$ & $\begin{array}{l}0.48 \\
0.48\end{array}$ & $\begin{array}{l}1.38 \\
1.42\end{array}$ & $\begin{array}{l}0.02 \\
\text { b.d. }\end{array}$ & $\begin{array}{l}0.62 \\
0.62\end{array}$ & $\begin{array}{l}103.5 \\
135.2\end{array}$ \\
\hline $\begin{array}{l}\text { GIFFORD } \\
\qquad 7 / 2 / 91 \\
8 / 29 / 91\end{array}$ & $\begin{array}{l}0.37 \\
0.22\end{array}$ & $\begin{array}{l}0.07 \\
\text { b.d. }\end{array}$ & $\begin{array}{l}0.13 \\
0.12\end{array}$ & $\begin{array}{l}0.33 \\
0.33\end{array}$ & $\begin{array}{l}\text { b.d. } \\
b . d \text {. }\end{array}$ & $\begin{array}{l}5.60 \\
4.75\end{array}$ & $\begin{array}{l}1.22 \text { * } \\
\text { n.d. }\end{array}$ \\
\hline $\begin{array}{r}\text { MONON } \\
6 / 29 / 91 \\
9 / 1 / 91\end{array}$ & $\begin{array}{l}0.36 \\
0.22\end{array}$ & $\begin{array}{l}0.12 \\
0.04\end{array}$ & $\begin{array}{l}0.14 \\
0.14\end{array}$ & $\begin{array}{l}0.38 \\
0.41\end{array}$ & $\begin{array}{l}1.31 \\
\text { b.d. }\end{array}$ & $\begin{array}{l}0.46 \\
5.13\end{array}$ & $\begin{array}{l}\text { n.d. } \\
\text { n.d. }\end{array}$ \\
\hline $\begin{array}{l}\text { OLLALIE } \\
\qquad 6 / 30 / 91 \\
9 / 29 / 91\end{array}$ & $\begin{array}{l}0.29 \\
0.16\end{array}$ & $\begin{array}{l}0.07 \\
0.02\end{array}$ & $\begin{array}{l}0.12 \\
0.11\end{array}$ & $\begin{array}{l}0.33 \\
0.31\end{array}$ & $\begin{array}{l}\text { b.d. } \\
b \cdot d \text {. }\end{array}$ & $\begin{array}{l}6.09 \\
4.78\end{array}$ & $\begin{array}{l}\mathrm{n} \cdot \mathrm{d} \text {. } \\
\mathrm{n} \cdot \mathrm{d} .\end{array}$ \\
\hline
\end{tabular}




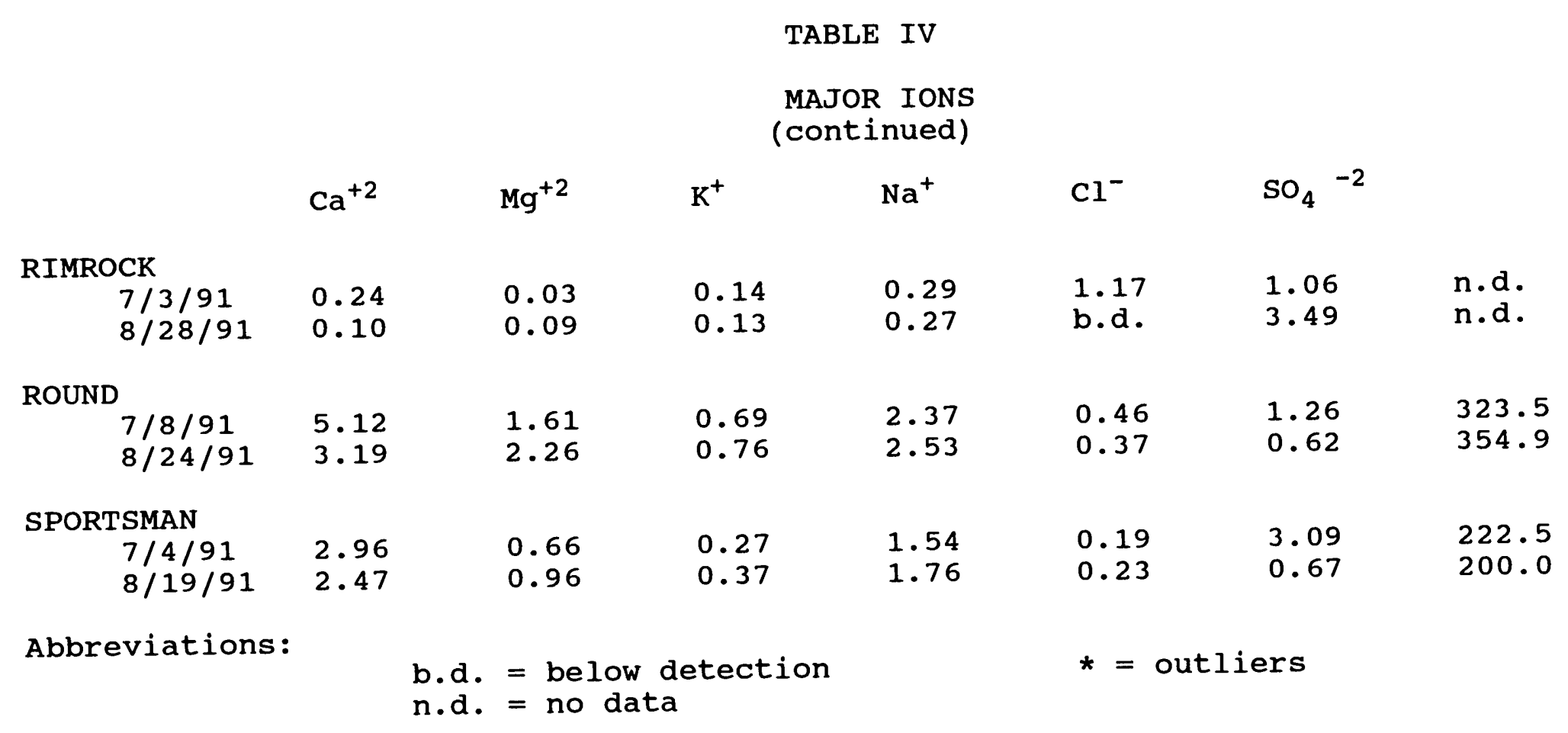

All ion data is in milligrams/liter. 


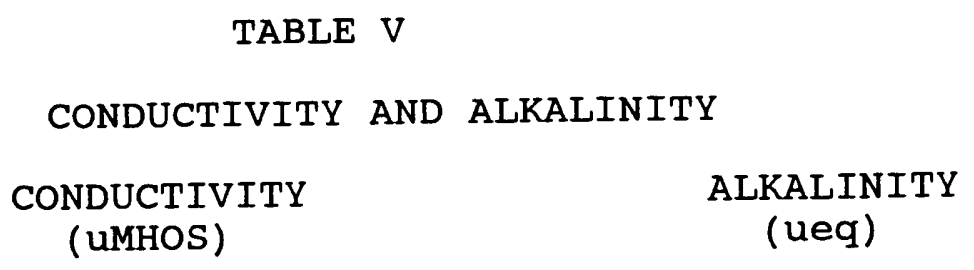

ANVIL LAKE

$7 / 8 / 91$

$8 / 22 / 91$

$7 / 4 / 92$

37

52

40

279.0

536.1

BEAVER POND

$6 / 24 / 91$

REP.

90

92

$8 / 23 / 91$

101

$10 / 25 / 91$

112

774.3

-

974.0

1106.2

CRIPPLE CREEK

$7 / 7 / 91$

$8 / 21 / 91$

40

313.5

48

389.3

$7 / 24 / 92$

FISH

$7 / 1 / 91$

$8 / 8 / 91$

$7 / 7 / 92$

31

170.0

221.6

$-$

-

11

2.00

$7 / 2 / 91$

11

$8 / 29 / 91$

$-$

MONON

$6 / 29 / 91 \quad 11$

57.7

2.34

$9 / 1 / 91$

11

$7 / 11 / 92$

-

$-$

OLLALIE

$6 / 30 / 91 \quad 10$

21.2

$9 / 2 / 91$

10

47.2

$7 / 16 / 92$

$-$ 


\section{TABLE V \\ CONDUCTIVITY AND ALKALINITY \\ (continued)}

RIMROCK

$7 / 3 / 91 \quad 10$

$8 / 30 / 91 \quad 11$

$7 / 16 / 92$

ROUND

$7 / 8 / 91$

$8 / 24 / 91$

$7 / 3 / 92$

SPORTSMAN

$7 / 4 / 91$

$8 / 19 / 91$

$7 / 25 / 92$
0

$-$

62

66

-

36

41

$-$
13.6

16.3

-

538.4

581.6

364.7

327.8 
primarily a function of the concentration of bicarbonate and carbonate. TABLE IV contains the major ion data and TABLE V the data for conductivity, and alkalinity. Refer to TABLES IV and $\mathrm{V}$.

\section{PHYTOPLANKTON}

The data for phytoplankton sample analysis are summarized in APPENDIX $C$. The analysis for species composition and identification of taxa were performed by Jim W. Sweet (Aquatic Analysts, Inc.). The species composition and population density values were used to characterize lake trophic status. Relatively high phytoplankton densities are often indicative of more nutrient-rich lakes. Also, there are algal species which are are commonly found in lakes sharing the same trophic status.

In Anvil Lake, on July 8, 1991, the predominant alga was an Ochromonas-like phytoplankter. On that date the total density of phytoplankton (individuals/ml) was 543 . On the next sampling of Anvil Lake (August 22, 1991), the dominant species was Rhodomonas minuta with 890 individuals/ml and the total phytoplankton density was 1424 individuals/ml.

In Beaver Pond Lake on June 24,1991 , the predominant alga was Rhodomonas minuta (2050 individuals/ml) and the total density of phytoplankton (all species present) was 2419 individuals /ml. On August 23, 1991 the lake had a 
dominance of the phytoplankter Cryptomonas erosa with $884 / \mathrm{ml}$ and a total density of 2147 individuals/ml.

On July 7, 1991 in Cripple Creek Lake the dominant algal species was Rhodomonas minuta $(791 / \mathrm{ml})$ and the total density of phytoplankters was 2053 individuals/ml. on August 21, 1991 the dominant alga was also Rhodomonas minuta $(341 / \mathrm{ml})$ and the total density was 531 individuals/ml.

In Fish Lake on July 1, 1991 the predominant phytoplankter was Asterionella formosa with a density of 6013 individuals/ml, and the total phytoplankton density was $7547 / \mathrm{ml}$. On August 8, 1991 the predominant species was Melosira distans $(139 / \mathrm{ml})$ and the total density was 356 individuals/ml.

In Gifford Lake on July 2, 1991 the predominant species was believed to be from the genus Glenodinium, but this was unsubstantiated. There were 21.9 individuals/ml present on this date. The total density was 31 individuals/ml. on August 8, 1991 the dominant phytoplankter was Chromulina spp. and the total density was $627 / \mathrm{ml}$.

The dominant phytoplankter in Monon Lake on June 6 , 1991 was an unidentified flagellate $(102 / \mathrm{ml})$. The total density on this date was $164 / \mathrm{ml}$ ). On september 9, 1991, the dominant species was chromulina spp. (553/ml) with a total density of $613 / \mathrm{ml}$.

Ollalie Lake on September 2, 1991 had a dominance of Chromulina spp. with 987 individuals/ml and a total 
phytoplankton density of $996 / \mathrm{ml}$. On June 30,1991 the same species was dominant with 48.5 individuals/ml and the total density was $81 / \mathrm{ml}$.

In Rimrock Lake on July 2, 1991 the dominant phytoplankter was Chromulina spp. (329/ml) and the total density was 334 individuals $/ \mathrm{ml}$. On August 8,1991 the same species was dominant $(1933 / \mathrm{ml})$ and the total phytoplankton density was 2019 individuals/milliter.

In Round Lake on July 8, 1991 the predominant phytoplankter was Asterionella formosa $(1353 / \mathrm{ml})$ and the total density was 1995 individuals/ml. On August 8, 1991 the dominant species was Quadriqula lacustris and the total density was $1443 / \mathrm{ml}$.

In Sportsman Lake on July 4, 1991 the predominant phytoplankter was chromulina spp. (273/ml) and the total density was 547 individuals/ml. On August 19, 1991 the dominant species was Ankistrodesmus falcatus $(467 / \mathrm{ml})$ and the total density was 902 individuals/ml (APPENDIX C).

\section{CHLOROPHYLL}

Concentration values for chlorophyll are used as yet another indicator of productivity. These values are closely correlated with the values for phytoplankton density and biovolume.

Since the predominant active pigment molecule of photosynthesis is chlorophyll-a, primary productivity can be 
determined from the relative concentrations of the molecule in a lake sample. The chlorophyll data are summarized in TABLE VI.

TABLE VI
CHLOROPHYLL-A CONCENTRATION
$(\mathrm{ug} / \mathrm{L})$

ANVII

$7-8-91$

8-22-91

BEAVER POND

$6 / 24 / 91$

$8 / 23 / 91$

$10 / 25 / 92$

CRIPPLE CREEK

$7 / 7 / 91$

$8 / 21 / 91$

FISH LAKE

$7 / 1 / 91$

$8 / 30 / 91$

GIFFORD

$7 / 2 / 91$

MONON

$8 / 29 / 91$

$6 / 29 / 91$

$9 / 1 / 91$

OLLALIE

$6 / 30 / 91$

$9 / 2 / 91$

RIMROCK

$7 / 3 / 91$
$8 / 30 / 91$
ROUND
$7 / 8 / 91$
$8 / 24 / 91$
SPORTSMAN
$7 / 4 / 91$
$8 / 19 / 91$
0.67

0.76

1.02

47.3

39.7

1.52

0.34

n.d.

0.76

0.16

0.26

n.d.

0.29

0.07

0.50

0.08

1.08

1.53

2.92

0.55

0.98 
ZOOPLANKTON

The data for zooplankton are summarized in APPENDIX D. The sample analysis was performed by Allan Vogel, ZP Taxonomic services. Although there is insufficient evidence to conclude that zooplankton data are reliable trophic state indicators, they are commonly used as supporting evidence when making trophic state determinations (direct communication with Allan Vogel). These data were used in that context for this report (DISCUSSION and APPENDIX D). In Anvil Lake the dominant zooplankter present on July 8, 1991 was Polyarthra dolichoptera (4043/cubic meter) and the total density of zooplankton (all species present), was 7289 individuals $/ \mathrm{m}^{3}$. On August 22, 1991 Diaptomus kenai was dominant $\left(5378 / \mathrm{m}^{3}\right)$ and the total zooplankton density was 22871 individuals/cubic meter.

On June 24, 1991 in Beaver Pond Lake, the dominant zooplankter was a Diaptomus copepodite with a density of 20290 individuals $/ \mathrm{m}^{3}$ and the total phytoplankton density was $36180 / \mathrm{m}^{3}$. On August 23,1991, a copepod nauplius was dominant $\left(2053 / \mathrm{m}^{3}\right)$ and the total phytoplankton density was 5250 individuals $/ \mathrm{m}^{3}$ ).

In Cripple Creek on July 7, 1991 the dominant zooplankter was a Diaptomus copepodite $\left(1019 / \mathrm{m}^{3}\right)$ and the total zooplankton density was 3119 individuals $/ \mathrm{m}^{3}$. on August 21, 1991 the dominant species was a copepod nauplii $\left(2343 / \mathrm{m}^{3}\right)$ and the total zooplankton density was 12249 
individuals $/ \mathrm{m}^{3}$.

In Fish Lake, the dominant zooplankter present on July 7,1991 was a cyclopoid copepodite $\left(1467 / \mathrm{m}^{3}\right)$ and the total zooplankton density was 3282 individuals $/ \mathrm{m}^{3}$. On August 8, 1991 the dominant species was also a cyclopoid copepodite $\left(12060 / \mathrm{m}^{3}\right)$ and the total zooplankton density was $18318 / \mathrm{m}^{3}$. on July 2, 1991 in Gifford Lake the dominant zooplankter was a cyclopoid copepodite $\left(1120 / \mathrm{m}^{3}\right)$ and the total zooplankton density was 2540 individuals $/ \mathrm{m}^{3}$. On August 19, 1991 the dominant species was Cyclops bicuspidatus thomasi $\left(1508 / \mathrm{m}^{3}\right)$ and the total zooplankton density was 5829 individuals $/ \mathrm{m}^{3}$.

In Monon Lake on June 29, 1991 the dominant zooplankter present was a cyclopoid copepodite $\left(1502 / \mathrm{m}^{3}\right)$ and the total zooplankton density was 2928 individuals $/ \mathrm{m}^{3}$. On september 1, 1991 the dominant species present was Daphnia galeata mendotae $\left(7349 / \mathrm{m}^{3}\right)$ and the total zooplankton density was 10984 individuals $/ \mathrm{m}^{3}$.

On June 30, 1991 in Ollalie Lake the dominant zooplankter was a cyclopoid copepodite $\left(2508 / \mathrm{m}^{3}\right)$ and the total zooplankton density was 6277 individuals $/ \mathrm{m}^{3}$. On September 2, 1991 the dominant zooplankter was Holopedium gibberum $\left(1679 / \mathrm{m}^{3}\right)$ and the total zooplankton density was 5383 individuals $/ \mathrm{m}^{3}$.

On July 3, 1991 in Rimrock Lake the dominant zooplankter was Holopedium gibberum $\left(7979 / \mathrm{m}^{3}\right)$ and the total 
zooplankton density was 9125 individuals $/ \mathrm{m}^{3}$. On August 30 , 1991 the dominant species present was conochilus spp. $\left(5967 / \mathrm{m}^{3}\right)$ and the total zooplankton density was 13800 individuals $/ \mathrm{m}^{3}$.

In Round Lake on July 8, 1991 the dominant zooplankter was Keratella quadrata $\left(244 / \mathrm{m}^{3}\right)$ and the total zooplankton density was 1427 individuals $/ \mathrm{m}^{3}$. On August 24,1991 the dominant species present was Daphnia pulex $\left(5161 / \mathrm{m}^{3}\right)$ and the total zooplankton density was 6262 individuals $/ \mathrm{m}^{3}$.

In Sportsman Lake on July 4, 1991 the dominant zooplankter present was a copepod nauplii $\left(3608 / \mathrm{m}^{3}\right)$ and the total zooplankton density was 11735 individuals $/ \mathrm{m}^{3}$. on August 19, 1991 the dominant species present was a Diaptomus copepodite $\left(8855 / \mathrm{m}^{3}\right)$ and the total zooplankton density was 28303 individuals $/ \mathrm{m}^{3}$. 


\section{DISCUSSION}

\section{PHYSICAL CHARACTERISTICS AND MORPHOLOGY}

The shape and size of a lake basin greatly influence the chemical, biological, and physical processes within the system. The shape, area, and depth of a lake taken together are powerful tools for predicting a lake's chemical and biological potential (Wetzel, 1983). Some limnologists have attempted to produce metabolic lake models using morphology as a primary consideration. Ryder (1965) used lake morphology (along with total dissolved solids) to generate his Morphoedaphic Index (MEI) which is an index used to predict nutrient status, algal biomass, and fish production. Even though recent works by Jackson (1990) and Chow-Fraser (1991) have found shortcomings with Ryder's index, lake morphology is still regarded as a primary consideration for limnological analysis (Ryder, 1974; Jackson, 1990; ChowFraser, 1991).

Gifford and Fish Lakes are relatively deep mountain lakes with depths of 18 and 20 meters respectively. Oligotrophic lakes are often comparatively deep (Wetzel 1983). In contrast, several of the lakes in this study (Anvil, Cripple Creek, and Sportsman Lakes) have maximum depths of approximately 1.5 meters, yet, they are also 
relatively oligotropic.

The area of the watershed is another factor which may influence trophic status. A lake which has a relatively high drainage basin area-to-surface area ratio is susceptible to eutrophication (Kelly 1992). A relatively large watershed can provide a source for high amounts of allochthonous organic material.

Anvil, Sportsman, and Gifford Lakes have relatively high ratios of watershed area to lake area. In the case of Anvil and sportsman Lakes, which are extremely shallow (another indication of possible eutrophic conditions), the relatively large drainage basins are important considerations. However, the relatively great depth may offset the effect of the large drainage basin.

Monon and ollalie Lakes have relatively small watershed-to-basin ratios. The low nutrient status of these lakes is consistent with predictions based on morphometric data.

The Cascade Mountains were the site of numerous volcanoes during the Cenozoic Period. During the Quaternary Period, glaciers cut deep into the mountains creating valleys and summit ice caps. Most, if not all of the lakes in this study are likely of glacial origin although Gifford and Fish Lakes could have been formed by landslide dams which blocked streams. Landslide lakes are common on lava- 
based glaciated mountains (Wetzel, 1983; Carver 1973; Scott, 1990) .

\section{TEMPERATURE}

The shallowest lakes-Anvil, Cripple Creek, and Sportsman-showed no sign of stratification on any of the three sampling dates. The temperature profiles for lakes which have extremely shallow basins are significantly affected by the ambient temperatures and wind. These lakes are readily mixed because the water density throughout the column is approximately equal.

Fish, Gifford, Monon, Beaver Pond, Rimrock, and Round Lakes showed the classic stratification patterns of dimictic mountain lakes (Petersen, 1992). Ollalie Lake was never stratified during the samplings. Ollalie Lake was probably sampled during the spring and fall turnover period, which is in the early and late summer (Johnson et. al, 1985). During these periods the temperatures from surface to bottom show little if any significant variation (Wetzel 1983).

\section{DISSOLVED OXYGEN}

The dissolved oxygen profile in a lake may be used as an indicator of primary production. Although dissolved oxygen profiles are not the most direct measure of primary productivity, the pattern of dissolved oxygen which develops in the water column over a period of stratification is an 
indication of the primary productivity taking place. A metalimnetic oxygen maximum may develop in a lake if the overlying water is sufficiently transparent. The accumulated oxygen in the metalimnion may be used as a rough estimate of primary productivity in that layer. Similarly, a hypolimnetic deficit may be used to estimate the history of primary productivity in overlying layers (personal communication, Richard Petersen). It is important to note however that dissolved oxygen concentration data taken with data for phytoplankton and light is a valuble analytical tool (Kelly, 1992; Petersen, 1992; Cole, 1979).

The Fish, Gifford, Monon, Ollalie, and Round Lakes data produced positive heterograde oxygen profiles. The metalimnetic maximum was most pronounced in Fish, Gifford, and Round Lakes. This phenomenon was also observed but to a much lesser degree in Monon Lake on the June 29, 1991 sampling. Fish, Gifford, and Round Lakes had abrupt increases of dissolved oxygen in the metalimnion which is consistent with stratified dimictic lakes. Of these three, only Fish Lake showed signs of an oxygen depleted hypolimnion. This is likely because this lake is extremely deep with a very stable thermal stratification. Also, Fish Lake has a relatively small fetch to induce mixing. Therefore, it is possible that Fish Lake is not efficiently mixed during spring and fall, allowing an oxygen deficit to accumulate over several years. 
Except for Beaver Pond Lake, the other lakes of the survey were consistently saturated with oxygen near the surface. Beaver Pond Lake is nearly anoxic throughout in the fall and was nearly anoxic in the bottom layers during the early and late summer samplings. This observation is interesting for two reasons. First, Beaver Pond Lake is relatively shallow and therefore should mix readily. Second, this lake is located in a valley which receives relatively heavy winds which might be expected to mix the water column.

During the Beaver Pond sampling probes or sampling nets retrieved from near the bottom, yielded a strong sulphurous odor. A number of anaerobic bacteria reduce sulfur as a means of meeting metabolic requirements. The accumulation of reduced sulfur is a consequence of the anoxia near the bottom.

oxygen depletion from a lake is commonly the result of bacterial decomposition of phytoplankton and aquatic macrophytes. oxygen may be depleted near the bottom by respiring organisms which consume the organic material produced by the phytoplankton and macrophytes during photosynthesis.

It is interesting to note that during the fall sampling, when oxygen depletion was most pronounced, there was only one macroscopic zooplankton species observed in the sample collected from Beaver Pond Lake. On all other occasions and at all other lakes, a diversity of fauna were 
noted. The oxygen data and zooplankton observations from Beaver Pond Lake suggest that it is unlikely that this lake can support year round populations of aerobic organisms. Therefore, this lake is not a potential recreational fishing resource.

WATER TRANSPARENCY

The rank order of the lakes from lowest light transparency (greatest extinction) to highest is as follows: Beaver Pond, Sportsman, Cripple Creek, Rimrock, Fish, Round, Monon, Ollalie, and Gifford. No light data were obtained from Anvil Lake.

As a lake becomes more productive, water transparency decreases because light is absorbed by photosynthetic organisms. Therefore light attenuation with depth may be used to indicate abundance of phytoplankton within the water column. However, light is also absorbed by suspended inorganic and dissolved organic particles (Johnson et al., 1985), so reliable conclusions cannot be drawn using only water transparency data.

Another important consideration concerning the light data for these lakes is the bottom substrate. Sportsman and Cripple creek Lakes are very shallow and have very silty bottoms. The bottom sediments were stirred up by the sampling activity (paddling of rafts, probes dragging along the bottom, etc.). Even though time was taken to allow the 
silt to settle before light measurements were performed, conditions were far from optimal and may have affected measurements of water transparency. However, if these data are reliable, these lakes are classified as mesotropic according to Carlson's Trophic Classification system (Carlson, 1977).

Beaver Pond Lake had the highest extinction coefficient of the lakes sampled. Secchi depth values indicate that Beaver Pond Lake is eutrophic. Compared with lakes surveyed for the compilation of the Western Lake Survey, Beaver Pond Lake has a very shallow Secchi Depth (Landers, 1987).

Fish, Rimrock, and Round Lakes, had similar extinction coefficients and secchi depths. These light data are consistent with those from other lakes in the cascade Mountains of the Pacific Northwest (Landers, 1987). According to Carlson's Trophic State Index, lakes with Secchi Depths of between 2 and 6 meters are mesotrophic (Carlson, 1987).

Gifford, Monon, and Ollalie Lakes had relatively low extinction coefficients and deep secchi depths when compared with lakes of the Western Lakes Survey (Landers, 1987). These lakes fit the typical oligotrophic lake light profile (TABLE I) .

During two of the three Monon Lake samplings, the Secchi Disk could be seen lying on the bottom at about 12 meters. It was only on the first sampling date (June 91) 
that secchi visibility was relatively poor. On that day a strong wind produced choppy surface water affecting visibility. Because of the water clarity on the other sampling dates, Monon Lake should probably not be considered less oligotrophic than Gifford or Ollalie Lakes.

NUTRIENTS

\section{Nitrogen}

Nitrate-nitrogen and ammonia-nitrogen are forms of fixed nitrogen that are readily assimilated by aquatic plants. The primary source of nitrate-nitrogen in mountain lakes is from the watershed.

The lakes in this study have nitrate concentrations which are consistent with other lakes studied in the Pacific Northwest (Landers, 1987). However, all of the lakes in this study except ollalie have values greater than the median value $(1.4 \mathrm{ug} / \mathrm{L})$ given for 100 lakes studied in the Western Lake Survey. The Ollalie Lake value is exactly the median value $1.4 \mathrm{ug} / \mathrm{L}$ (Landers, 1987).

\section{Phosphorus}

The values reported for total phosphorus on the 10 lakes are extremely high for oregon Cascade Lakes. It appears that systematic errors were made on many samples analyzed during the same time period using the same methodology. For that reason the values reported for soluble-reactive-phosphate (SRP) were averaged and used to 
rank order the lakes.

The SRP values for the 10 lakes were compared with the total phosphorus values that Carlson used to classify general lake productivity (Carlson, 1977). According to his system and using the SRP values, Beaver Pond Lake is eutrophic; Anvil, Cripple Creek, Round and Sportsman Lakes are meso-eutrophic; Monon and Rimrock are oligo-mesotrophic; and Fish, Gifford and ollalie are ultra-oligotrophic (Carlson, 1979).

\section{Nitrogen and Phosphorus Limitation}

The concentrations of available nitrogen, phosphorus, and carbon affect the growth of algae and other aquatic plants more than any of the other elements. In most cases, nutrient loading of nitrogen or phosphorus is implicated as the primary cause of increased eutrophication (Wetzel, 1983)

By dry weight, algae require seven times more nitrogen than phosphorus. This $7: 1$ ratio was used to determine which nutrient would be most likely to limit productivity in the 10 lakes.

The phosphorus concentrations were plotted against the nitrogen concentrations (multiplied by 7 because of the $7: 1$ ratio) to determine the limiting nutrient, and a cluster analysis was performed for each lake. The purpose of this analysis was to determine whether the data were consistent from one sampling date to the next. Clustering occurred on 
seven of the 10 lakes. The data points for Anvil, Round, and Sportsman did not cluster and therefore could not be used in the analysis.

It is likely that Gifford, Fish, Monon, Ollalie, and Rimrock are phosphorus-limited (typical for mountain lakes) while Beaver Pond and Cripple Creek appear to be limited by nitrogen and have an abundance of phosphorus. The relatively high concentration of phosphorus in Beaver Pond Lake is possibly due to its location. The lake is less than $30 \mathrm{~m}$ from of the main road and directly beneath a public access site.

Cripple Creek Lake has a number of campsites immediately on the lake. Also, the lake is encircled by trails and is a popular horseback riding area. Neither of these lakes have refuse containers or toilet facilities. Besides having relatively high values for phosphorus concentration, Beaver Pond and Cripple Creek Lakes have high values for light extinction. From these data it appears that these lakes are relatively productive and nutrient rich.

\section{Silica}

In many lakes diatoms play a major role in productivity. These organisms use large quantities of dissolved silica as a component of the cell wall (frustule). Therefore, the availability of this nutrient can significantly influence productivity in fresh water lakes 
(Wetzel, 1979; Cole, 1983).

Half of the lakes of this study have dissolved silica values which are higher than the fourth quintile (80th percentile) of lakes represented in the Western Lake Survey.

Only 3 of the 10 lakes fell within the first to fourth quintile of the survey. These lakes are Monon, ollalie, and Rimrock. Gifford Lake had a silica conconcentration value consistant with lakes within the 1st quintile (20 percentile) of the Western Lake Survey (Landers, 1987).

CONDUCTIVITY

\section{Salinity}

The specific conductivity of water is related to the concentration of the major ions present within a given volume of water (Cole, 1983).

Water conductivity values are closely correlated with values given for the concentrations of dissolved ions. Because testing for individual ions is rigorous and expensive, specific conductance profiles are often used as a substitute (Cole, 1983).

The conductivity values for the 10 lakes were compared to the values reported for the 100 lakes studied for the compilation of the Western Lake Survey.

Beaver Pond and Round Lakes have specific conductivities which are much higher than the fourth quintile (80th percentile) of lakes in the Western Lake Survey 
report. Anvil, Cripple Creek and Sportsman Lakes have conductivities which are also relatively high, falling above the 80 th percentile. The 10 lakes in this study more closely fit the profiles for lakes located in the northern Rocky Mountains (Landers, 1987).

The conductivity values representing Gifford, Monon, ollalie, and Rimrock are relatively low for lakes in this study area but well within the expected limits for lakes located in the Pacific Northwest (Landers, 1987).

\section{Cations}

Most lakes which have been formed from igneous rock have a cation ratio as follows: calcium > sodium > magnesium > potassium (Wetzel, 1983). The primary source of calcium carbonate is from igneous rocks. Although $\mathrm{CaCO}_{3}$ is abundant, only a small amount can be dissolved in pure water (Cole, 1983).

In six of the 10 lakes studied, calcium is the predominant cation. In the other 4 , sodium is dominant.

Sodium is also an abundant weathering product of igneous rock (Hutchinson, 1957). Therefore it is not surprising that it is found in relatively high concentrations in these lakes which are of volcanic-glacial origin.

Because the total cation concentrations were low in the lakes dominated by $\mathrm{Na}$, it is probably the lack of carbonates in the drainage basin which explains the low calcium/sodium 
ratio.

Calcium concentrations sometimes vary as a function of biotic uptake. Calcium is an essential element of algae and other aquatic plants. Sodium, potassium, and magnesium are more conservative ions because they are commmonly present in considerable excess of biologic demand (Wetzel, 1983).

\section{Anions}

The anionic ratio for most lakes located in the western United states is as follows: $\mathrm{HCO}_{3}>\mathrm{SO}_{4} \sim \mathrm{Cl}^{-}$. However in lakes of the Pacific Northwest, $\mathrm{HCO}_{3}$ is dominant, $\mathrm{Cl}^{-}$is next and $\mathrm{SO}_{4}$ is least (Landers, 1987). The lakes in this study are not consistent with this pattern. Sulfate is the predominant anion in Anvil, Beaver Pond, Cripple Creek, Fish, Round, and Sportsman Lakes. Relatively high values for sulfate were recorded for the other four lakes.

There are two possible explanations for the dominance of sulfur in these lakes. First, sulfur is a weathering product of pyrite, a source of sulfide in lakes. This is just one of many weathering products of volcanic rock (direct communication with Vic Menting). Second, the concentrations of the other anions are extremely low.

\section{Carbonates and Bicarbonates}

Inorganic carbon behaves dynamically in water. Bicarbonate enters the lake as the product of rock weathering processes. Carbonic acid percolation through soils and 
over rocks causes dissolution of calcium carbonate (Wetzel, 1983).

Relative concentrations of carbonate species change with pH. Bicarbonate concentration does not vary significantly in hard water-eutrophic lakes (which contain high concentrations of carbonates) but mountain lakes have relatively low concentrations of inorganic carbon. Therefore, seasonal extremes in photosynthetic activity (or allochthonous sources of $\mathrm{CO}_{2}$ ) can have a dramatic effect on the availability of bicarbonate.

\section{ALKALINITY}

The values for alkalinity (acid neutralizing capacity, ANC) were compared with values reported in the literature (Western Lake Survey). The lakes were rank-ordered from greatest acid neutralizing capacity to least as follows: Beaver Pond, Round, Anvil, Sportsman/Cripple Creek (shared the same value), Fish, ollalie, Monon, Rimrock, and Gifford.

In the Western Lake Survey, values were reported for both wilderness and non-wilderness mountain lakes. When compared to the literature values, Gifford, Ollalie, Monon, and Rimrock Lakes more closely fit the profiles for wilderness lakes (Landers, 1987).

The ANC values for Beaver Pond and Round Lakes are more consistent with non-wilderness lakes in the Southern Rocky Mountains than with lakes located in the Pacific Northwest 
(Landers, 1987).

Because the total concentration of autochthonous inorganic carbon do not fluctuate significantly within the lake, the concentration of natural water buffers is relatively static. As is usually the case in mountain lakes, these buffering anions are in very low concentration. Therefore, any allochthonous source of strong acid such as sulphuric or nitric acid from industrial sources would be expected to drastically lower pH (Baker, 1991). However, due to the location of these lakes, it is unlikely that the chemistry of these waters will be altered by acid compounds entering from the atmosphere (acid rain).

\section{PHYTOPLANKTON}

Jim Sweet has developed a trophic state index, based on phytoplankton biovolume comparable to Carlson's Trophic state Index, based on total phosphorus, chlorophyll, and light extinction (Sweet, 1986; Carlson, 1977).

The 10 lakes were rank-ordered according to algal biovolume values (highest to lowest) as follows: Fish, Beaver Pond, Cripple Creek and Anvil (shared the same value), Sportsman, Round, ollalie and Rimrock (shared the same value), Monon, and Gifford. According to these values, Fish and Beaver Pond Lakes are mesotrophic while the others are oligotrophic.

A comparison was made between the index generated 
according to sweet's biovolume index and the index developed by Carlson (based upon phosphorus, chlorophyll, and Secchi depth). Sweet's index agreed well with Carlson's indices (Carlson, 1977; Sweet, 1986; APPENDIX C).

It is interesting to note that Fish Lake has the highest trophic status of the 10 lakes according to phytoplankton data. It is doubtful that this lake is as productive as these data suggest, since other data indicate that Fish Lake is a more oligotrophic system. This discrepancy is apparently a consequence of a high metalimnetic population of phytoplankton.

When an algal bloom occurs within the metalimnion as was clearly the case in Fish Lake, surface profiles for Secchi depth, light intensity, nutrient concentration etc., are not affected. Although the algal biomass values may fall within in the range of what might be expected for a mesotrophic or eutrophic lake, the relatively low trophic state suggested by light and nutrient data may indicate a less productive system. It is probable that this is occurring in Fish Lake (personal communication with Jim Sweet)

\section{Indicator Species}

The dominant phytoplankton species present in each lake is a useful indicator of trophic state. Therefore, another phytoplankton trophic state model (Jim Sweet, Aquatic Analysts, Inc.) has been developed based on indicator 
species. Certain algae are commonly present in lakes of similar trophic classification. The 10 lakes of this study were classified using the Sweet model. This system assigns a trophic status value to a dominant algal species. These values were placed on a continuum from 1 (ultraoligotrophic) to 5 (hypereutrophic) (Sweet, 1986).

Anvil Lake had a dominance of Rhodomonas minuta on one sampling date. This alga is normally found in mesotrophic lakes. On another occasion, the dominant phytoplankton was an ochromas-like alga which is not considered an indicator.

Beaver Pond Lake had a dominance of Cryptomonas erosa, a mesotrophic indicator species, on one sampling occasion and Rhodomonas minuta, an oligotrophic indicator species on another.

Cripple Creek had a dominance of Rhodomonas minuta on two sampling occasions.

Fish Lake had dominant algal species which have not yet been given trophic state classification.

Gifford Lake had a dominance of Chromulina spp. (an oligotrophic indicator) on one occasion. On another occasion the dominant species was Glenodinium spp. Glenodinium is not an indicator species.

Monon Lake on one occasion had a dominant indicator species, Chromulina spp. This alga is considered an oligotrophic lake phytoplankter.

on no sampling occasion did Round Lake have a dominant 
indicator algal species.

Ollalie and Rimrock Lakes had a dominance of Chromulina spp. on two sampling occasions. As indicated previously, this is an oligotrophic lake indicator.

On one sampling trip Sportsman Lake contained a dominant indicator species, Chromulina spp. (APPENDIX C). Assigning a lake to a trophic status using indicator species is far from an exact science since species composition is in constant flux. For instance, in the case of Beaver Pond Lake, an oligotrophic indicator was dominant on one occcasion and a eutrophic indicator was dominant on another. An early summer sampling produced the oligotrophic species while a late summer sampling produced the eutrophic indicator.

Primary production and lake metabolism is constantly changing throughout the year. The presence or absence of particular organisms (phytoplankters or zooplankters) can be as much a function of seasonal variation as of trophic status.

\section{CHLOROPHYLL-A}

Another way of quantifying algal population densities is by determining the chlorophyll-a concentrations (Johnson et al., 1985). The lakes of this study were classified and ranked accordingly.

The average concentration of the chlorophyll-a in 
Beaver Pond Lake for 1991 was $29.3 \mathrm{ug} / \mathrm{L}$. This value falls well within the range of lakes considered eutrophic.

Round Lake had the next largest concentration with a value of $2.2 \mathrm{ug} / 1$. According to these data this lake is mesotrophic.

Cripple Creek, Sportsman, Fish, Anvil, and Rimrock Lakes are solidly oligotrophic systems, according to chlorophyll data, while Monon and ollalie are somewhere between ultra-oligotrophic and oligotrophic.

Gifford Lake is extremely unproductive with a chlorophyll-a a value of well below Carlson's 0.3 ug/l value given for ultraoligotrophic lakes (TABLE VI), (Carlson, 1977).

\section{ZOOPLANKTON}

Generalizations about lake metabolism can be made according to the densities (individuals $/ \mathrm{m}^{3}$ ) and the species composition of the zooplankters. The dynamics of the lake ecosystem are exemplified by relationships between phytoplankters, zooplankters and fish. These interactions are extremely complex and are beyond the scope of this study. However, a basic understanding of the zooplankter assemblages within these lakes may provide valuable information for future analyses (APPENDIX D).

The two major zooplankton groups encountered in these lakes are the cladocerans and the copepods. Therefore in this analysis generalizations will be made according to the 
presence of indicator species found in these zooplankter groups only.

Among the cladocerans, it is the members of the genus Daphnia which are considered as indicators. Daphnia rosea and D. galeata are indicative of oligotrophic-mestrophic lakes while Bosmina longirostris and Daphnia pulex are predominantly eutrophic lake indicators.

When focusing upon copepods, it is the ratio of Diaptomus to cyclops which is used as the trophic indicator. The higher this ratio, the more oligotrophic the lake.

Another criterion using zooplankton as an indicator of trophic status is zooplankter population density. Lakes with densities of less than 5000 individuals $/ \mathrm{m}^{3}$ are considered ultraoligotrophic while those with densities of 15000 individuals are considered eutrophic (personal communication; Allan Vogel).

The cladocerans present in Anvil Lake were Daphnia rosea (an oligotrophic indicator) and Bosmina longirostris (a eutrophic indicator). The Daphnia slightly outnumbered the Bosmina.

The Diaptomus/Cyclops ratio was $1: 9$ which suggests an oligotrophic lake. Diaptomus are filter feeding herbivores which have specific food particle size requirements best met in oligotrophic systems. Cyclops are carnivorous and do well in systems which are nutrient-rich. Finally, Diaptomus are fed upon by the cyclopoid copepods (Wetzel, 1983; Cole, 
1983; and personal communication with Allan Vogel).

The total density in Anvil Lake was 7289

individuals $/ \mathrm{m}^{3}$. On the basis of these data, this lake has relatively little biological productivity. As was inferred previously, generalizations as to trophic status based solely upon zooplankton data are unreliable.

A large population of Daphnia pulex (a eutrophic indicator) appeared in Beaver Pond Lake.

Although Cripple creek Lake has a relatively large Bosmina longirostris population (a eutrophic indicator), it also has a very high Diaptomus/Cyclops ratio, and the total density of phytoplankton is relatively low. Accordingly this lake is classified as oligo-mesotrophic.

Fish Lake has a relatively small Diaptomus/Cyclops ratio (indicative of eutrophic conditions) but because of its total density (10800 individuals $/ \mathrm{m}^{3}$ ) may be classified as mesotrophic.

Gifford Lake has species of zooplankters which are inconsistent with the Allan Vogel model. The total density values suggest that these lakes are ultraoligotrophic yet the Diaptomus/Cyclops ratio is relatively low. However, this lake had been stocked with fish, and fish predation upon the Daphnia may have reduced the numbers of this oligotrophic indicator species.

Monon Lake has relatively high concentrations of Daphnia galeata mendotae and Eubosmina hagmanni which is 
consistent with nutrient poor lakes. However, this lake has a relatively low Diaptomus/Cyclops ratio. Nevertheless, because of low total density of organisms, this lake is classified as oligotrophic. Values for total zooplankton density derived from mountain lake samples normally indicate that the system is nutrient poor. However, after a lake becomes extremely rich (highly eutrophic to hypereutrophic), the zooplankton density will decrease due to the nutrient overload, with its subsequent oxygen deficit (personal communication, Allan Vogel). After a lake has reached this trophic condition, blooms of algal species which are unpalatable to most zooplankters flourish. These are the gelatinous greens and blue-green algae (personal communication, Allan Vogel).

Ollalie Lake is nutrient-poor according to total zooplankton density values. Also, the presence of Daphnia rosea, Eubosmina hagmanni, and Daphnia galeata mendotae supports the assertion. Rimrock Lake has a relatively large population of planktonic herbivores (Diaptomus), no cyclopoid copepods and a moderate total density of individuals. Since there is no fish predation to interfere, it is likely that these data are representive of the lakes nutrient status.

Although Round Lake has relatively low total population density, it has a very low Diaptomus/Cyclops ratio. Also, due to the presence of a relatively large population of 
Daphnia pulex (another eutrophic indicator) this lake is probably mesotrophic to eutrophic.

sportsman Lake has the highest zooplankton population density of any of the lakes sampled but it also has a high Diaptomus/Cyclops ratio and there is a substantial population of Daphnia rosea. According to these data, this lake is likely an oligotrophic-mesotrophic system.

There is some evidence that lakes which are low in calcium have relatively large populations of the zooplankter Holopedium (Hutchinson, 1957; Cole 1983). A number of the lakes in this study have extremely low values for the cation.

In four of the lakes the concentrations of calcium (which is normally the predominant cation in mountain lakes) was lower than the concentration of sodium. Three of these lakes Gifford, ollalie, and Rimrock Lakes have extremely large populations of Holopedium while the Monon has a modest population of the zooplanter.

Holopedium was also found in Fish Lake and Round Lake. These lakes are not calcium poor. However, the population densities of this animal in Fish Lake and Round Lake were significantly smaller than the population densities of Gifford, Ollalie, and Rimrock Lakes.

Because lake conditions change continually and rapidly over the summer season, it is difficult to glean appreciable meaning from zooplankton data. Phytoplanktonic assemblages 
change continuously as do fish populations. Both variables affect zooplankter population size and species composition.

TROPHIC STATUS

It is a common convention to use trophic status for lake classification. In this study, the index published by Carlson in 1977, the phytoplankton index produced by Jim Sweet (based upon the Carlson index), and the Western Lake Survey data were the primary analytical tools (Wetzel, 1983; Landers, 1987; Sweet, 1986).

Each lake was classified to trophic state by each separate parameter. For example, Anvil Lake is eutrophic according to depth and watershed/surface area ratio, eutrophic according to nitrogen, phosphorus and silicate concentration, mesotrophic according to phytoplankton species composition, and oligotrophic according to phytoplankton density, chlorophyll concentration, and zooplankton density and species composition.

In this analysis, light extinction, nutrient concentration and chlorophyll concentrations were more heavily weighted since these parameters are considered the most reliable (Carlson, 1977).

The lakes have been rank-ordered from least to most productive and have been assigned a trophic status as follows: Ollalie Lake and Gifford Lake are ultraoligotrophic-to-oligotrophic; Monon and Rimrock Lakes are 
oligotrophic; Anvil, Cripple Creek, Fish, and Sportsman Lakes, are mesotrophic; Round Lake is mesotrophic-toeutrophic; and Beaver Pond Lake is eutrophic.

Fish, Monon, Ollalie, and Round Lakes have been previously studied. A comparison was made between the data sets obtained from the previous surveys (performed by the United States Forest Service) and those presented in this report. The previous surveys produced only limited data sets with which to compare.

since sampling techniques, laboratory techniques, and both sampling and laboratory equipment have become more sophisticated throughout the years, it can be difficult to draw reliable conclusions based upon comparisons over time. Also, without information related to the time of day that samples were taken and profiles performed, it is impossible to make direct comparisons. However, generalizations concerning the trends of the ecological processes over time are possible.

Fish Lake was surveyed in 1976 (Rinella, 1976). In 15 years the conductivity had increased approximately $26 \%$ while alkalinity had decreased 23\%. The secchi depth decreased approximately $15 \%$. The lake produced a negative heterograde oxygen curve in 1976. In 1991 and 1992, this lake produced a supersaturated metalimnion (positive heterograde oxygen profile). This lake has undergone significant change over the past 15 years. 
Monon Lake was surveyed in September of 1982 (Johnson, et al. 1985) These data were compared to the data obtained during the september 1991 sampling performed for this report. In 9 years the light extinction (versus depth) had increased $28 \%$. The chlorophyll-a concentration increased from $0.2 \mathrm{ug} . / \mathrm{L}$ to $0.3 \mathrm{ug} / \mathrm{L}$. The conductivity values have nearly tripled.

In 1982, Ollalie Lake was surveyed (Johnson et al. 1985). It was sampled in september and therefore was compared with data obtained from the september 1991 sampling from this survey.

In 9 years the Secchi depth of ollallie Lake decreased by $11 \%$ (approximately 1.4 meters). The concentration of chlorophyll-a increased from $0.3 \mathrm{ug} / \mathrm{L}$ to $0.5 \mathrm{ug} / \mathrm{L}$. The conductivity of the lake increased from 4 micromhos to 10 micromhos (TABLE V).

Round Lake was sampled in August of 1976 (Rinella, 1977). A comparison was made between the light and alkalinity data taken from that survey and data taken for this report during the same month of 1991. Both the Secchi depth and acid neutralizing capacity (alkalinity) decreased by $15 \%$ in the 15 year period.

Six of the lakes of this study were never previously investigated. The lakes are Anvil, Beaver Pond, Cripple Creek, Gifford, Rimrock, and Sportsman. The data compiled for this report will serve as baseline information for 
future lake monitoring.

Included in this report are clearcut maps of Anvil, Beaver Pond, Round, and Sportsman Lakes. Murphy (1981) and Carlson (1990) suggest that a significant change in stream macroinvertebrate species composition occurs as a result of clearcut logging (Murphy, 1981; Carlson, 1990). Since the streams feed the lake within the watershed, lake ecosystems could be affected.

However, Bormann (1979) suggests that as long as timber harvesting practices are performed in a responsible manner, no significant impact will occur.

Lake ecosystems evolve over the millenia. These changes are to be expected. Although changes which occur as the result of human use occur over a relatively short time span, with proper monitoring efforts, they can be remedied. Hopefully, the information in this report will be beneficial to that endeavor. 


\section{CONCLUSION}

Each lake surveyed was assigned a trophic status as follows: Ollalie and Gifford Lakes are ultraoligotrophicto-oligotrophic, Monon and Rimrock Lakes are oligotrophic, Anvil, Cripple Creek, Fish, and Sportsman Lakes are mesotrophic, Round Lake is mesoeutrophic, and Beaver Pond Lake is eutrophic.

It appears that biological productivity of these lakes has increased over the past 10-15 years. These lakes should by carefully monitored in the future.

Beaver Pond, Round, and Sportsman Lakes are nutrient rich while Monon, Ollalie, and Gifford are nutrient poor when compared to other lakes located within the Pacific Northwest. The other four lakes of this survey, Anvil, Cripple Creek, Fish, and Rimrock, have profiles which are expected for lakes located within the study area. 
REFERENCES

American Public Health Association, et al. 1976. Standard methods for the examination of water and wastewater. American Public Health Association, New York. 14th Edition. 1193 pp.

Baker, Lawrence A. 1991. Acidic lakes and streams in the United States: The role of acidic deposition. Science Reports, 252:1151-1153.

Bormann, F. H. 1979. Pattern and process in a forested ecosystem. Ecology textbook. Springer-Verlag publishers, Inc. Chapter 8, pp. 216-227.

Carlson, J.Y. 1990. Woody debris, channel features, and macroinvertebrates of streams with logged and undisturbed riparian timber in northwestern oregon, USA. Can. J. Fish. Aquat. Sci. 47-2:1103-1111.

Carlson, Robert E. 1977. A trophic state index for lakes. Limno. and oceanog. 22-2:361-370.

Carver, Gary A. 1973. Glacial geology of mountain lakes, wilderness and adjacent parts of the Cascade range, oregon. Ph. D. Dissertation. University of Washington.

Chow-Fraser, Patricia. 1991. Use of the morphoedaphic index to predict nutrient status and algal biomass in some Canadian lakes. Can. J. Fish. Aquat. Sci. 48: 1909-1918.

Cole, Gerald A. 1979. Textbook of limnology. 2nd Edition. C.V. Mosby Company. 426 pp.

Cole, Gerald A. 1983. Textbook of limnology. 3rd Edition. Waverland Press, Inc. 401 pp.

Hutchinson, G.E. 1957. A treatise on limnology. Vol. I. Geography, physics, and chemistry. New York, John Wiley \& Sons, Inc. $1015 \mathrm{pp}$.

Jackson, Donald A., H.H. Harvey, K.M. somers. 1990 . Ratios in aquatic sciences:shortcomings with mean depth and the morphoedaphic index. Can. J. Aquat. Sci. 47 : 1788-1795. 
Johnson, Daniel M., R.R. Petersen, D.R. Lycan, J.W. Sweet, M.E. Neuhaus. 1985. Atlas of Oregon lakes. Oregon State University Press. Corvallis, Oregon. $317 \mathrm{pp}$.

Kelly, Valerie J. 1992. Limnology of two new lakes, Mount st. Helens, Washington. Thesis. Portland state University. $173 \mathrm{pp}$.

Landers, D.H., J.M. Eilers, D.F. Brakke, W.S. Overton, P.E. Kellar, M.E. silverstein, R.D. Schonbrod, R.E. Crowe, R.A. Linthrust, J.M. Omernik, S.A. Teague, E.P. Meier. 1987. United States Environmental Protection Agency western lake survey. Phase I. Characteristics of lakes in the western United States. Volume 1. $176 \mathrm{pp}$.

McHugh, Robert A. 1972. An interim study of some physical, chemical, and biolgical properties of selected oregon lakes. Oregon state Department of Environmental Quality. $109 \mathrm{pp}$.

Murphy, Michael L. 1981. Varied effect of clear-cut logging on predators, and their habitat in small streams of the Cascade Mountains of oregon. Can. J. Fish. Aquat. Sci. $38: 137-145$.

Petersen, Richard R. 1992. Lakes of the Mount st. Helens National Forest. Final report to Peter Frenzen, chief scientist, Mount St. Helens National Monument.

Rinella, Joseph. 1977. Lakes of Oregon. Department of the Interior, United States Geological Survey. Oregon District, Portland, Oregon. Open file report. Volume 4 .

Ryder, R.A. 1974. The morphoedaphic index, a fish yield estimator--review and evaluation. J. Fish. Res. Board Can. 31:663-688.

Scott, William E. 1990. Field trip guide to the central Oregon high Cascades. Part 1: Mount Bachelor-South Sister area.

Sweet, Jim W. 1986. A survey and ecological analysis of oregon and Idaho phytoplankton.

Wetzel, Robert G. 1979. Limnological analysis. W.B. Saunders Co. 357 pp.

Wetzel, Robert G. 1983. Limnology. 2nd Edition. Saunders College Publishing. $767 \mathrm{pp}$. 
APPENDIX A

DETAILED DIRECTIONS INTO EACH LAKE 
SPECIFIC DIRECTIONS FROM RIPPLEBROOK RANGER STATION (RRS)

\section{ANVIL LAKE}

Anvil Lake is reached by traveling east on OSH 224 for approximately $1.6 \mathrm{~km}$ (1 $\mathrm{mi}$ ) to National Forest Primary Route (NFPR) 57, and then east on NFPR 57 to NFPR 58. Route 58 is taken north for approximately $2.4 \mathrm{~km}(1.5 \mathrm{mi})$ to Forest Route (FR) 5810. One turns right on to FR 5810 which is taken for approximately $8 \mathrm{~km}$ ( $5 \mathrm{mi}$ ) to FR 5820.5820 is taken north $5.6 \mathrm{~km}(3.5 \mathrm{mi})$ to Anvil Creek where there is an automobile pull-off. There is no maintained trail to the lake. Access requires a short hike [approx. $0.40 \mathrm{~km}(1 / 4$ mi)] up Anvil Creek (Figure 2).

\section{BEAVER POND}

Beaver Pond Lake is reached by traveling from RRS. approximately $1.6 \mathrm{~km}$ ( $1 \mathrm{mi}$ ) to OSH 46 . Oregon State Highway 46 is taken south approximately $7 \mathrm{~km}(4.4 \mathrm{miles})$ to Forest Route (FR) 6310. At FR 6310 one turns left and travels approximately $3.2 \mathrm{~km}$ ( 2 miles) to $\mathrm{FR} 6311$ which is taken to the left. 6311 is taken for approximately $4 \mathrm{~km}(2.5 \mathrm{mi})$ to Spur Road 140. The spur is taken for a distance of approximately $0.32 \mathrm{~km}(0.2 \mathrm{mi})$ to the lake, which is approximately $9 \mathrm{~m}(30 \mathrm{y})$ off of the road to the right (Figure 2).

\section{CRIPPLE CREEK}

To reach Cripple creek Lake, take FR 4631 east from RRS approximately $4.8 \mathrm{~km}$ ( 3 miles) to F.R. 4630.4630 is 
taken east for approx. $3.6 \mathrm{~km} \mathrm{(1} \mathrm{mile)} \mathrm{to} \mathrm{F.R.} 4635.4635$ is taken to the left and travelled for approximately $17 \mathrm{~km}$ (11 $\mathrm{mi}$ ) to SR 140. The trailhead is located where SR 140 crosses Cripple creek. This is approximately $3.2 \mathrm{~km}$ (2 $\mathrm{mi})$ off of FR 4635 on SR 140 (Figure 2).

FISH LAKE

Fish Lake may be reached by traveling from RRS approximately $1.6 \mathrm{~km}(1 \mathrm{mi})$ to $\mathrm{OSH} 46$. One turns right on highway 46 which is travelled for approximately $24 \mathrm{~km}$ (15 mi) where OSH 42 branches off. Highway 42 is taken for approximately $1.6 \mathrm{~km}$ (1 $\mathrm{mi})$ to FR 4230 , the Ollalie Lake Junction (OLJ). 4230 is taken to the left and travelled for approximately $8 \mathrm{~km} \mathrm{(5} \mathrm{mi)} \mathrm{to} \mathrm{FR} \mathrm{4220.} 4220$ is then taken

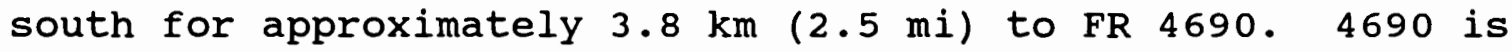
taken west for approximately $6.4 \mathrm{~km}$ (4 mi) to FR 4691.4691 is taken in a southeasterly direction approximately $4.8 \mathrm{~km}$ ( $3 \mathrm{mi}$ ), under a conspicuous set of electrical power lines, and finally, down a steep hill that curves to the right at the trail head.

Access to Fish Lake requires a hike of approximately a mile. The steep trail off of FR 4691 affords a quick descent to the lake. At the trails end (on the northside of the lake) is a campsite with a picnic table (see Figure 2). GIFFORD LAKE

Gifford Lake may be reached by traveling from RRS southeast to FR 4220 via the same route as was outlined for 
Fish Lake. 4220 is taken for approximately $12 \mathrm{~km}(7.5 \mathrm{mi})$ to the Lower Lake Campground which is approximately $3.2 \mathrm{~km}$ (2 mi) from ollalie Lake. The trail to Gifford Lake begins at the west end of the campground.

Access to the lake requires a hike-in of just under an hour. USFS trail 717 (from the campground) is taken to USFS trail 706. 706 is taken west for approximately $800 \mathrm{~m}$ (0.50 mi). Off trail 706 is the Gifford Lake Trail which follows the ridgeline in a southeasterly direction. The Gifford Lake Trail is approximately $0.50 \mathrm{~km}(.31 \mathrm{mi})$ long (Figure 8)

\section{MONON AND OLLALIE LAKES}

Monon and ollalie Lakes may be reached by traveling from RRS to Forest Route 4220 south past the Lower Lake Campground (as was previously described) for approximately $4.8 \mathrm{~km}(3 \mathrm{mi})$. The lake is immediately off of FR 4220 approximately $1.6 \mathrm{~km}$ (1 $\mathrm{mi})$ south of ollalie Lake which is also on FR 4220 .

RIMROCK LAKE

Rimrock Lake is reached by first traveling to ollalie Lake (directions previously described in the Monon Lake section of this paper). At the north end of ollalie Lake, the Pacific Crest Trail can be accessed.

Rimrock Lake is difficult to find since there is no maintained trail to the lake. Access is via the Pacific Crest and Red Lake trails. The lake can be reached by 
leaving the Red Lake Trail approximately $0.8 \mathrm{~km}(0.5 \mathrm{mi})$ northwest of the Pacific Crest Trail/Red Lake Trail junction, and traveling southeast (downhill) for approximately 0.4 to $0.8 \mathrm{~km}(0.25$ to $0.5 \mathrm{mi})$. There are a few game trails through this heavily forested area. The total hiking time from the Pacific crest Trail access point at ollalie Lake to Rimrock Lake is approximately 1 hour and 15 minutes.

ROUND LAKE

Round Lake may be reached by driving east from RRS approximately $1.6 \mathrm{~km}(1 \mathrm{mi})$ to OSH 46 . This highway is taken south for approximately $5.6 \mathrm{~km}(3.5 \mathrm{mi})$ to osH 63.63 is taken south for approximately $21.6 \mathrm{~km}(13.5 \mathrm{mi})$ to FR 6370. 6370 is taken south for approximately $11.2 \mathrm{~km}$ (7 $\mathrm{mi})$ to the Round Lake trailhead where there is an automobile pulloff. The trail begins on the uphill (left) side of the road. The trailhead is well marked. The hike into the lake takes approximately 15 minutes. SPORTSMAN LAKE

Sportsman Lake may be reached by taking oregon state Highway 46 which as stated previously begins approximately

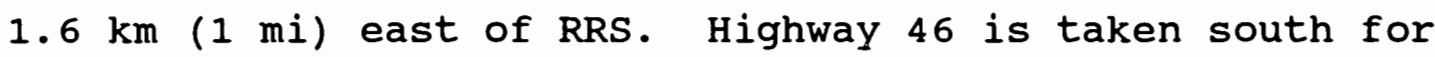
approximately $46.4 \mathrm{~km}(29.5 \mathrm{mi})$ to $\mathrm{FR} 6350$ west. 6350 is

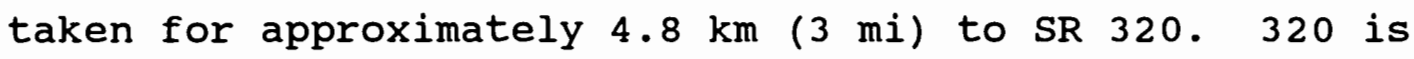
taken southeast for approximately $3.2 \mathrm{~km} \mathrm{(2} \mathrm{mi)} \mathrm{to} \mathrm{SR} 340$. One turns right on $S R 340$ and it is followed until it 
deadends at approximately $0.40 \mathrm{~km}(0.25 \mathrm{mi})$. Access to Sportsman Lake is difficult since there is no maintained trail. The easiest access requires a hike of approximately $0.8 \mathrm{~km}(0.5 \mathrm{mi})$ across a clearcut and burned area, located just off SR 340 . 


\section{APPENDIX B}

TEMPERATURE AND DISSOLVED OXYGEN DATA 
TEMPERATURE AND DISSOLVED OXYGEN

\begin{tabular}{|c|c|c|}
\hline $\begin{array}{l}\text { DEPTH } \\
\text { (m) }\end{array}$ & $\begin{array}{l}\text { TEMPERATURE } \\
\text { (C) }\end{array}$ & $\begin{array}{c}\text { DISSOLVED OXYGEN } \\
(\mathrm{mg} / \mathrm{L})\end{array}$ \\
\hline 0.00 & $\begin{array}{l}19.1 \\
19.0\end{array}$ & $\begin{array}{l}8.68 \\
7.23\end{array}$ \\
\hline $\begin{array}{l}0.50 \\
0.75 \\
1.00\end{array}$ & $\begin{array}{l}18.9 \\
18.7 \\
18.4\end{array}$ & $\begin{array}{l}6.78 \\
7.13 \\
6.84\end{array}$ \\
\hline
\end{tabular}

ANVIL LAKE

AUGUST 22, 1991

\begin{tabular}{ccc}
$\begin{array}{c}\text { DEPTH } \\
(\mathrm{m})\end{array}$ & $\begin{array}{c}\text { TEMPERATURE } \\
(\mathrm{C})\end{array}$ & $\begin{array}{c}\text { DISSOLVED OXYGEN } \\
(\mathrm{mg} / \mathrm{L})\end{array}$ \\
\hline 0.00 & 22.9 & 7.9 \\
0.25 & 22.8 & 7.8 \\
0.50 & 22.1 & 7.8 \\
0.75 & 21.2 & 7.7 \\
1.00 & 21.1 & 7.6 \\
1.25 & 21.1 & 7.9
\end{tabular}

WINKLER OXYGEN TITRATION (WOT): 1-METER $8.20 \mathrm{mg} / \mathrm{L}$ REPLICA (REP) $9.20 \mathrm{mg} / \mathrm{L}$

ANVIL LAKE

JULY 4, 1992

\begin{tabular}{|c|c|c|}
\hline $\begin{array}{l}\text { DEPTH } \\
(\mathrm{m})\end{array}$ & $\begin{array}{l}\text { TEMPERATURE } \\
\text { (C) }\end{array}$ & $\begin{array}{l}\text { DISSOLVED OXYGEN } \\
(\mathrm{mg} / \mathrm{L})\end{array}$ \\
\hline $\begin{array}{l}0.00 \\
0.25\end{array}$ & $\begin{array}{l}18.0 \\
18.0\end{array}$ & $\begin{array}{l}8.07 \\
8.00\end{array}$ \\
\hline 0.50 & 18.0 & 7.95 \\
\hline 0.75 & 18.0 & 8.96 \\
\hline 1.00 & 17.5 & 7.60 \\
\hline 1.25 & 17.1 & 7.60 \\
\hline 1.50 & 17.0 & 8.05 \\
\hline
\end{tabular}

WOT: 1-METER $6.80 \mathrm{mg} / \mathrm{L}$

BEAVER POND LAKE

JUNE 24, 1991

DEPTH 


\begin{tabular}{ccc}
$(\mathrm{m})$ & $(\mathrm{C})$ & $(\mathrm{mg} / \mathrm{L})$ \\
\hline 0.00 & 15.6 & 6.50 \\
0.50 & 15.0 & 6.30 \\
1.00 & 15.0 & 5.30 \\
1.50 & 14.4 & 5.40 \\
2.00 & 14.0 & 5.50 \\
2.50 & 12.5 & 2.24 \\
3.00 & 11.9 & 1.10
\end{tabular}

BEAVER POND LAKE

AUGUST 23， 1991

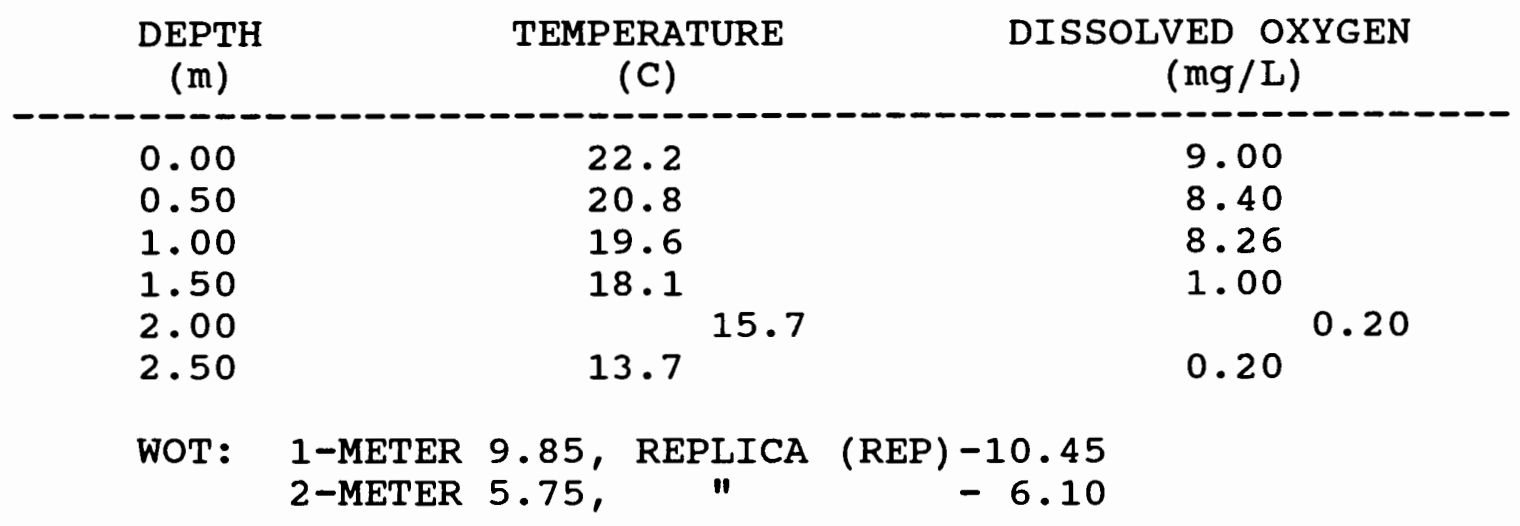

BEAVER POND LAKE

OCTOBER 25, 1991

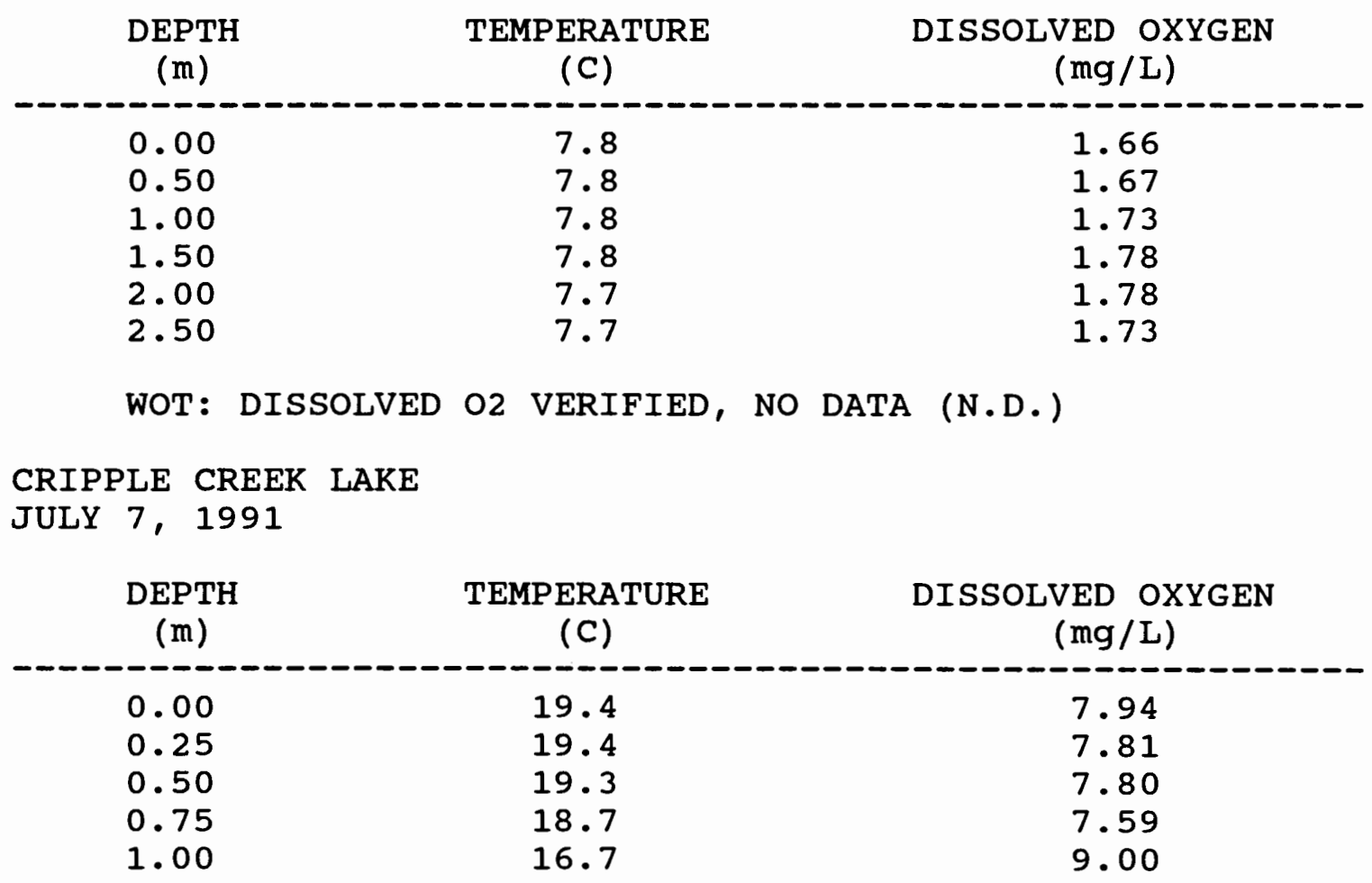


CRIPPLE CREEK LAKE

AUGUST 21, 1991

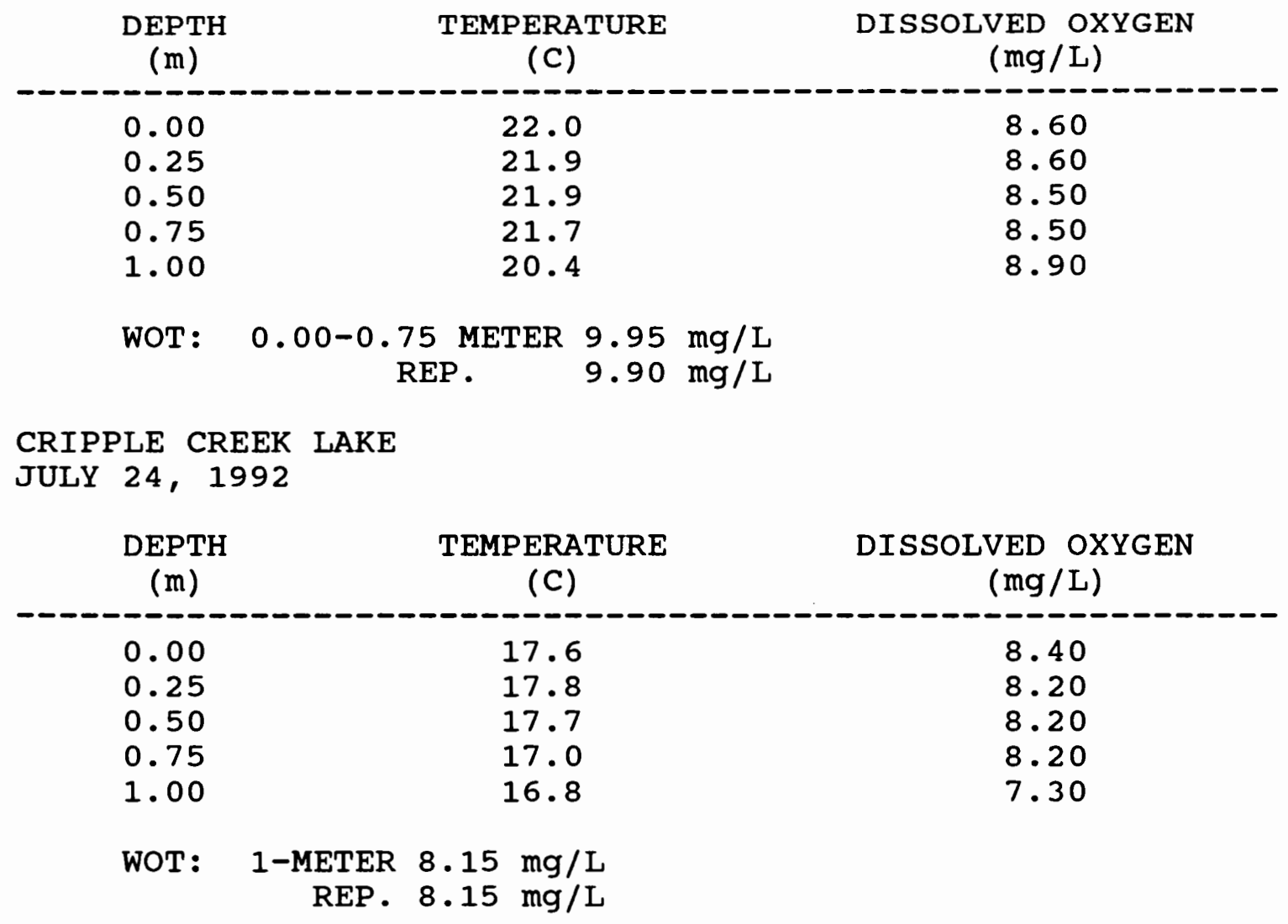

FISH LAKE

JULY 1, 1991

\begin{tabular}{crr}
$\begin{array}{c}\text { DEPTH } \\
(\mathrm{m})\end{array}$ & $\begin{array}{r}\text { TEMPERATURE } \\
(\mathrm{C})\end{array}$ & $\begin{array}{c}\text { DISSOLVED OXYGEN } \\
(\mathrm{mg} / \mathrm{L})\end{array}$ \\
\hline 0.00 & 16.5 & 8.94 \\
1.00 & 15.4 & 8.84 \\
2.00 & 14.0 & 9.35 \\
3.00 & 13.7 & 9.36 \\
4.00 & 12.8 & 10.30 \\
5.00 & 11.0 & 11.90 \\
6.00 & 9.1 & 13.00 \\
7.00 & 7.0 & 12.69 \\
8.00 & 6.2 & 11.20 \\
9.00 & 5.7 & 11.10 \\
10.00 & 5.4 & 9.50 \\
11.00 & 5.1 & 8.11 \\
12.00 & 4.7 & 7.43 \\
13.00 & 4.6 & 5.14 \\
14.00 & 4.5 & 3.77 \\
15.00 & 4.3 & 2.30
\end{tabular}




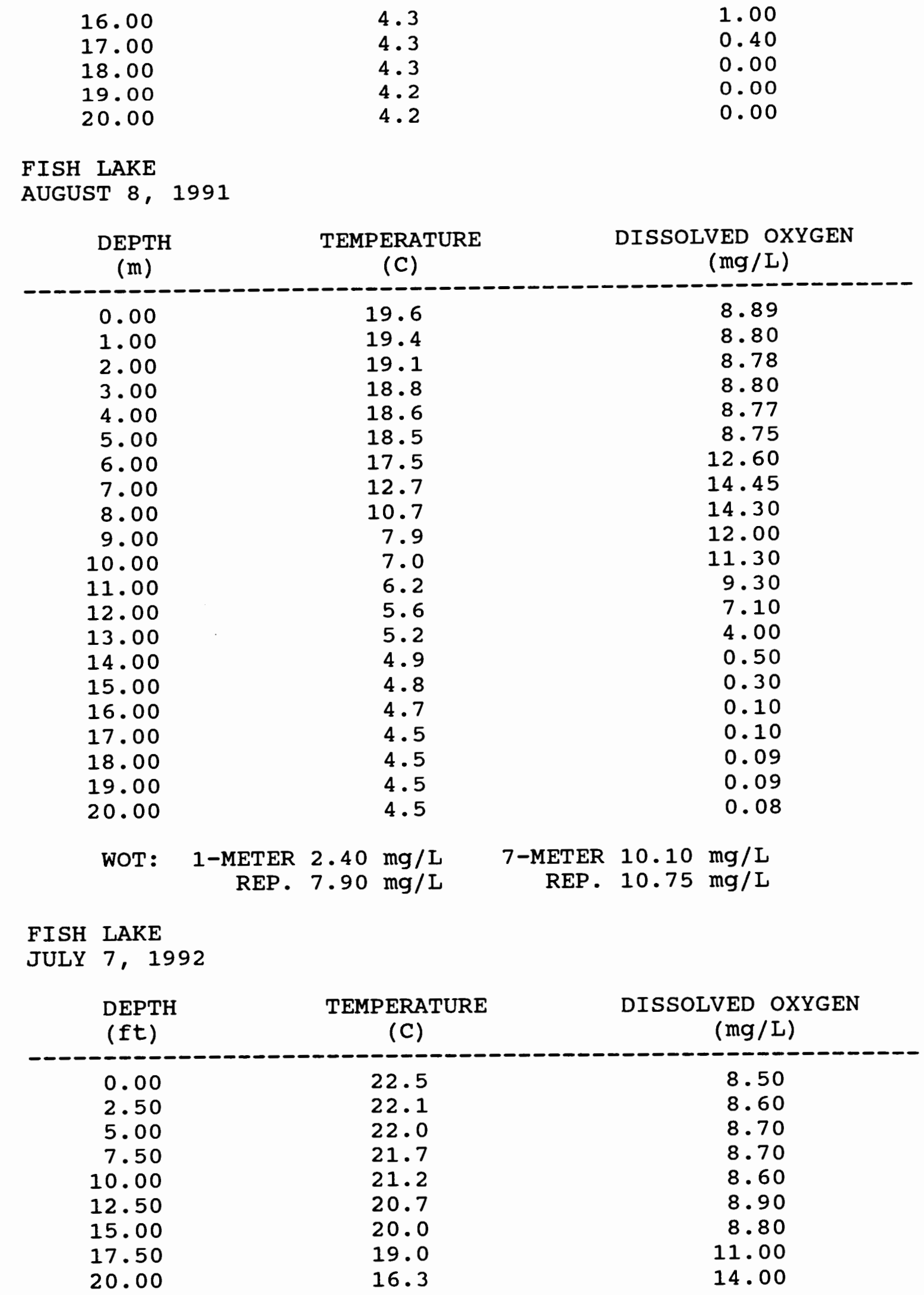




$\begin{array}{rrr}22.50 & 13.0 & 14.20 \\ 25.00 & 10.6 & 14.00 \\ 27.50 & 9.2 & 13.00 \\ 30.00 & 8.1 & 11.60 \\ 32.50 & 7.2 & 10.00 \\ 35.00 & 6.6 & 8.60 \\ 37.50 & 6.0 & 6.10 \\ 40.00 & 5.4 & 3.60 \\ 42.50 & 5.2 & 1.40 \\ 45.00 & 5.0 & 0.40 \\ 47.50 & 5.0 & 0.09 \\ 50.00 & 4.9 & 0.05\end{array}$

WOT: 1-METER $6.60 \mathrm{mg} / \mathrm{L}$ 7-METER $10.90 \mathrm{mg} / \mathrm{L}$ REP. $7.45 \mathrm{mg} / \mathrm{L}$ 7-METER $10.90 \mathrm{mg} / \mathrm{L}$

GIFFORD LAKE

JULY 2, 1991

\begin{tabular}{ccc}
$\begin{array}{c}\text { DEPTH } \\
(\mathrm{m})\end{array}$ & $\begin{array}{c}\text { TEMPERATURE } \\
(\mathrm{C})\end{array}$ & $\begin{array}{c}\text { DISSOLVED OXYGEN } \\
(\mathrm{mg} / \mathrm{L})\end{array}$ \\
\hline 0.00 & 16.4 & 8.60 \\
1.00 & 14.3 & 8.99 \\
2.00 & 13.2 & 8.88 \\
3.00 & 12.7 & 9.00 \\
4.00 & 12.2 & 8.90 \\
5.00 & 11.3 & 9.07 \\
10.00 & 7.4 & 9.33 \\
15.00 & 6.6 & 9.37
\end{tabular}

GIFFORD LAKE

AUGUST 29, 1991

\begin{tabular}{ccc}
$\begin{array}{c}\text { DEPTH } \\
(\mathrm{m})\end{array}$ & $\begin{array}{c}\text { TEMPERATURE } \\
(\mathrm{C})\end{array}$ & $\begin{array}{c}\text { DISSOLVED OXYGEN } \\
(\mathrm{mg} / \mathrm{L})\end{array}$ \\
\hline 0.00 & 18.1 & 7.90 \\
1.00 & 17.9 & 7.80 \\
2.00 & 17.9 & 7.74 \\
3.00 & 17.9 & 7.72 \\
4.00 & 17.9 & 7.70 \\
5.00 & 17.8 & 7.70 \\
6.00 & 17.8 & 7.68 \\
7.00 & 17.8 & 7.70 \\
8.00 & 17.8 & 7.68 \\
9.00 & 17.2 & 7.68 \\
10.00 & 17.0 & 10.20 \\
11.00 & 14.6 & 10.45 \\
12.00 & 13.3 & 10.55 \\
13.00 & 12.9 & 10.69 \\
14.00 & 12.6 & 10.80
\end{tabular}




\begin{tabular}{|c|c|c|c|c|}
\hline $\begin{array}{l}15.00 \\
16.00 \\
17.00 \\
18.00\end{array}$ & & $\begin{array}{l}12.4 \\
12.3 \\
12.4 \\
12.4\end{array}$ & & $\begin{array}{r}10.75 \\
10.24 \\
9.20 \\
7.50\end{array}$ \\
\hline $\begin{array}{l}\text { WOT: 1-METER } \\
\text { REP. }\end{array}$ & $\begin{array}{l}7.20 \\
7.50\end{array}$ & $\begin{array}{l}\mathrm{mg} / \mathrm{L} \\
\mathrm{mg} / \mathrm{L}\end{array}$ & $\begin{array}{c}\text { 11-METER } \\
\text { REP. }\end{array}$ & $\begin{array}{l}8.95 \mathrm{mg} / \mathrm{L} \\
9.50 \mathrm{mg} / \mathrm{L}\end{array}$ \\
\hline $\begin{array}{l}\text { GIFFORD } \\
\text { JULY } 17, \quad 1992\end{array}$ & & & & \\
\hline $\begin{array}{l}\text { DEPTH } \\
(\mathrm{m})\end{array}$ & \multicolumn{3}{|c|}{$\begin{array}{l}\text { TEMPERATURE } \\
\text { (C) }\end{array}$} & $\begin{array}{c}\text { DISSOLVED OXYGEN } \\
(\mathrm{mg} / \mathrm{L})\end{array}$ \\
\hline $\begin{array}{r}0.00 \\
1.00 \\
2.00 \\
3.00 \\
4.00 \\
5.00 \\
6.00 \\
7.00 \\
8.00 \\
9.00 \\
10.00 \\
11.00 \\
12.00 \\
13.00 \\
14.00 \\
15.00 \\
16.00 \\
17.00 \\
18.00\end{array}$ & \multicolumn{3}{|c|}{$\begin{array}{l}21.4 \\
19.6 \\
19.0 \\
18.8 \\
18.6 \\
18.5 \\
18.4 \\
18.3 \\
18.2 \\
17.1 \\
15.0 \\
13.4 \\
13.0 \\
12.0 \\
12.0 \\
12.0 \\
12.0 \\
12.0 \\
12.0\end{array}$} & $\begin{array}{r}8.60 \\
9.05 \\
9.40 \\
9.40 \\
9.40 \\
9.20 \\
9.03 \\
8.90 \\
8.80 \\
10.20 \\
11.00 \\
11.20 \\
11.40 \\
11.40 \\
11.50 \\
11.20 \\
10.40 \\
9.80 \\
9.30\end{array}$ \\
\hline WOT: 1-METER & 5.95 & $\mathrm{mg} / \mathrm{L}$ & \multirow[t]{2}{*}{ 11-METER } & $9.05 \mathrm{mg} / \mathrm{L}$ \\
\hline $\begin{array}{l}\text { MONON LAKE } \\
\text { JUNE } 29,1991\end{array}$ & & & & \\
\hline $\begin{array}{l}\text { DEPTH } \\
(\mathrm{m})\end{array}$ & \multicolumn{3}{|c|}{$\begin{array}{l}\text { TEMPERATURE } \\
\text { (C) }\end{array}$} & $\begin{array}{c}\text { DISSOLVED OXYGEN } \\
(\mathrm{mg} / \mathrm{L})\end{array}$ \\
\hline $\begin{array}{r}0.00 \\
5.00 \\
10.00\end{array}$ & \multicolumn{3}{|c|}{$\begin{array}{r}13.4 \\
12.1 \\
8.5\end{array}$} & $\begin{array}{r}8.70 \\
9.00 \\
10.50\end{array}$ \\
\hline \multicolumn{5}{|l|}{$\begin{array}{l}\text { MONON LAKE } \\
\text { SEPTEMBER 1, } 1991\end{array}$} \\
\hline $\begin{array}{l}\text { DEPTH } \\
(\mathrm{m})\end{array}$ & \multicolumn{3}{|c|}{$\begin{array}{l}\text { TEMPERATURE } \\
\text { (C) }\end{array}$} & $\begin{array}{c}\text { DISSOLVE OXYGEN } \\
(\mathrm{mg} / \mathrm{L})\end{array}$ \\
\hline
\end{tabular}




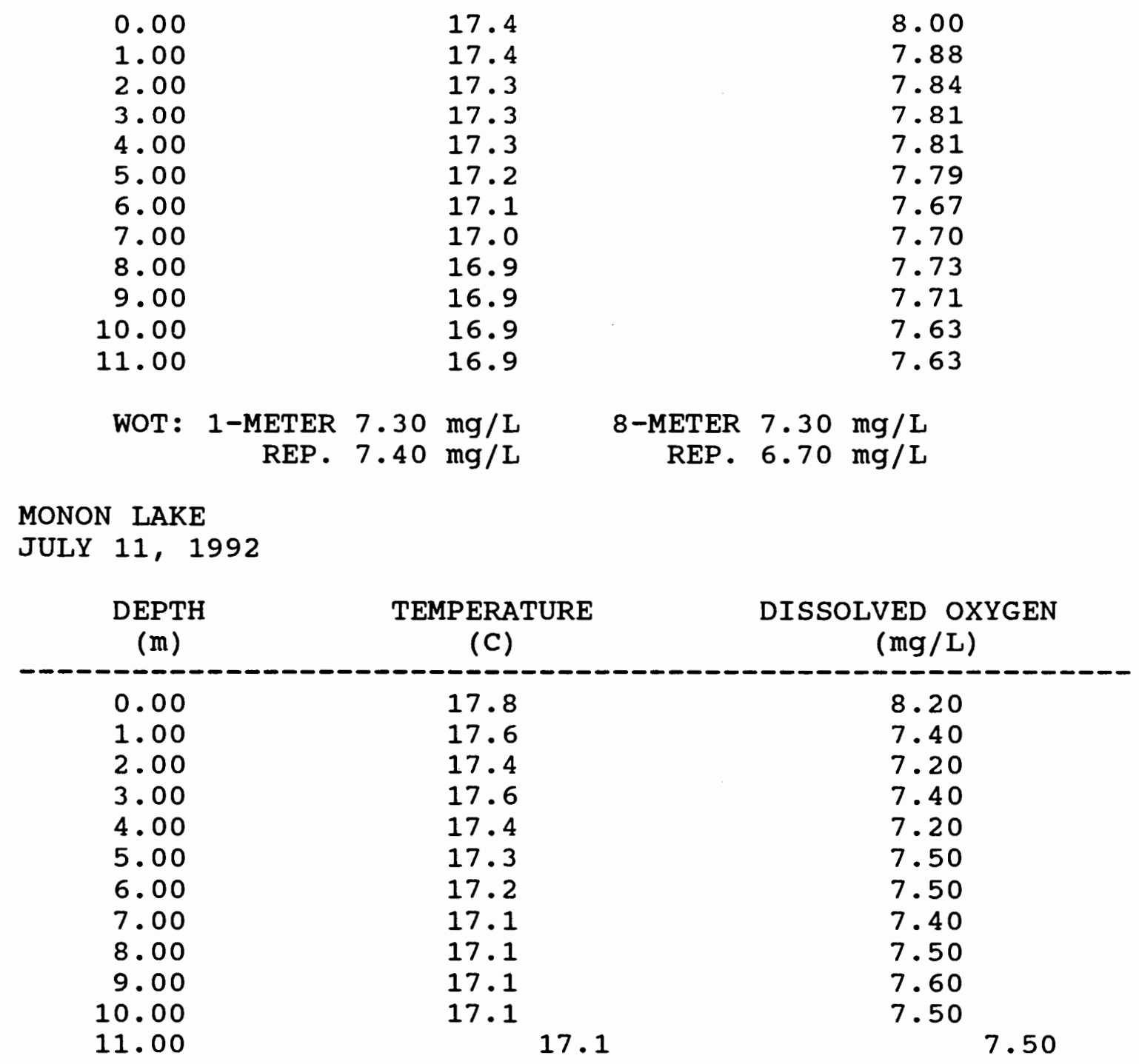

WOT: 1-METER $6.55 \mathrm{mg} / \mathrm{L}$

REP. $6.90 \mathrm{mg} / \mathrm{L}$

OLLALIE LAKE

JUNE 30,1991

DEPTH

(m)

0.00

2.50

5.00

7.50

10.00
TEMPERATURE

(C)

12.6

12.5

12.0

12.0

11.3
DISSOLVED OXYGEN

$(\mathrm{mg} / \mathrm{L})$

8.46

9.20

8.58

9.30

8.61

OLLALIE LAKE 
SEPTEMBER 2， 1991

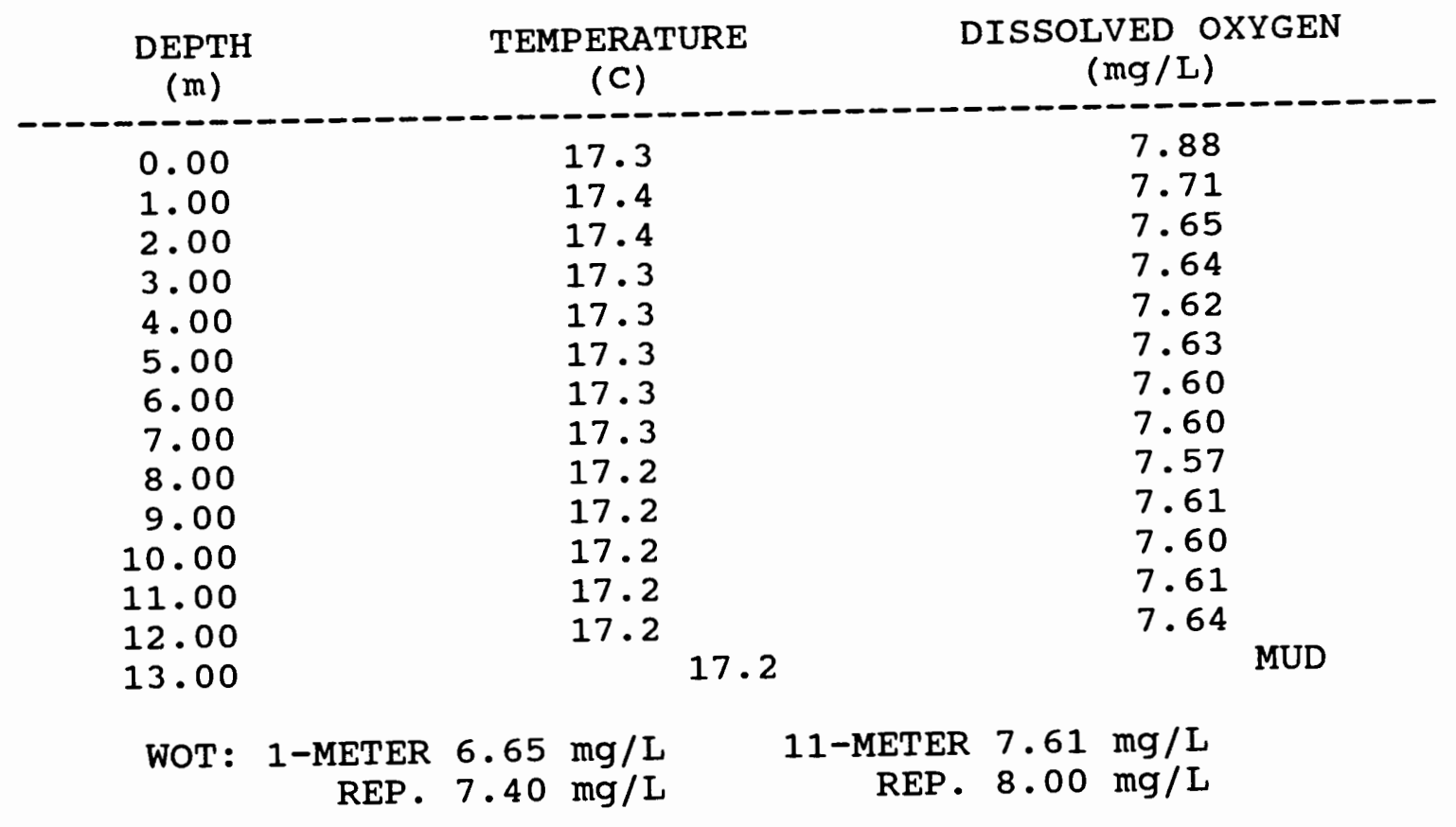

OLLALIE LAKE

JULY 16, 1992

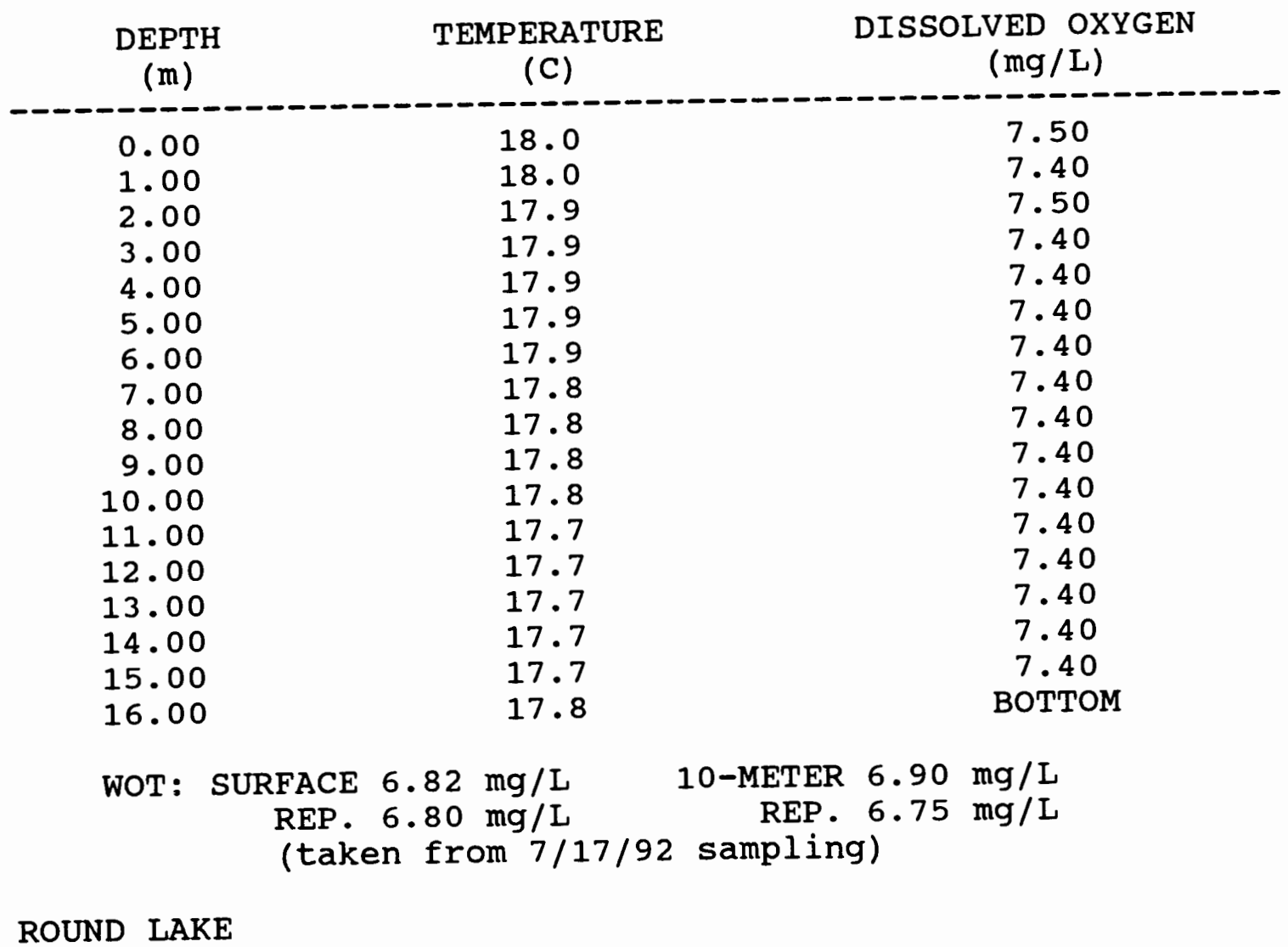


JULY 8, 1991

\begin{tabular}{ccc}
$\begin{array}{c}\text { DEPTH } \\
(\mathrm{m})\end{array}$ & $\begin{array}{r}\text { TEMPERATURE } \\
(\mathrm{C})\end{array}$ & $\begin{array}{r}\text { DISSOLVED OXYGEN } \\
(\mathrm{mg} / \mathrm{L})\end{array}$ \\
\hline 0.00 & 20.6 & 8.57 \\
1.00 & 18.2 & 9.31 \\
2.00 & 14.8 & 10.62 \\
3.00 & 12.9 & 10.92 \\
4.00 & 11.5 & 11.00 \\
5.00 & 10.5 & 11.04 \\
6.00 & 9.6 & 11.50
\end{tabular}

ROUND LAKE

AUGUST 24, 1991

\begin{tabular}{ccc}
$\begin{array}{c}\text { DEPTH } \\
(\mathrm{m})\end{array}$ & $\begin{array}{r}\text { TEMPERATURE } \\
(\mathrm{C})\end{array}$ & $\begin{array}{r}\text { DISSOLVED OXYGEN } \\
(\mathrm{mg} / \mathrm{L})\end{array}$ \\
\hline 0.00 & 20.2 & 9.10 \\
1.00 & 20.0 & 9.10 \\
2.00 & 19.1 & 10.30 \\
3.00 & 17.5 & 11.50 \\
4.00 & 16.4 & 11.50 \\
5.00 & 15.5 & 12.40 \\
6.00 & 13.9 & 11.50 \\
7.00 & 12.5 & 7.20 \\
WOT: 1 -METER $11.65 \mathrm{mg} / \mathrm{L}$ & 6-METER $12.20 \mathrm{mg} / \mathrm{L}$ \\
REP. $10.10 \mathrm{mg} / \mathrm{L}$ & REP. $11.60 \mathrm{mg} / \mathrm{L}$
\end{tabular}

ROUND LAKE

JULY 3， 1992

\begin{tabular}{ccc}
$\begin{array}{c}\text { DEPTH } \\
(\mathrm{m})\end{array}$ & $\begin{array}{c}\text { TEMPERATURE } \\
(\mathrm{C})\end{array}$ & $\begin{array}{c}\text { DISSOLVED OXYGEN } \\
(\mathrm{mg} / \mathrm{L})\end{array}$ \\
\hline 0.00 & 19.9 & 9.02 \\
1.00 & 18.5 & 8.73 \\
2.00 & 17.7 & 9.32 \\
3.00 & 16.5 & 11.34 \\
4.00 & 15.5 & 10.75 \\
5.00 & 14.8 & 11.81 \\
6.00 & 13.1 & 11.74 \\
7.00 & 11.1 & $2.3-5 ?$ \\
8.00 & 9.4 & 0.30 \\
WOT: 1-METER $8.85 \mathrm{mg} / \mathrm{L}$ & 5-METER $9.90 \mathrm{mg} / \mathrm{L}$ \\
REP. 7.40 mg/L & REP. 10.40 mg/L \\
RIMROCK LAKE & & \\
JULY 3, 1991 & &
\end{tabular}




\begin{tabular}{ccc}
$\begin{array}{c}\text { DEPTH } \\
(\mathrm{m})\end{array}$ & $\begin{array}{c}\text { TEMPERATURE } \\
(\mathrm{C})\end{array}$ & $\begin{array}{c}\text { DISSOLVED OXYGEN } \\
(\mathrm{mg} / \mathrm{L})\end{array}$ \\
\hline 0.00 & 18.8 & 7.80 \\
0.50 & 17.8 & 8.00 \\
1.00 & 16.8 & 8.00 \\
1.50 & 16.3 & 8.40 \\
2.00 & 16.0 & 8.00 \\
2.50 & 15.9 & 8.40 \\
3.00 & 15.7 & 8.40
\end{tabular}

RIMROCK LAKE

AUGUST 30, 1991

\begin{tabular}{ccc}
$\begin{array}{c}\text { DEPTH } \\
(\mathrm{m})\end{array}$ & $\begin{array}{r}\text { TEMPERATURE } \\
(\mathrm{C})\end{array}$ & $\begin{array}{c}\text { DISSOLVED OXYGEN } \\
(\mathrm{mg} / \mathrm{L})\end{array}$ \\
\hline 0.00 & 15.9 & 7.32 \\
0.50 & 16.1 & 7.19 \\
1.00 & 16.1 & 7.12 \\
1.50 & 16.1 & 7.08 \\
2.00 & 16.1 & 7.15 \\
2.50 & 16.1 & 7.16 \\
3.00 & 16.0 & 7.15 \\
WOT: & & \\
& RETER $7.35 \mathrm{mg} / \mathrm{L}$ & 2-METER $8.10 \mathrm{mg} / \mathrm{L}$ \\
& $7.60 \mathrm{mg} / \mathrm{L}$ & REP. 7.60 $\mathrm{mg} / \mathrm{L}$
\end{tabular}

RIMROCK LAKE

JULY 16, 1992

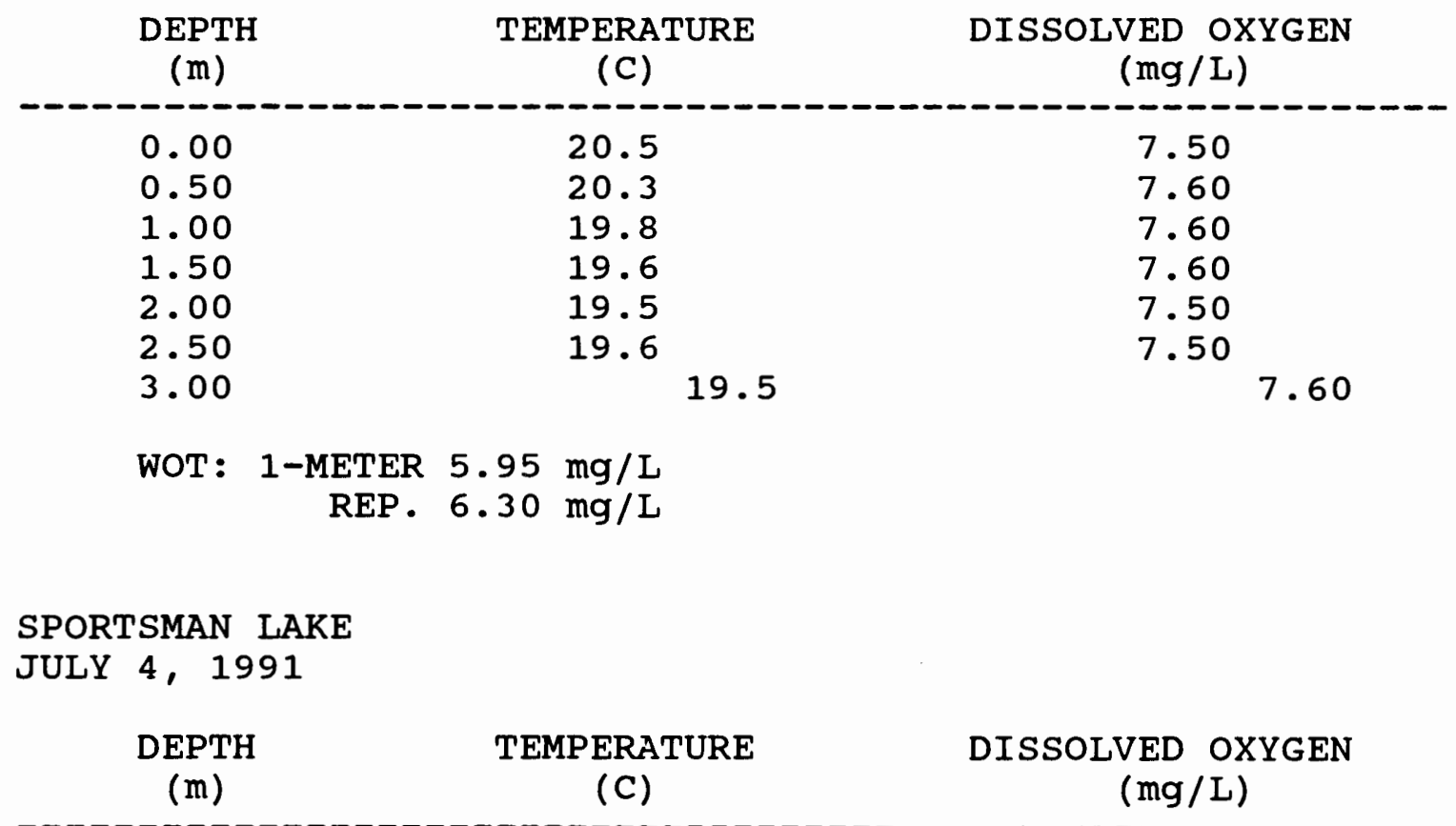




$\begin{array}{lll}0.00 & 21.5 & 8.30 \\ 0.25 & 21.0 & 8.40 \\ 0.50 & 19.6 & 8.50 \\ 0.75 & 19.1 & 8.50 \\ 1.00 & 18.7 & 8.50 \\ 1.25 & 18.5 & 8.40\end{array}$

SPORTSMAN LAKE

AUGUST 19, 1991

\begin{tabular}{ccc}
$\begin{array}{c}\text { DEPTH } \\
(\mathrm{m})\end{array}$ & $\begin{array}{c}\text { TEMPERATURE } \\
(\mathrm{C})\end{array}$ & $\begin{array}{c}\text { DISSOLVED OXYGEN } \\
(\mathrm{mg} / \mathrm{L})\end{array}$ \\
\hline 0.00 & 24.0 & 6.70 \\
0.25 & 23.4 & 6.60 \\
0.50 & 22.1 & 6.95 \\
0.75 & 21.8 & 6.98 \\
1.00 & 21.8 & 6.90 \\
1.25 & 21.6 & 7.31 \\
1.50 & 21.6 & 7.40
\end{tabular}

WOT: 1-METER $7.65 \mathrm{mg} / \mathrm{L}$

REP. $6.90 \mathrm{mg} / \mathrm{L}$

SPORTSMAN LAKE

JULY 25, 1992

\begin{tabular}{ccc}
$\begin{array}{c}\text { DEPTH } \\
(\mathrm{m})\end{array}$ & $\begin{array}{c}\text { TEMPERATURE } \\
(\mathrm{C})\end{array}$ & $\begin{array}{c}\text { DISSOLVED OXYGEN } \\
(\mathrm{mg} / \mathrm{L})\end{array}$ \\
\hline 0.00 & 22.0 & 6.40 \\
0.25 & 21.3 & 6.40 \\
0.50 & 19.3 & 6.40 \\
0.75 & 18.8 & 6.20 \\
1.00 & 18.5 & 6.40 \\
1.25 & 18.6 & 6.70
\end{tabular}

WOT: 1-METER $5.50 \mathrm{mg} / \mathrm{L}$

REP. $6.05 \mathrm{mg} / \mathrm{L}$ 


\section{APPENDIX C}

\section{PHYTOPLANKTON DATA}

This phytoplankton analysis was performed by Jim Sweet, Aquatic Analysts Inc. 
APPENDIX C

\title{
PHYTOPLANKTON SAMPLE ANALYSIS
}

\author{
SAMPLE: Cripple Creek Lake, 0-1 meter
}

SAMPLE DATE: 91-07-07

TOTAL DENSITY $(\# / \mathrm{ml}): 2053$

TOTAL BIOVOLUME (cu. UM/ml): 488225

TROPHIC STATE INDEX: 44.7

DIVERSITY INDEX: 2.78

SPECIES

\section{Rhodomonas minuta}

Fragilaria construens venter

Melosira ambigua

Fragilaria construens

Fragilaria pinnata

Melosira sp.

Scenedesmus sp.

Cymbella minuta

Fragilaria capucina

Scenedesmus denticulatus

Epithemia sorex

Selenastrum sp.

Achnanthes lanceolata

Cyclotella stelligera

Cosmarium sp.

Navicula minima

Melosira italica

Navicula cryptocephala

Unidentified flagellate

Nitzschia sp.

Synedra radians

Nitzschia sp.

\begin{tabular}{rrrr} 
DENSITY & PCT & BIOVOL & PCT \\
\hline 791 & 38.5 & 15819 & 3.2 \\
623 & 30.3 & 84880 & 17.4 \\
135 & 6.6 & 178414 & 36.5 \\
84 & 4.1 & 35811 & 7.3 \\
67 & 3.3 & 12116 & 2.5 \\
50 & 2.5 & 50485 & 10.3 \\
34 & 1.6 & 5049 & 1.0 \\
34 & 1.6 & 12453 & 2.6 \\
17 & 0.8 & 17165 & 3.5 \\
17 & 0.8 & 3029 & 0.6 \\
17 & 0.8 & 19184 & 3.9 \\
17 & 0.8 & 337 & 0.1 \\
17 & 0.8 & 3029 & 0.6 \\
17 & 0.8 & 926 & 0.2 \\
17 & 0.8 & 3534 & 0.7 \\
17 & 0.8 & 740 & 0.2 \\
17 & 0.8 & 31705 & 6.5 \\
17 & 0.8 & 3113 & 0.6 \\
17 & 0.8 & 340 & 0.1 \\
17 & 0.8 & 2019 & 0.4 \\
17 & 0.8 & 6058 & 1.2 \\
17 & 0.8 & 2019 & 0.4
\end{tabular}

SAMPLE: Cripple Creek Lake, 0-.75 meters

SAMPLE DATE: $91-08-21$

TOTAL DENSITY (\#/ml): 531

TOTAL BIOVOLUME (cu. UM/ml): 21129

TROPHIC STATE INDEX: 22.3

DIVERSITY INDEX: 1.54

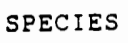

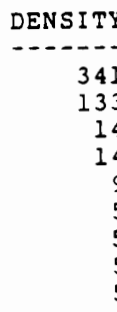

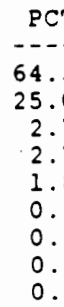

PCT

BIOVOL

6822

7296

355

284

2047

95

1540

2463

227
PCT

32.3

34.5

1. 7

1. 3

0.4

7.3

11.7 
PHYTOPLANKTON SAMPLE ANALYSIS

SAMPLE: AnVIl, $0-1$

SAMPLE DATE: 91-07-08

TOTAL DENSITY $(\# / \mathrm{ml}): 543$

TOTAL BIOVOLUME (cu.uM/ml): 56865

TROPHIC STATE INDEX: 29.3

DIVERSITY INDEX: 1.75

SPECIES

ochromonas-like

Mallomonas-like

Mallomonas sp.

Chromulina sp.

Unidentified flagellate

Chl amydomonas sp.

Anabaena flos-aquae

Cymbella microcephala

Tetraedron caudatum

pediastrum tetras

oocystis lacustris

Achnanthes minutissima

Gymnodinium sp.

Tetraedron minimum

Eunotia pectinalis

\begin{tabular}{rrrr} 
DENSITY & PCT & BIOVOL & PCT \\
\hline 388 & 71.4 & 17458 & 30.7 \\
58 & 10.7 & 5237 & 9.2 \\
19 & 3.6 & 7371 & 13.0 \\
15 & 2.7 & 291 & 0.5 \\
15 & 2.7 & 291 & 0.5 \\
5 & 0.9 & 1576 & 2.8 \\
5 & 0.9 & 4849 & 8.5 \\
5 & 0.9 & 257 & 0.5 \\
5 & 0.9 & 194 & 0.3 \\
5 & 0.9 & 145 & 0.3 \\
5 & 0.9 & 1494 & 2.6 \\
5 & 0.9 & 242 & 0.4 \\
5 & 0.9 & 13094 & 23.0 \\
5 & 0.9 & 873 & 1.5 \\
5 & 0.9 & 3492 & 6.1
\end{tabular}

PHYTORLANKTON SAMPLE ANALYSIS

SAMPLE: Anvil, $0.5-1$

SAMPLE DATE: $91-08-22$

TOTAL DENSITY $(\# / \mathrm{ml}): 1424$

TOTAL BIOVOLUME (cu.uM/ml): 185991

TROPHIC STATE INDEX: 37.7

DIVERSITY INDEX : 1.79
PCT

- ---

22.5

2.5

2.5

2. 5

1. 7

1.7

0.8

0.8

0.8

0.8

0.8
BIOVOL

17803

13058

1602

11572

5683

9020

2908

5697

116311

1009

320

1009
PCT

9.6

7.0

0.9

6.2

3.1

4. 8

1. 6

3.1

62.5

0.5

0.5

0.2 
PHYTOPLANKTON SAMPLE ANALYSIS

SAMPLE: Beaver Pond, 1.25-2.5

SAMPLE DATE: 91-06-24

TOTAL DENSITY $(\# / m i): 2419$

TOTAL BIOVOLUME (cu. UM/ml): 113283

TROPHIC STATE INDEX: 34.2

EIVERSITI INDEX: 1.03

SPECIES

Rhodomonas minuta

Chromulina sp.

Ankistrodesmus falcatus

Kephyrion sp.

Cryptomonas erosa

Chrysococcus rufescens

Trachelomonas volvocina

Unidentified flagellate

Mallomonas-like

\begin{tabular}{rr} 
DENSITY & PCT \\
\hline 2050 & 84.7 \\
123 & 5.1 \\
62 & 2.5 \\
41 & 1.7 \\
41 & 1.7 \\
41 & 1.7 \\
21 & 0.8 \\
21 & 0.8 \\
21 & 0.8
\end{tabular}

\section{PHYTOPLANKTON SAMPLE ANALYSIS}

SAMPLE: Beaver Pond, 2 meters

SAMPLE DATE: $91-08-23$

TOTAL DENSITY $(\# / \mathrm{ml}): 2147$

TOTAL BIOVOLUME (cu.uM/ml): 847609

TROPHIC STATE INDEX: 48.7

DIVERSITY INDEX: 2.70

SPECIES

Cryptomonas erosa

Ankistrodesmus falcatus

Rhodomonas minuta

Phacus sp.

Chlamydomonas sp.

Sphaerocystis schroeteri

Gymnodinium sp.

Ochromonas sp.

Chroomonas sp.

Trachelomonas sp.

Cocconeis placentula

Peridinium cinctum

$\mathrm{Nitzschia} \mathrm{acicularis}$

Dictyosphaerium ehrenbergianum

Trachelomonas volvocina

Dinobryon sp.

DENSITY
884
451
235
198
72
72
36
36
36
18
18
18
18
18
18
18

$2=5$

41.2

41.2
21.0

10.9

9.2

9.2

3.4

3. 4

1. 7

1. 7

1.7
1.7

0.8

0.8

0.8

0.8

0.8

0.8

0.8 459659

11275

4690

69454

23452

12628

97416

3067

2345

36080

8298

75768

5051

2165

34005

2255

PCT

54.2

1. 3

0.6

8.2

2.8

1.5

11.5

0.4

0.3

4.3

1.0

8.9

0.6

0.3

4.0

0.3 


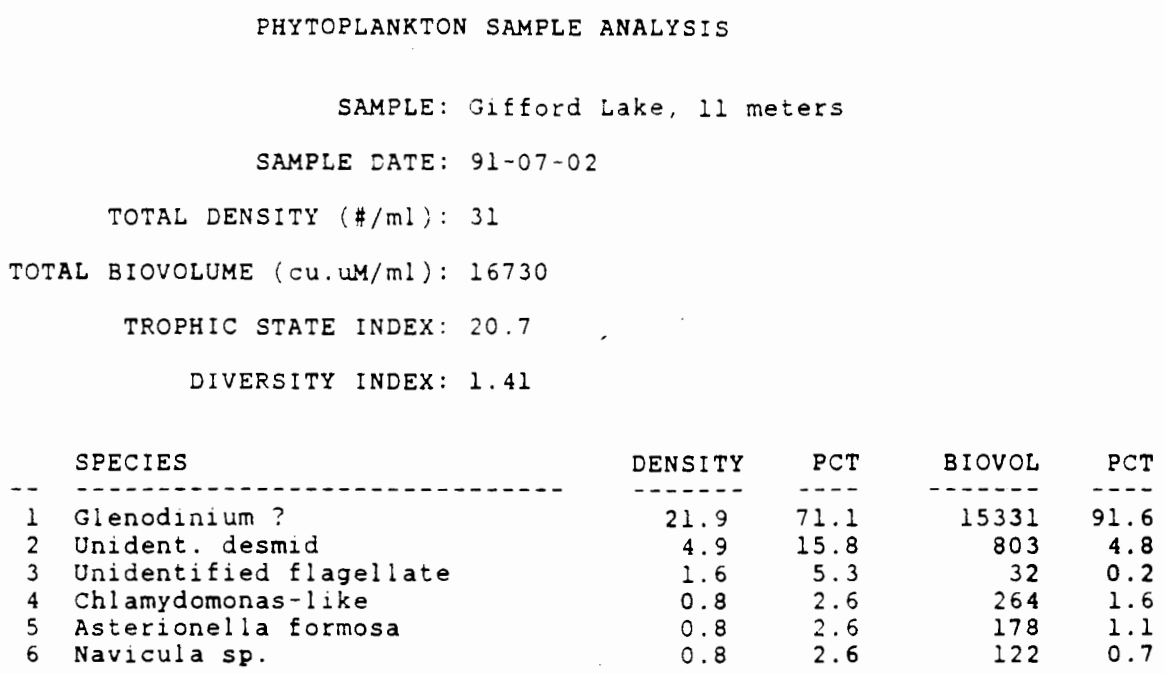

PHYTOPLANKTON SAMPLE ANALYSIS

SAMPLE: Gifford Lake, 11 meters

SAMPLE DATE: 91-08-29

TOTAL DENSITY (\#/ml): 627

TOTAL BIOVOLUME (cu.uM/ml): 20143

TROPHIC STATE INDEX: 22

DIVERSITY INDEX: 0.43

\begin{tabular}{rlrrrr} 
& SPECIES & DENSITY & PCT & BIOVOL & PCT \\
\hline 1 & Chromulina sp. & 58 & 93.8 & 11765 & 58.4 \\
2 & Oocystis pusilia & 25 & 3.9 & 4235 & 21.0 \\
3 & Mallomonas sp. & 5 & 0.8 & 1863 & 9.2 \\
4 & Chlamydomonas-like & 5 & 0.8 & 1593 & 7.9 \\
5 & Sphaerocystis schroeteri & 5 & 0.8 & 686 & 3.4
\end{tabular}


PHYTOPLANKTON SAMPLE ANALYSIS

SAMPLE: Monon, 10 meters

SAMPLE DATE: 91-06-29

TOTAL DENSITY $(\# / \mathrm{ml}): 164$

TOTAL BIOVOLUME (cL.UM/ml): 8445

TROPHIC STATE INDEX: 16.2

DIVERSITY INDEX : 1.65

SPECIES

\begin{tabular}{rrrr} 
DENSITY & PCT & BIOVOL & PCT \\
\hline 102 & 62.2 & 2038 & 24.1 \\
38 & 23.5 & 768 & 9.1 \\
10 & 6.1 & 3257 & 38.6 \\
5 & 3.1 & 100 & 1.2 \\
2 & 1.0 & 301 & 3.6 \\
2 & 1.0 & 361 & 4.3 \\
2 & 1.0 & 869 & 10.3 \\
2 & 1.0 & 501 & 5.9 \\
2 & 1.0 & 251 & 3.0
\end{tabular}

PHYTORLANKTON SAMPLE ANALYSIS

SAMPLE: Monon, 8 meters

SAMPLE DATE: 91-09-01

TOTAL DENSITY $(\# / \mathrm{ml}): 613$

TOTAL BIOVOLUME (cu. UM/ml): 42037

TROPHIC STATE INDEX: 27.1

DIVERSITY INDEX : 0.46

\begin{tabular}{llrrrr} 
& SPECIES & DENSITY & PCT & BIOVOL & PCT \\
\hline 1 & Chromulina sp. & 553 & 90.3 & 11062 & 26.3 \\
2 Cryptomonas erosa & 60 & 9.7 & 30974 & 73.7
\end{tabular}




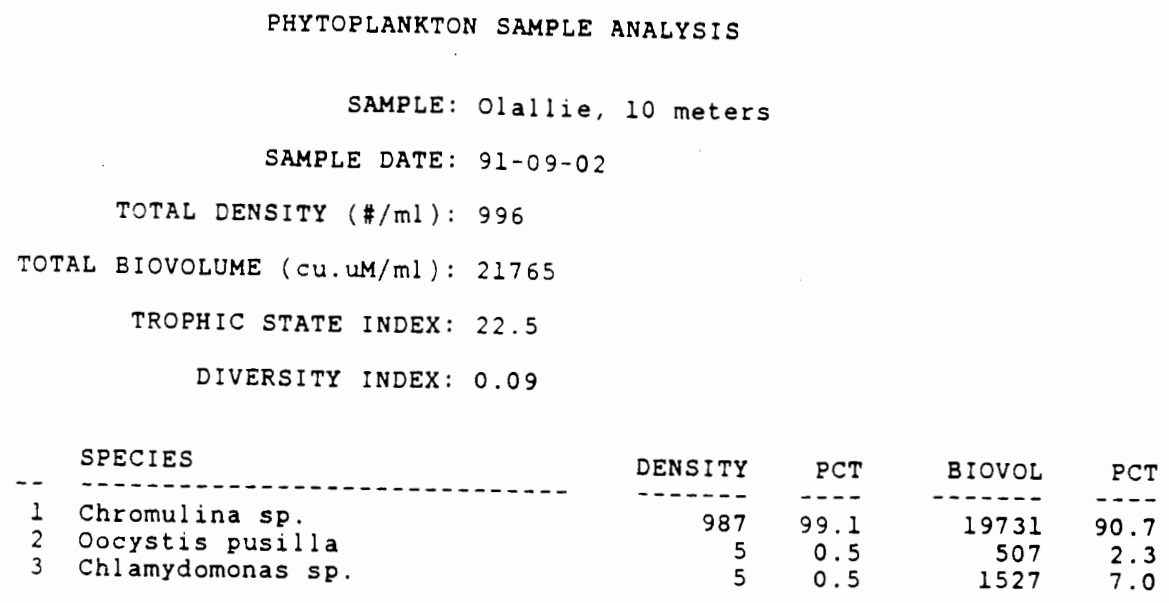

PHYTOPLANKTON SAMPLE ANALYSIS

SAMPLE: Olallie, $0-12$

SAMPLE DATE: $91-06-30$

TOTAL DENSITY $(\# / \mathrm{ml}): 81$

TOTAL BIOVOLUME (cu. uM/ml): 26025

TROPHIC STATE. INDEX: 23.8

DIVERSITY INDEX : 1.97

SPECIES

- - - - - - - - - -

Chromulina sp.

Oocystis pusilla

Chl amydomonas sp.

Gymnodinium sp.

Sphaerocystis schroeteri

Tetraedron sp.

Unidentified flagellate

Achnanthes minutissima

Crucigenia quadrata

cryptomonas erosa

\begin{tabular}{rr} 
DENSITY & PCT \\
\hdashline 48.5 & 60.2 \\
11.0 & 13.6 \\
7.0 & 8.7 \\
7.0 & 8.7 \\
1.6 & 1.9 \\
1.6 & 1.9 \\
1.6 & 1.9 \\
0.8 & 1.0 \\
0.8 & 1.0 \\
0.8 & 1.0
\end{tabular}

$\begin{array}{rr}\text { BIOVOL } & \text { PCT } \\ -971 & 3.7 \\ 2622 & 10.1 \\ 2290 & 8.8 \\ 19027 & 73.1 \\ 329 & 1.3 \\ 42 & 0.2 \\ 31 & 0.1 \\ 39 & 0.2 \\ 266 & 1.0 \\ 407 & 1.6\end{array}$


PHYTOPLANKTON SAMPLE ANALYSIS

SAMPLE: Fish, 12 meters

SAMPLE DATE: 91-07-01

TOTAL DENSITY $(\# / \mathrm{ml}): 7547$

TOTAL BIOVOLUME (cu. UM/ml): 2731256

TROPHIC STATE INDEX: 57.1

DIVERSITY INDEX: 1.17

- -2

Asterionella formosa

Chrysochromul ina sp.

Cyclotella stelligera

6013

872

Selenastrum minutum

Rhodomonas minuta

Chlamydomonas sp.

Unidentified flagellate

Crucigenia quadrata

Achnanthes clevei

Cryptomonas erosa

BIOVOL PCT 2645867

17439

9922

2405

2405

29315

1203

2556

4510

15635

26.9

96.9
0.6

0.4

0.1

0.1

1.1

0.0

0.1

0.2

0.6

PHYTOPLANKTON SAMPLE ANALYSIS

SAMPLE: Fish, 7 meters

SAMPLE DATE: $91-08-30$

TOTAL DENSITY $(\# / \mathrm{ml}): 356$

TOTAL BIOVOLUME (cu. UM/ml): 80722

TROPHIC STATE INDEX: 31.8

DIVERSITY INDEX: 2.43

\section{SPECIES}

DENSITY

\section{Melosira distans}

Chromulina sp.

Oocystis pusilla

Crucigenia quadrata

Botryococcus braunil

Rhodomonas minuta

Asterionella formosa

Ankistrodesmus falcatus

Sphaerocystis schroeteri

Eragilaria construens 


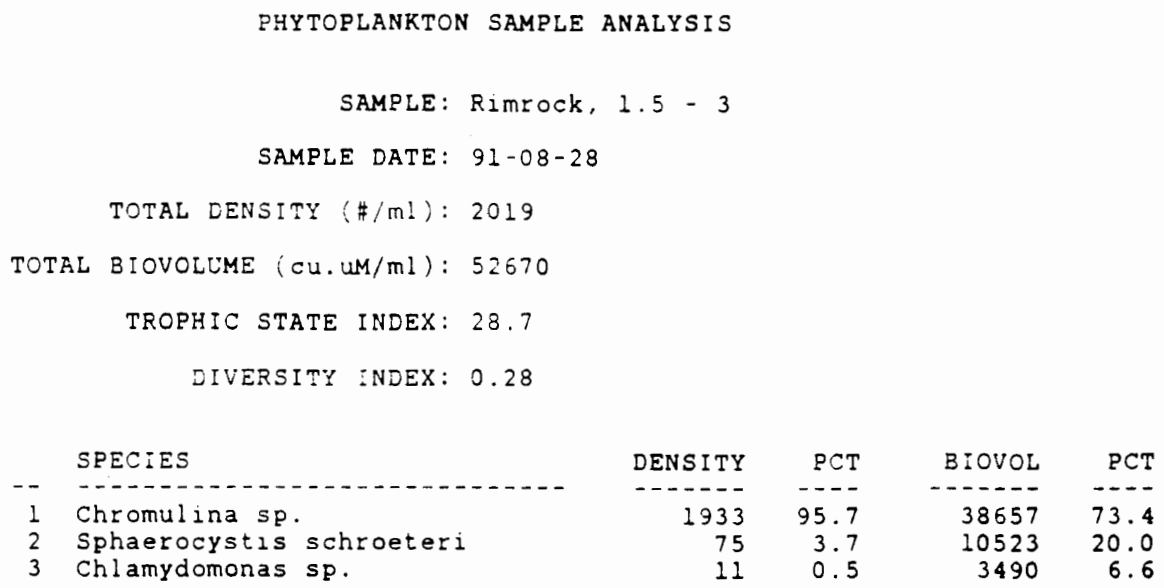

PHYTORLANKTON SAMPLE ANALYSIS

SAMPLE: Rimrock, $1.5-3$

SAMPLE DATE: 91-07-02

TOTAL DENSITY $(\# / \mathrm{mL}): 334$

TOTAL BIOVOLUME (cu.uM/ml): 8562

TROPHIC STATE INDEX: 16.3

DIVERSITY INDEX: 0.12

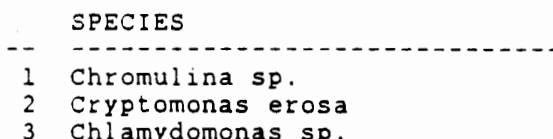

$\begin{array}{rrrr}\text { DENSITY } & \text { PCT } & \text { BIOVOL } & \text { PCT } \\ -329 & 98.6 & 6577 & 76.8 \\ 2 & 0.7 & 1221 & 14.3 \\ 2 & 0.7 & 763 & 8.9\end{array}$


PHYTOPLANKTON SAMPLE ANALYSIS

SAMPLE: Round, $0-6$ meters

SAMPLE DATE: 91-07-08

TOTAL DENSITY (\#/ml): 1935

TOTAL BIOVOLUME (cu. UM/ml): 912300

TROPHIC STATE INDEX: 49.2

DIVERSITY INDEX: 1.56

\section{SPECIES}

Asterionella formosa

Chl amydomonas sp.

Rhodomonas minuta

Chromulina sp.

Unidentified flagellate

Cocconeis placentula

cchromonas sp.

Melosira italica

Peridinium cinctum

Gomphonema angustatum

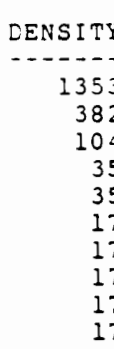

PCT

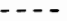

69.5

13.6

0.2

0.1

0.1

0.9

0.2

7.2

8.0

0.3

PHYTOPLANKTON SAMPLE ANALYSIS

SAMPLE: Round, 6 meters

SAMPLE DATE: $91-08-24$

TOTAL DENSITY $(\# / \mathrm{ml}): 14 \$ 3$

TOTAL BIOVOLUME (cu. UM/ml): 247629

TROPHIC STATE INDEX: 33.8

DIVERSITY INDEX: 2.62

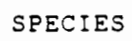

DENS I TY
812
438
90
64
13
13
13

\begin{tabular}{rrr} 
PCT & BIOVOL & PCT \\
\hline 56.2 & -100095 & -10.4 \\
30.4 & 99277 & 40.1 \\
6.2 & 1804 & 0.7 \\
4.5 & 33503 & 13.5 \\
0.9 & 4188 & 1.7 \\
0.9 & 6958 & 2.8 \\
0.9 & 1804 & 0.7
\end{tabular}


PHYTOPLANKTON SAMPLE ANALYSIS

SAMPLE: Sportsman, $0-1.5$

SAMPLE DATE: 91-07-04

TOTAL DENSITY $(\# / \mathrm{ml}): 547$

TOTAL BIOVOLUME (cu. UM/mi): 35747

TROPHIC STATE INDEX: 26

DIVERSITY INDEX: 2.07

SPECIES

Chromulina sp.

Unidentified flagel late

Chlamydomonas sp.

Cocystis pusilla

Mal I omonas-like

synedra cyclopum

Ankistrodesmus falcatus

Sphaerocystis schroeteri

Rhodomonas minuta

Nitzschia paleacea

Tetraedron minimum

Gomphonema sp.

Cryptomonas erosa

Fragilaria construens venter

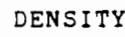

PCT
.---
50.0
32.5
2.5
2.5
1.7
1.7
1.7
1.7
1.7
0.8
0.8
0.8
0.8
0.8

BIOVOL

PCT

15.3

9.9

12.4

6.2

2.3

21.5

0.6

17.8

0.5

1. 2

2.3

2. 5

6.6

0.6

\section{PHYTOPLANKTON SAMPLE ANALYSIS}

SAMPLE: Sportsman, 1 meter

SAMPLE DATE: $31-08-19$

TOTAL DENSITY $(\# / \mathrm{ml}): 902$

TOTAL BIOVOLUME (cu. UM/ml): 54612

TROPHIC STATE INDEX: 29

DIVERSITY INDEX: 1.80
SPECIES

Ankistrodesmus falcatus

Chromulina sp.

Cryptomonas erosa

Rhodomonas minuta

Mallomonas-like

Unidentified flagellate

Gomphonema angustatum

Chlamydomonas sp.

\begin{tabular}{r} 
DENS ITY \\
\hdashline 467 \\
287 \\
57 \\
41 \\
25 \\
8 \\
8 \\
8
\end{tabular}

\begin{tabular}{r} 
PCT \\
\hdashline 51.8 \\
31.8 \\
6.4 \\
4.5 \\
2.7 \\
0.9 \\
0.9 \\
0.9
\end{tabular}

\begin{tabular}{r} 
BIOVOL \\
\hline 11685 \\
5740 \\
29848 \\
820 \\
2214 \\
164 \\
1476 \\
2665
\end{tabular}

PCT

21.4

10.5

54.7

1.5

4.1

0.3

2.7

4.9 


\section{APPENDIX D}

\section{ZOOPLANKTON DATA}

This zooplankton analysis was performed by Allan vogel, ZP Taxonomic services. 
ZOOPLANKTON DATA

ANVIL LAKE--7/8/91

$\underline{\text { SPECIES }}$ (Individuals $/ \mathrm{m}^{3}$ )

Daphnia rosea

Ceriodaphnia reticulata

Bosmina longirostris

Chydorus sphaericus

Diaptomus novamexicanus

Diaptomus kenai

Diaptomus copepodite

Cyclops vernalis

Cyclopoid copepodites

copepod nauplii

Epiphanes spp.

Kellicattia longispina

Keratella cochlearis

Polyarthra dolichoptera

P. vulgaris

water mite

TOTAL DENSITY
191

64

159

32

350

191

223

127

32

1019

32

255

414

4043

95

64

7289

ANVIL LAKE--8/22/91

SPECIES

DENSITY (Individuals $/ \mathrm{m}^{3}$ ) 
Daphnia rosea $\quad 272$

Ceriodaphnia reticulata 8964

Diaphanosoma brach. $\quad 598$

Bosmina longirostris $\quad 217$

Chydorus sphaericus 109

A. guttata 54

Diaptomus novamexicanus 2553

D. kenai $\quad 5378$

D. copepodite 2716

Cyclops vernalis $\quad 217$

Cyclopoid copepodites 109

Copepod nauplii 1358

Cypridopsis vidue $\quad 54$

Polyartha dolichoptera $\quad 272$

TOTAL DENSITY 22871

BEAVER POND LAKE--6/24/91

SPECIES

$\underline{\text { DENSITY }}$ (Individuals $/ \mathrm{m}^{3}$ )

Daphnia pulex

2037

Diaptomus kenai

5949

D. copepodite

20290

Copepod naulii

7823

Keratella quadrata

81

TOTAL DENSITY 
BEAVER POND LAKE--8/23/91

Daphnia pulex

782

Ceriodaphnia pulchella

16

Diaptomus kenai

1010

D. copepodite

839

Cyclops vernalis

8

Cyclopoid copepodites

16

Copepod nauplii

2053

Cypridopsis vidua

41

Polyartha dolichoptera

8

Chaoborus

440

Water mite

16

TOTAL DENSITY

5240

CRIPPLE CREEK LAKE--7/7/91

SPECIES

DENSITY (Individual $/ \mathrm{m}^{3}$ )

Daphnia rosea

95

Bosmina longirostris

509

Chydorus sphaericus

64

Alona quadrangularis

32

Diaptomus tyrrelli

223

D. kenai

509

D. copepodite

1019

Cyclops vernalis

64

Cyclopoid copepodites

64 
Copepod nauplii $\quad 414$

Keratella cochlearis $\quad 64$

Polyartha dolichoptera $\quad 64$

TOTAL DENSITY 3119

CRIPPLE CREEK LAKE--8/21/91

SPECIES

DENSITY (Individual $/ \mathrm{m}^{3}$ )

Daphnia rosea $\quad 102$

Ceriodaphnia pulchella 25

Diaphanosoma brach. $\quad 25$

Bosmina longirostris 102

Alona quadranqularis $\quad 25$

Diaptomus tyrrel1i 1401

D. kenai 1044

D. copepodite 5297

Epischura nevadensis 25

E. nevadensis copepodites 51

Copepod nauplii 2343

Conochilus spp. $\quad 1375$

Filinia terminalis $\quad 76$

Kellicottia longispina $\quad 127$

Keratella cochlearis $\quad 153$

K. quadrata

Chironomid larvae $\quad 25$

$\begin{array}{lr}\text { TOTAL DENSITY } & 12249\end{array}$ 


\section{FISH LAKE--7/7/91}

Daphnia rosea

Eubosmina hagmanni

Holopedium gibberum

420

Diaptomus tyrrelli

83

D. kenai

3

D. copepodite

89

Epischura nevadensis

54

E. nevadensis copepodites

16

Cyclops bicuspidatus thomasi

172

Cyclopoid copepodites

1467

Copepod nauplii

83

Conochilus spp.

691

Kellicottia longispina

22

TOTAL DENSITY

3282

FISH LAKE--8/8/91

Daphnia rosea

98

Eubosmina hagmanni

33

Holopedium qibberum

456

Diaptomus tyrrelli

228

Diaptomus kenai

130

D. copepodite

196

Cyclops bicuspidatus thomasi 
Copepod nauplii

65

Conochilus spp.

65

Kellicottia longispina

TOTAL DENSITY

$$
\text { GIFFORD LAKE--7/2/91 }
$$

SPECIES

DENSITY (Individuals $/ \mathrm{m}^{3}$ )

Daphnia rosea

13

Eubosmina hagmanni

407

Holopedium gibberum

363

Diaptomus copepodite

6

Epischura nevadensis

38

E. nevadensis copepodites

64

cyclops bicuspidatus thomasi

Cyclopoid copepodites

1120

copepod nauplii

45

Conochilus spp.

Kellicottia longispina

Keratella cochlearis

6

TOTAL DENSITY

Daphnia rosea

Eubosmanni hagmanni

Holopedium qibberum 
Eubosmanni hagmanni

665

Holopedium gibberum 933

Diaptomus signicauda $\quad 26$

Diaptomus copepodite $\quad 141$

$\begin{array}{ll}\text { Epischura nevadensis } & 77\end{array}$

E. nevadensis copepodites 882

Cyclops bicuspidatus thomasi 1508

$\begin{array}{ll}\text { Cyclopoid copepodites } & 1163\end{array}$

Copepod nauplii 64

Conochilus spp. $\quad 64$

Keratella cochlearis 205

Polyartha dolichoptera $\quad 38$

TOTAL DENSITY 5829

MONON LAKE--6/29/91

Daphnia galeata mendotae $\quad 64$

Eubosmina hagmanni $\quad 484$

Holopedium gibberum 166

Diaptomus copepodite 51

Epischura nevadensis $\quad 76$

E. nevadensis copepodites 38

Cyclops bicuspidatus thomasi 388

Cyclopoid copepodites 1502

Copepod nauplii 95

Polyartha dolichoptera $\quad 64$ 
MONON LAKE--9/1/91

Daphnia galeata mendotae

7349

D. rosea

731

Eubosmina hagmanni

138

Holopedium gibberum

494

Diaptomus signicauda

119

D. copepodite

20

Epistura nevadensis

E. nevadensis copepodites

336

Cyclops bicuspidatus thomasi

99

Cyclopoid copepodites

948

Brachionus spp.

20

Kellicottia longispina

59

Polyartha dolichoptera

454

TOTAL DENSITY

10984

OLLALIE LAKE--6/30/91

Daphnia rosea

13

Eubosmina hagmanni

1019

Holopedium gibberum

1642

Diaptomus kenai

382

Epischura nevadensis

38

E. nevadensis copepodites

191

Cyclops bicuspidatus thomasi

407

Cyclopoid copepodites

2508 
Copepod nauplii

Kellicottia bostonensis

TOTAL DENSITY

6277

$$
\text { OLLALIE LAKE--9/2/91 }
$$

Daphnia geleata mendotae 1047

D. rosea 109

Eubosmina hagmanni 1531

Holopedium gibberum 1679

Diaptomus kenai

89

Epischura nevadensis

49

E. nevadensis copepodites

533

Cyclopoid copepodites

30

Copepod nauplii

49

Kellicottia bostonensis

10

polyartha dolichoptera

247

Synchaeta spp.

10

TOTAL DENSITY

5383

RIMROCK LAKE--7/3/91

Eubosmina hagmanni

21

Holopedium gibberum

7979

Diaptomus kenai

Diaptomus copepodite

42

Copepod nauplii 
Asplanchna priodonta

TOTAL DENSITY
42

9125

RIMROCK LAKE--8/30/91

Eubosmina hagmanni

Holopedium gibberum

Chydorus sphaericus

Alona guttata

Diaptomus signicauda

D. copepodite

Epischura nevadensis

E. nevadensis copepodites

Copepod nauplii

Conochilus spp.

Keratella cochlearis

TOTAL DENSITY
158

5546

26

26

631

53

499

841

26

5967

26

13800

$$
\text { ROUND LAKE--7/8/91 }
$$

Daphnia rosea

Daphnia pulex

Bosmina longirostris

Holopedium gibberum

Diaptomus copepodite

Epischura nevadensis

E. nevadensis copepodites
196

64

85

74

5

5 
Cyclops bicuspidatus thomasi 223

Cyclopoid copepodites 133

$\begin{array}{lr}\text { Copepod nauplii } & 122\end{array}$

Conochilus spp. $\quad 11$

Kellicottia longispina 5

Keratella cochlearis $\quad 101$

K. quadrata $\quad 244$

Polyartha dolichoptera 5

Unidentified spp. 5

$\begin{array}{lr}\text { TOTAL DENSITY } & 1427\end{array}$

$$
\text { ROUND LAKE--8/24/91 }
$$

Daphnia pulex

5161

Bosmina longirostris $\quad 14$

Holopedium gibberum $\quad 27$

Diaptomus kenai $\quad 14$

Cyclops bicuspidatus thomasi 475

Cyclopoid copepodites 177

Copepod nauplii 367

Kellicottia longispina $\quad 14$

$\begin{array}{ll}\text { Nematode } & 14\end{array}$

$\begin{array}{ll}\text { TOTAL DENSITY } & 6261\end{array}$

$$
\text { SPORTSMAN--7/4/91 }
$$

Daphnia rosea $\quad 2292$

Chydorus sphaericus $\quad 85$ 
Diaptomus signicauda

D. kenai

870

D. copepodite

3565

Cyclops vernalis

21

Copepod nauplii

3608

Keratella cochlearis

1167

TOTAL DENSITY

11735

$$
\text { SPORTSMAN--8/19/91 }
$$

Daphnia rosea

1467

Daphnia reticulata

163

Diaphanasoma brach.

2879

Eubosmina hagmanni

109

Chydorus sphaericus

163

Alona affinis

217

Pleuroxus denticulatus

163

Sida crystallina

109

Diaptomus signicauda

9453

D. kenai

1467

D. copepodite

8855

Cyclops vernalis

869

Cyclopoid copepodites

380

Copepod nauplii

435

Cypridopsis vidua

54

Keratella cochlearis

oligochaete 
Hydra

TOTAL DENSITY

28303 